Florida International University FIU Digital Commons

\title{
The Gender Problem of Buddhist Nationalism in Myanmar: The 969 Movement and Theravada Nuns
}

Grisel d'Elena

Florida International University, goliv036@fiu.edu

DOI: $10.25148 /$ etd.FIDC000261

Follow this and additional works at: https://digitalcommons.fiu.edu/etd

Part of the Asian History Commons, Asian Studies Commons, Buddhist Studies Commons, Community-Based Research Commons, Ethics in Religion Commons, Ethnic Studies Commons,

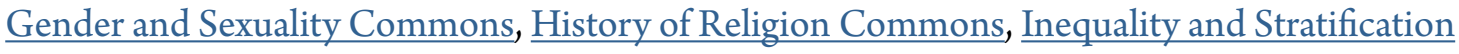
Commons, International Relations Commons, New Religious Movements Commons, Other Feminist, Gender, and Sexuality Studies Commons, Politics and Social Change Commons, Race and

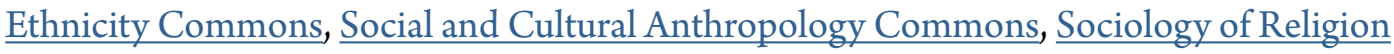
Commons, and the Women's Studies Commons

\section{Recommended Citation}

d'Elena, Grisel, "The Gender Problem of Buddhist Nationalism in Myanmar: The 969 Movement and Theravada Nuns" (2016). FIU Electronic Theses and Dissertations. 2463.

https://digitalcommons.fiu.edu/etd/2463 


\section{FLORIDA INTERNATIONAL UNIVERSITY}

Miami, Florida

THE GENDER PROBLEM OF BUDDHIST NATIONALISM IN MYANMAR:

THE 969 MOVEMENT AND THERAVĀDA NUNS

A thesis submitted in partial fulfillment of

the requirements for the degree of

MASTER OF ARTS

in

RELIGIOUS STUDIES

by

Grisel d'Elena 
To: Dean John F. Stack

Steven J. Green School of International and Public Affairs

This thesis, written by Grisel d'Elena, and entitled The Gender Problem of Buddhist Nationalism in Myanmar: The 969 Movement and Theravāda Nuns, having been approved for style and intellectual content, is referred to you for judgment.

We have read this thesis and recommend that it be approved.

Christine Gudorf

Oren Baruch Stier

Steven M. Vose, Major Professor

Date of Defense: April 1, 2016

This thesis of Grisel d'Elena is approved.

Dean John F. Stack Steven J. Green School of International and Public Affairs

Andrés G. Gil

Vice President for Research and Economic Development and Dean of the University Graduate School

Florida International University, 2016 
(C) Copyright 2016 by Grisel d’Elena

All rights reserved. 


\section{DEDICATION}

To my mother, Elena Aleman, and my sweet son, Jake Lennon Bru. This is not for you. It is because of you. There isn't a graduate course available in this world that could provide the wisdom you both exude every day of your lives. Thank you for teaching me the great gift of unconditional love and empathy. Without it, I could never have made it this far. 


\section{ACKNOWLEDGMENTS}

First and foremost, I owe my mother and son gratitude for the drive that has allowed me to come this far in my studies. They are central to my desire for stability and success. I want to share with them my global perspectives and all the benefits I may reap from learning how to communicate them, as they have shared unconditional and boundless amounts of love, support, sincerity and knowledge with me. Speaking of unconditional, I owe an immense amount of gratitude and respect to my major professor and graduate committee members, Drs. Steven Vose, Oren Stier and Christine Gudorf. Dr. Vose has been so valuable to this project and spent hours explaining theoretical and methodological concepts that were so foreign to me. A highly educated academic has never treated me with such respect, patience, understanding and egalitarian values. I am everything I am academically because of his belief in me and I will never forget it. He has immortalized what it is to be mentor in all aspects of the role. He served as a professor, therapist and life coach through a goal I thought several times I was incapable of achieving. Dr. Vose would do really well financially in a position where clocking in is a requisite, as he works around the clock to ensure that his students truly grasp the concepts of what they have set out to do. Dr. Stier has also played a fundamental role in this project, as he is exactly what I aim to become in terms of providing students with a multidimensional view of religion and violence. His tough love drove me to go beyond the viability of my project funding and limited time frame. Every time I ran into an academic barrier, it was Dr. Stier who pushed me over the hurdle of logistics and barriers. Dr. Gudorf's role was multidimensional in this project as well. Her teaching style is so thorough 
and inspiring. Her multitude of roles as a scholar, professor, feminist and mother consistently inspired me to push harder and play my own roles through grad school with an additional hero to look up to.

Outside of the core members, others helped the completion of this thesis. Professor Erin Weston, who mentored me as a teaching assistant provided so many tools for my success in and out of the academic sphere. Her presence was invaluable and I will never forget every fundamental piece of encouragement she provided both emotionally and academically. Yusimi Sayus and Luz Aviles were also such an important part of this as they always managed to cheer us all up in the department through their beautiful smiles every morning and timely reminders of the tedious paperwork that had to be processed in order to complete this thesis. My research partner, Darbee Hagerty, won a special place in my heart. She played the role of "kid sister" throughout the entire process and took on the feminist portion of this project with such finesse. I learned so much from Darbee about perspective, womanhood, peace and even myself. Dr. Maung Zarni has been a role model, long distance advisor and ever so enlightening figure academically, culturally and spiritually throughout the course of this thesis. His work on the Rohingya as a Burmese-raised Buddhist educated in the United States has provided a perspective I was unable to get from any of my sources in Myanmar. His activism for the human rights of the Rohingya is central to my work and driving force that inspired me to focus on this topic. Dr. Michael Jerryson served as my academic rockstar throughout this process as I was exposed to his work, along with that of Dr. Mark Juergensmeyer, on Buddhist violence in Southeast Asia as an undergraduate. Having his long distance support was 
one of the greatest motivations throughout this project. I also appreciate the opportunity granted to me to present my work on his religion and violence panel at the national meeting of the AAR in 2015. His theoretical advice and research is what planted the seed for this project. Professor Hiroko Kawanami’s feminist contributions to Myanmar's nun community are what inspired me to explore the rhetoric of protecting women. It was because of her that I was so well connected in Myanmar and I am eternally grateful for the head start and friendships she provided access to.

Finally, great thanks go to my Myanmar family, U Panna Jota, Daw Nang and the nuns at Thila Nyunt, who allowed me to shadow their lives and discuss such personal and controversial topics, knowing the possibilities that may come from their publication. I fully understand what a great risk it is to reveal one's authentic self to a stranger and my gratitude for this opportunity is endless. Without them, I could have never been able to truly grasp this entire experience and the regime's effect on its people. 


\section{ABSTRACT OF THE THESIS \\ THE GENDER PROBLEM OF BUDDHIST NATIONALISM IN MYANMAR: THE 969 MOVEMENT AND THERAVĀDA NUNS \\ by}

Grisel d'Elena

Florida International University, 2016

Miami, Florida

\section{Professor Steven M. Vose, Major Professor}

This thesis uses transnational and Black feminist frameworks to analyze Buddhist nationalist discourses of gender and violence against religious and ethnic minorities in Myanmar. Burmese Buddhist nationalists’ marginalization of the Muslim Rohingya ethnic minority is inextricably linked to their attempts to control Buddhist women. Research includes interviews with U Ashin Wirathu, the leader of the monastic-led nationalist group, the 969 Movement, and with other monks of the organization, as well as with non-nationalist monks, nuns and laywomen. I also analyze Theravada textual discourse as read by my subjects in light of the history of Myanmar to understand the ways the local Theravada tradition has marginalized women and non-Buddhists. By connecting the lack of bhikkhuni ordination and laws hindering Buddhist women from marrying non-Buddhist men with the portrayal of the Rohingya as a threat to the nation, I show how Buddhist nationalists attempt to consolidate power and forestall the democratization process. 


\section{TABLE OF CONTENTS}

CHAPTER PAGE

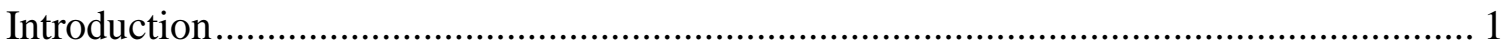

Chapter Outline ....................................................................................................... 5

A Note on the Use of the Names Burma and Myanmar .............................................. 7

1. Myanmar's Saya-leis: Betwixt and Between This Worldly and Other Worldly

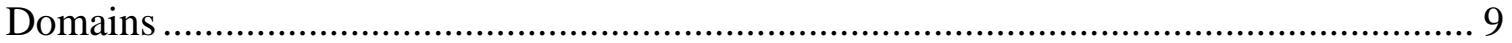

A Brief Historical Background of Women in Theravāda Buddhism.......................... 10

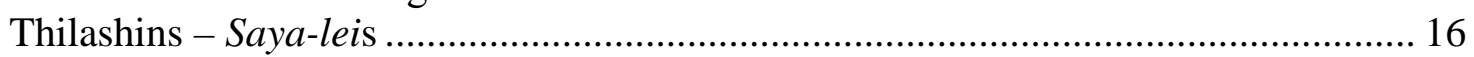

Daw Nang and the Nuns of Thila Nyunt and Sakyadhita Nunneries ......................... 21

The Curse of Womanhood within Buddhism in Myanmar.......................................... 31

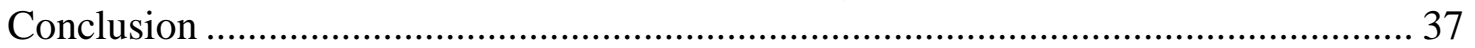

2. The Paradox of Ordination and Religious Nationalism: Theravāda Buddhist Female

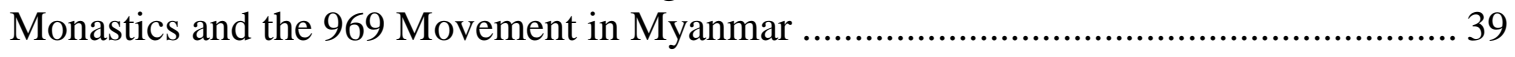

The 969 Movement-From Outlaws to Cronies ..................................................... 41

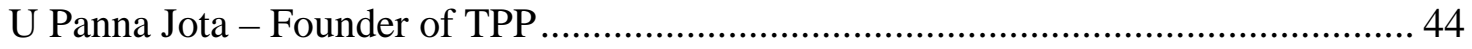

Tea Time with Ashin Wirathu, the Buddhist Terror.................................................. 48

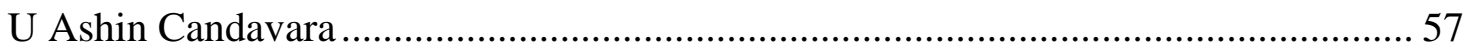

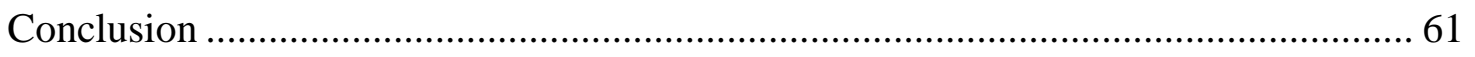

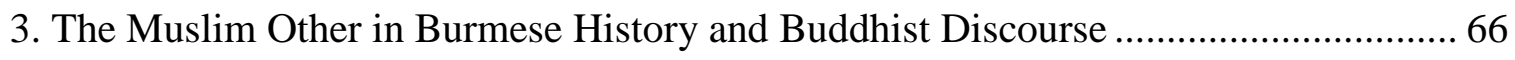

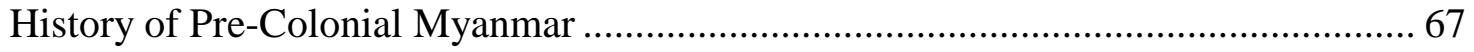

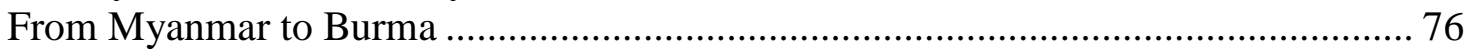

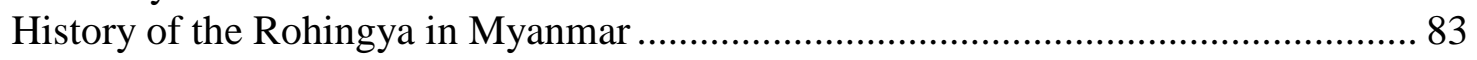

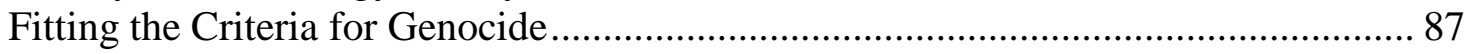

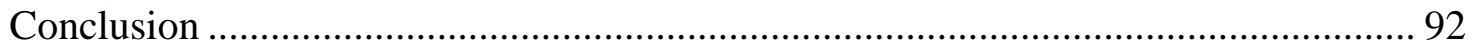

4. Analyzing Myanmar's Xenophobic and Misogynist Discourses and Actions ............. 95

Theorizing Women in Myanmar........................................................................ 102

An Analysis of U Ashin Wirathu's Discourse and Actions...................................... 97

The Myth of the Muslim Rapist....................................................................... 110

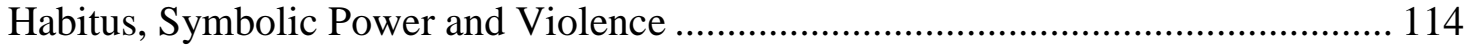

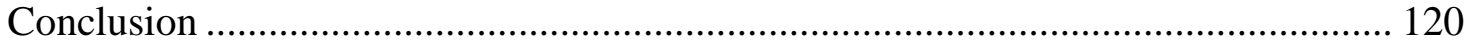

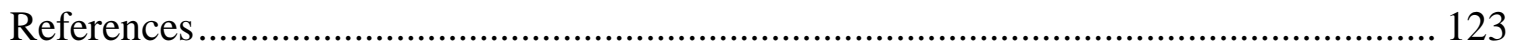




\section{Introduction}

This thesis delves into the seemingly pro-female claims of the Buddhist nationalist 969 Movement, especially those of U Ashin Wirathu, who insist on the dire need to protect Buddhist women from Islam; it contrasts those pro-female claims with the 969's use of rhetorical violence against the Rohingya Muslim minority and the nationalist's treatment of Buddhist nuns (saya-leis). Using field interviews with Buddhist saya-leis, laywomen, nationalist and non-nationalist monks in Myanmar, I analyze the role of gender politics in discourses of religious nationalism among Theravāda Buddhists, positing that gender plays a key role in their religious and ethnic identity formation. I also analyze Buddhist narratives, doctrine and histories read by my subjects that contribute to the Burmese nationalists' persecution of the Rohingya minority in the Rakhine state, a persecution that is largely supported in Burmese society. My subjects use the reading selections I have chosen as nationalist frameworks, a guide for the inherent qualities of women and reasoning for the female gender birth as karmic retribution. Although the 969 claims that they are abiding by the Vinaya, they are selective in the Buddhist discourse in which they interpret to support their actions toward the Rohingya and women.

I set out on a journey with my colleague and research partner, Darbee Hagerty, to explore the lives of Buddhist women in Myanmar. I felt a bit uneasy about how realistic the goals I set for my research actually were. Several mentors and scholars in the field warned me that it would be very difficult to attain the information I was seeking from female monastics and especially to get one-on-one time with Time magazine’s "Buddhist Terror,” U Ashin Wirathu. I sought to answer several questions. Are the politically wellconnected monks of Wirathu's nationalist 969 Movement true followers of the Theravāda 
Buddhist dhamma? Are they equally respected among Buddhist nuns, laymen and women? Do they support equality among women within the monastic community? How do they feel about reviving the bhikkhunnī order? Are the nuns in Myanmar split among nationalist and democratic supporters, as it appears to be within the monk communities (i.e. 969 Movement, Ma Ba Tha and the monks behind the 8888 uprisings)?

Although Mandalay was our home base, we traveled to Sagaing on most days. Sagaing is a monastic community that houses hundreds of nunneries and monasteries. However, less than a quarter of those nunneries provide adequate education to their nuns. This is mostly because while monasteries receive government funding and are protected by the monastic code and stipulations, nunneries depend on private funding and have little to no official status (Kawanami 2013). While in Myanmar we also paid visits to Bagan, Yangon, Innwa and Amarapura. The socio-economic class divide was highly dependent on government, foreign and monastic connections in all the areas we visited. All people who are not connected to any of these sources are very poor and have little accessibility to money or goods. It was apparent in the living conditions and lack of access to amenities and education in the non-foreign- or government-funded monasteries and nunneries.

My subjects come from lower and middle economic classes. The following narrative discusses my experience shadowing the lives of Daw Nang (Buddhist laywoman), Ma Candasiri (a struggling Buddhist nun), U Panna Jota (a non-969 Buddhist monk), U Ashin Wirathu (a monk and leader of the 969 Movement) and U Ashin Candavara (a monk and 969 supporter). This journey brought me into contact with several perspectives among the Buddhist community in Myanmar regarding issues 
pertaining to gender equality, religious nationalism, prejudice, and what it means to them to follow the Theravāda Buddhist teachings in the Vinaya (the monastic code of conduct from the Pali canon).

Herein, I also retrace the history of Buddhist women and nationalism in Myanmar. I also address the contested arrival and legitimacy of the Rohingya in the Rakhine state. Harriden (2012), Taylor (2009) and Myint-U (2006) provide the framework to investigate the pre-modern and colonial-era history of Buddhism's connections with political power and the rise of nationalism in Burma. They also assist in the investigation of the claim that Burmese women historically held a great deal of authority in pre-colonial Burma. Zarni and Cowley (2014) provide the most inclusive account of the history of violence against the Rohingya. Their work describes how the 35-year plight of the Rohingya fits the criteria of genocide, addressing the civilian and governmental abuses inflicted upon the Rohingya and support my argument against nationalist historiography, which supports the law rejecting their citizenship. Finally, Walton and Hayward (2014) provide the most thorough account of the present-day democratization process in Myanmar through recent interviews with the 969 Movement's leader, U Ashin Wirathu. Walton and Hayward also shed light on the narratives that accompany the perpetrators' justifications of violent action, which greatly helped me to connect the narratives used in my interviews to history and sacred text.

Pierre Bourdieu's (1977) theories of habitus, symbolic power and symbolic violence support my argument. Buddhist warfare against the Rohingya (and other Muslim communities) is caused by the anxiety memorialized and embedded among Buddhists through Myanmar’s nationalist Buddhist rhetoric that conveys the idea of losing the 
sangha to Islamization. Simultaneously, nationalists deem Muslim men as rapists to justify the control of women—particularly, Buddhist women—which they state is for their "protection.” I posit that the rhetoric of preserving Buddhist culture has become an integral practice of the religion, based on the discourse about the history of migrations of non-Buddhists brought in because of British colonization of Burma. Nationalists interpret past wars in Burma as acts to "purify" Buddhist ethnicities against colonizers. They see violence as the only way Burmese society has managed to escape this destiny in the past.

I have selected several socio-historical accounts for the Burmese and Rohingya ethnic groups to shed light on the explanations used by the monastic-led, nationalist "969 Movement” to support their actions to ethnically cleanse Burmese society. U Ashin Wirathu, a Theravada monk and the movement's leader, has been internationally criticized for provoking what Jerryson (2011) calls "Buddhist fury" that has led to the death of hundreds and the displacement of thousands of Rohingyas. Wirathu claims high moral ground by saying that he has never commanded any Buddhists to kill, as it is not Buddha-nature to kill a sentient being. While no outsider can claim knowledge of another's true intentions, when one's critical words have stoked the anger of others to violence, and one then repeats those words, I assert that one can expect to be morally implicated in subsequent violence.

Buddhist ethicists such as Harvey $(2000,95)$ assert that, in Buddhism, life has an ultimate value that should never be sacrificed in the name of another value such as compassion, or, in this case, to prevent Islamization or to nationalize Buddhism in Myanmar. The results of Wirathu's speeches and demands to purify the Rakhine state have already caused riots, murders and the destruction of homes, mosques and Muslim 
schools. Therefore, to cling to a narrative that produces hatred toward the Rohingya, I argue, is intentionally violent and a violation of the most fundamental tenets of Buddhist ethics. Despite his insistence that the 969's actions conform to the Buddhist canonical texts and practices, Wirathu's invectives against the Rohingya seem to communicate that protecting Buddhism and its followers in Myanmar is far more important than any other Buddhist ideology.

Buddhist nationalists treat women with deep ambivalence. The 969 Movement and Ma Ba Tha ${ }^{1}$ claim they care about women's rights, but what they actually do is to cater to the families of Buddhist women by supporting a law that grants a legal avenue to oppose any interreligious marriage. The 969 also claim that the Rohingya are inherently violent, raping and forcibly marrying and converting Buddhist women, but have no viable support for these claims; instead, Wirathu makes only irrational comparisons of them with ISIS. However, history shows that Myanmar's struggle for implementation of a fully Buddhist state is not solely Wirathu's invention. Nationalism, kingship and colonization are major historical influences on the present situation.

\section{Chapter Outline}

In Chapter 1, I introduce Daw Nang and Ma Candasiri. Daw Nang is a devout Buddhist laywoman and owner of an English-medium school. Her views provide a take on the irrelevance of feminism for many Buddhist women, a view perpetuated by men and the history of women in Myanmar. For this reason I begin the chapter with a brief historical

\footnotetext{
${ }^{1} \mathrm{Ma} \mathrm{Ba}$ Tha is the “Association for the Protection of Race and Religion,” led by nationalist monks who dominate the political space for issues pertaining to Buddhism in Myanmar.
} 
background of women in Theravāda Buddhism. Ma Candasiri is a Buddhist nun who struggles to make ends meet due to the lack of support from the lay community as well as the absence of any foreign and government support. Many nuns in Myanmar are in the same situation as Candasiri. Daw Nang led me to the prestigious Sakyadhita Nunnery funded by foreign donors in order to see the grandiose difference among connected nuns and average nuns like Candasiri.

In Chapter 2, I introduce the lives of three monks who have little to no trouble getting by as monastics in Myanmar. I show that the more connected the monks are to carrying out government agendas, the better off they are financially. The monks from New Ma Soe Yein monastery, U Panna Jota and U Ashin Wirathu, were not economically impoverished. However, U Ashin Wirathu has a voice in government policies, such as the passing of the law hampering interreligious marriage, which grants families control over whom women may marry. Panna Jota’s political views are more liberal, democratic, and feminist, but less talked about in a social context. In this chapter, I provide an account of my interview with Wirathu with respect to his views of the Muslim communities of Myanmar, particularly the Rohingya. I also addressed the lack of ordination among women in Myanmar with him. I asked Wirathu for his thoughts on whether women should be ordained in order to give them an opportunity of enlightenment, spiritual growth and "protection."

Chapter 3 addresses the historical context of the Muslim “other” in Burma. I focus on the historical accounts of the Buddhist monarchies, nationalist / colonial accounts and the history of the Rohingya in Myanmar. Additionally, I use Zarni and Cowley’s (2014) criteria for genocide to provide a framework for understanding the plight of the Rohingya 
minority as a form of genocide. I begin to interrogate why Wirathu, like other nationalists in Myanmar, distribute misogynist and anti-Muslim rhetoric, arguing that it is a response to globalization in light of Myanmar's relative isolation since the mid twentieth century.

In Chapter 4, I use transnational feminist theory of Mahmood (2005) to

understand how to encounter women who appear not to resist their portrayal at the hands of Buddhist nationalists. I juxtapose this theoretical position with Angela Davis’s (1981) critique of the myth of the Black rapist to shed light on the pervasiveness of the Buddhist nationalists' perceptions of the Rohingya in Burmese society. I conclude by examining the logic of Wirathu and other Buddhist nationalists’ actions through Bourdieu’s (1977) concepts of habitus and doxa, which allows me to acknowledge my own privilege in being able to analyze their discourse and actions from an American, secular, feminist perspective with the help of Saba Mahmood (2005).

\section{A Note on the Use of the Names "Burma" and "Myanmar"}

I have had mixed feelings regarding what name to designate to Myanmar/Burma in this thesis because of the politics associated with the country's name change. The British named the region Burma during their colonization after the First Anglo-Burmese War (1824-1826). The country became an independent nation in 1948 and continued to be known as Burma. For 60 years, ruling parties crushed pro-democratic action; in 1989, it was officially renamed the Union of Myanmar. According to Copley, the name Myanmar carries a nationalist connotation, as it only refers to the Burmese Buddhists and excludes 32\% of the country's population (cited in Gier 2013, 67). 
One of my Burmese contacts, Thu Reign Aung, a Contract Analyst for the United Nations Office for Project Services in Yangon, uses the name Myanmar, following the United Nations (UN) practice to use the official name of countries in accordance to what its own government calls it. Thus, the use of Myanmar has both a nationalist connotation and is accepted by the UN. Conversely, the name "Burma" simultaneously supports the legacy of British colonization and the National League for Democracy (NLD). The NLD’s leader, Aung San Suu Kyi, has stated that she prefers the name Burma instead of Myanmar. Since the military junta, who imprisoned her, took power of Burma without an election and implemented the official name change, she refuses to abide by it. She resents the 1988 takeover by the junta and its sudden change of the country's name without a vote of the people (Schiavenza 2014). Scholars such as Kawanami (2013) and Walton and Hayward (2014) use the name Myanmar. Therefore, out of respect for all the people of Myanmar/Burma I will use both throughout my work depending on the period and subject.

This work is an account of my own perceptions and how they fit into my own habitus. Although I do not agree with certain perspectives provided by my subjects, it does not undermine the respect and gratitude I hold for them for allowing me to conduct this fieldwork. To be an ethnographer is truly an honor and I appreciate every single piece of information they shared, whether it goes against my own beliefs and morals or not. My responsibility was to document and analyze, using the works of scholars and philosophers. As a humanitarian, it is my own personal duty to understand that we are all products of the environments into which we were born and the education accessible to us. 
While I will always side with women and minorities being that I am both, I understand that all humans encounter some kind of adversity that fuels feelings that manifest differently across the globe.

\section{CHAPTER 1}

Myanmar's Saya-leis:

Betwixt and Between "This Worldly" and "Other Worldly” Domains

This chapter traces the history of the bhikkhunī lineage in Theravāda Buddhism through what is documented in the Buddhist canon. I sort out specific Buddhist texts relating to the way that Burmese Buddhist attitudes toward women are shaped. Next, I address the status of Buddhist nuns in Myanmar. I provide a few examples of how their lives as nuns differ from those of monks in addition to their inability to attain full ordination.

In this chapter, I introduce my “Burmese mother,” Daw Nang, and my “soul sister," Candasiri. These subjects differ very much in terms of worldviews, class, status and education. Daw Nang is a middle-class teacher at an English-medium school who is in her sixties; her family has Chinese ancestry. Candasiri is a Buddhist nun in her forties enrolled in the MA program at Sitagu Buddhist Academy. Candasiri comes from a poor family in the Shan state. Although these women differ very much in almost every aspect of their lives, one thing was constant: the desire to come back in the next life as a man. They were both also relatively silent on issues pertaining to Wirathu. While Daw Nang shares his views of Muslims to an extent, she was not interested much in the subject.

I detail the curse of womanhood in Myanmar in this chapter as karmic retribution and canonical construct. I reflect on kamma and how it affects the livelihood of Buddhist 
nuns and laywomen in Myanmar. The government's support of the sangha and restrictions imposed on the lives of women based on Buddhist ideals tends to shape the outcome of a woman's life greatly in Myanmar. This is especially significant for poor women who cannot afford access to secular education. These karmic ideals also shape the way that race is viewed and through my subjects we see how gender and race determine status and even accessibility in Myanmar.

\section{A Brief Historical Background of Women in Theravāda Buddhism}

According to the Pāli Canon, in Buddhism both women and men can attain enlightenment. Nonetheless, this is a matter that has been argued for 2,500 years. At times, it seems as if Buddhist texts contradict the Buddha's intent to veer from the Brahmanical hegemony present in society during his lifetime. Sponberg (1992) makes a noteworthy reference to Buddhist attitudes shaped by the rapid development of the eastern Gangetic Valley and newfound agency provided to those who were formerly marginalized in the prevailing Brahmanic culture. Both of these factors were heavily influenced and aided by the new technology of iron smelting as it provided more growth for those involved in agriculture and those involved in development of weaponry. The new technology fostered better tools for both agriculture and warfare strengthening the urban society. This boom created urbanization along the eastern Ganges during the Age of the Wanderers, which in turn created merchant and artisan classes that undermined the social classes in place by the varna system. This opened new roles for women, at least for a brief period, opportunities never before seen in South Asia. This provided women and 
those of the lower classes the autonomy to explore their religious vocations (Sponberg 1992).

Records of the Buddha's resistance to allow a bhikkhunī order, insisting that Buddhism would last for no more than 500 years by accepting women into the sangha, suggest misogynist revisionism. One must keep in mind that the recordings of the Buddha's words were written by men hundreds of years after the Buddha’s death (Puntarigvivat 2001). However, there are also many sources and suttas that support the roles and achievements of women in Buddhism. In the Samyutta Nikaya (the third collection of the Sutta Pitaka within the Tipitaka), King Kosala was distressed about the birth of his daughter Mallika. The Buddha responded:

Do not be perturbed O, King, A female child may prove Even a better offspring than a male, For she may grow up wise and virtuous (Puntarigvivat 2001, 214).

This passage is indicative of the common reaction during the Buddha's time to the birth of a female instead of a male. Although the Buddha exhibits equality and respect for women throughout this passage, he had to be persuaded by Ananda, his faithful disciple, on several occasions to create the bhikkhuni sangha and put aside patriarchal hegemony. Mahapajapati Gotami was the first bhikkhunī as well as Buddha's stepmother and aunt. Her ordination is described in the Pāli story found in the Cullavagga within the Theravāda Vinaya. In the story, Mahapajapati three times requests a nun order for women. The Buddha denies her this request three times without explanation (Horner 1952). 
Despite his refusal she shaved her head, dressed in monastic robes and followed the Buddha with a group of Sakyan women to Vesali. After witnessing her exhaustion and swollen feet, Ananda took pity on her. Once he heard the account of her unsuccessful request for ordination despite her devotion to Buddhism, he approached the Buddha, but was unsuccessful as well until he took a different approach. He asked the Buddha, if women renounce the material world and seek refuge in the dharma and discipline are they not worthy of arahantship? Was the woman who served, as "foster mother, nurse, giver of milk, who suckled him as a child,” not deserving of arahantship? Only after this persuasive dialogue did the Buddha reply that indeed they were (Sponberg 1992, 6-9). The Buddha was finally convinced, although not without establishing the Garudhamma (The Eight Heavy Rules) (Puntarigvivat 2001).

The Garudhamma maintained a social hierarchy over women in the monastic order, reflecting the gender inequality already prevalent in the lay community. The Eight Heavy Rules are as follows:

1. Any bhikkhunī, no matter how long she has been in the order (original text translates to even if ordained for 100 years), must treat all monks, even if he is rude or been novice for a day, as if he were her senior.

2. During the annual rainy season retreat bhikkhuniss should not take up residence where a monk is unable to supervise.

3. Monks are responsible for setting the dates of biweekly assemblies.

4. Aside from the community criticism provided after the rainy season retreat, nuns must also invite criticism from the monks.

5. Monks share in setting and supervising penances for the nuns.

6. Monks share in the ordination of nuns.

7. Nuns shall not revile or abuse monks.

8. Nuns shall not reprimand monks directly (Falk 2001, 201).

To create these boundaries for women was the only way to market Buddhism to a patriarchal society. Buddhism did not undermine patriarchy, but it did allow women to 
enter monasticism. It legitimized the role men were conditioned to adhere to in this society, which they perceived as natural. If the Garudhamma actually dates back to the Buddha, he may have assumed that any true Buddhist, once enlightened, would seek the annihilation of gender rules, leaving those who clung to patriarchal ranks to karmic retribution. As human beings, we tend to change language in order to convey the essence of meaning in a relatable sense. Who is to say if these were the Buddha's words, this was not the case?

The strongest argument I have found in reference to these rules that deem women as subordinate to men is that Buddhism was an oral tradition until the Pāli canon was written down (by men), 400 years after the Buddha's death. They may not reflect the Buddha's words verbatim, but rather the patriarchal society’s interpretation instead (Satha-Anand 2001, 113). Puntarigvivat $(2001,217)$ agrees with this and claims that some scriptures were added with male bias, particularly the eight rules and the prediction of the life of Buddhism. Nevertheless, for the first time in the history of religion, women were able to partake in monastic life with an established order of nuns (ibid., 213). Therefore, the admittance of women to the order was revolutionary in itself. Additionally, a contradiction I found during my research was the inaccuracies reported by those who have translated the Pāli and Sanskrit versions of the text. According to Sponberg (1992), there is nothing in the Sanskrit version that suggests Ananda took a different approach when convincing the Buddha to create the Bhikkhunī Sangha. The Pāli version depicts the change of approach by utilizing Mahapajapati's roles as a mother to change the Buddha's mind. In the Sanskrit version, Ananda simply repeated his request for a female order verbatim instead of providing a rationale utilizing 
her role as a mother. Furthermore, the Sanskrit reading clarifies that the Buddha implements the Garudhamma as a preventive measure against the obstructions the bhikkhunīs will have to overcome to live their lives as nuns (Sponberg 1992).

When the Buddha first established the sangha, there were no concrete rules to designate the monastic order. As incidents began to occur within the growing monastic community, he compiled the Pātimokkha. The Pätimokkha distinguishes the expectations of the monastic order from that of the lay community. As the rules increased to 227 for the bhikkhus and 311 for the bhikkhuniss the Venerable Upali gathered the rules to create the Khandakas, which organized the rules according to topic. Presently, the Pātimokkha is within the Sutta Vibhanga, organized in a fashion that presents the origin story along with the rule. This was needed, as some rules tend to be specifically about disciplining dishonorable behavior (Bhikkhu Thanissaro 1994).

The spread of Buddhism continued throughout the first period, dating from the oral traditions when the Buddha was alive (late $5^{\text {th }}$ to $4^{\text {th }}$ century B.C.E.) to the time of Ashoka’s empire (272-236 B.C.E.), which spread Buddhism throughout the Indian subcontinent. Many women at this time achieved nirvana as is recorded in the Therighātā. The second period for Buddhism is from the time of Ashoka until 250 C.E. during the rule of Satavahanas in the south and Kushanas in the northwest. During this period, not much was written, except for the testimonies left inscribed on monuments by donors. Bhikkhunīs at this time were still very much present and evidence exists that they were as abundant as monks. These records also show that they provided gifts as well as received donations, indicating that the community supported the nuns. 
The third period of Buddhism came in after the third century C.E. At this point, recordings show the bhikkhuniss were less abundant and the last recorded gift received from a nun was in 550 C.E. in Mathura (Falk 2001). Falk mentions the importance of Yijing's brief observation in $7^{\text {th }}$ century C.E. about the deprived state of the nun order. They were strictly supervised; they had to walk in two's outside the monastery grounds and in fours when visiting lay households. He claimed that the monasteries had no special supply of food for them. Additionally, he states that the nuns lived much more modest lives than the lavish monks (Falk 2001, 198). Apparently, the nuns ran into trouble finding economic support. Byrne points out that the Garudhamma rules negatively affected the dana (the financial support) nuns received from the lay community because it placed the monks as a higher authority for the lay people to receive blessings. This is also a cause of the orders dying out in most Buddhist countries with the exception of China, Japan, Korea and Vietnam—which were predominately Mahāyāna (Byrne 2012).

Despite their subordination to monks, the bhikkhunī sangha gained popularity among women in India and spread along with Buddhism until the $10^{\text {th }}$ or $11^{\text {th }}$ century (although other sources claim end of $12^{\text {th }}$ ) when Islam began to dominate India (Puntarigvivat 2001, 217). Eventually, the bhikkhu and bhikkhunī lineages began to die out. In 1597, the bhikkhus in Arakan (now a state in Myanmar) revived the bhikkhu lineage in Sri Lanka (Perera 1988, 73). The bhikkhunīs were not so fortunate. Their lineage only survived in China, Korea, Japan and Vietnam from the original Sri Lankan Dharmagupta sect (Puntarigvivat 2001, 217). These sects became Mahayana. Recent excavations revealed stone inscriptions that suggest a bhikkhunī order might have reached Myanmar. However, there is not enough evidence to ascertain where they came from, 
whether or not they were established in Myanmar and where they went (De Silva 2004, 134-135).

During U Nu’s tenure as Prime Minister of Burma (1948-1962), ${ }^{2}$ Myanmar was open to foreign students who wanted to study the dhamma at a university level. Such study was popular among Nepalese nuns who were not officially ordained bhikkhunīs. This was short lived, as the economy collapsed and the laypeople could not provide for the nuns any longer due to the political regime. It took foreign donors and family backing for foreign nuns to survive the conditions presented at the time in Burma and although some were successful, others were forced to go back home and the diversity among monastic students began to drop. Nuns began to get sick from malnutrition and were forced to leave the country to avoid death by starvation or illness. Between 1966 and 1980, Burma closed its doors to foreigners. It was not until 1980 that it reopened its doors to allow foreigners to study the dharma once again (LeVine 2004, 146).

\section{Thilashins - Saya-leis}

Buddhist nuns in Myanmar are referred to as Thilashins. ${ }^{3}$ However, during my fieldwork I was told that to call them saya-lei (which translates as "little teacher") is considered more respectful and as I witnessed, far more common than the word thilashin. Monks are referred to as saya-daw (honorable teacher). The first Buddhist assembly

\footnotetext{
${ }^{2} \mathrm{U}$ Nu was a leading Burmese nationalist monk and first Prime Minister of Burma. He made Buddhism the official religion of Burma in 1961. This act was demolished when Ne Win took over in 1962 and led the Burma Socialist Programme party for the next 26 years (LeVine 2004, 146).

${ }^{3}$ Thilashin is a combination of two words, thila and shin. Thila is the Burmese vernacular equivalent for the Pāli term sila, meaning self-restraint and discipline as well as virtuous conduct and purity. The term shin is the context means the "one who upholds" or "one who is equipped with (Kawanami 2013, 29).
} 
created by the Buddha consisted of four categories: bhikkhu (monk), bhikkhunī (nun), upasaka (pious layman) and upasika (pious laywoman). Saya-leis are in the order of upasika: pious laywomen. This leaves them in a position among those who are directly affected by the sangha, but not equal to the level of the monks (Kawanami 2013, 114115).

Saya-leis play supportive roles to the sangha and are not ruled by it directly; instead they respond to the monks. They are betwixt and between the sangha (Kawanami 2013, 127). As Kawanami explains, nuns are between the spiritual world of the monks and the secular domain of the laity. This ambiguity has been reflected in the treatment of their bodies after death, in daily meals and in layperson offerings. Nun's bodies did not receive the same respect as monks before technology allowed crematoriums to make cremation more accessible. Before, nuns’ bodies were buried during the rainy season because it was difficult to cremate them in the heavy rainfall. Monks, however, were still cremated (Kawanami 2013, 128).

Activities and interests of the monks are discussed at a national level of the sangha and three regional tiers. The Supreme Sangha Council, The State Central Working Committee of Sangha and The Patron Committee of Myanmar Sangha are the national organizations for the monks. Saya-lei issues fail to extend to that level. Saya-leis issues only extend to the Divisional Council of Monks, which responds to the aforementioned national councils (See Figure 1) (Kawanami 2013, 114-15). The saya-leis are thus marginalized in society and in terms of being heard by the Buddhist Sangha on a national level. Additionally, if any concerns related to gender or the feminine are brought to these councils, they are addressed and decided upon by monks alone; nuns or even 
laywomen are not included. Originally, there was no council to hear nuns' issues. It was not until 1982 that this was created. It was intended to create a national legal administrative framework representing nuns. However, this never happened as promised, and the plan for adequate representation for female renunciants was phased out in the early 1990’s. Therefore, although nuns' funding, duties and responsibilities are theoretically independent, they still have to act in compliance with the rules of the monks (Kawanami 2013, 129). This marginalization and lack of power is illustrated in the table below.

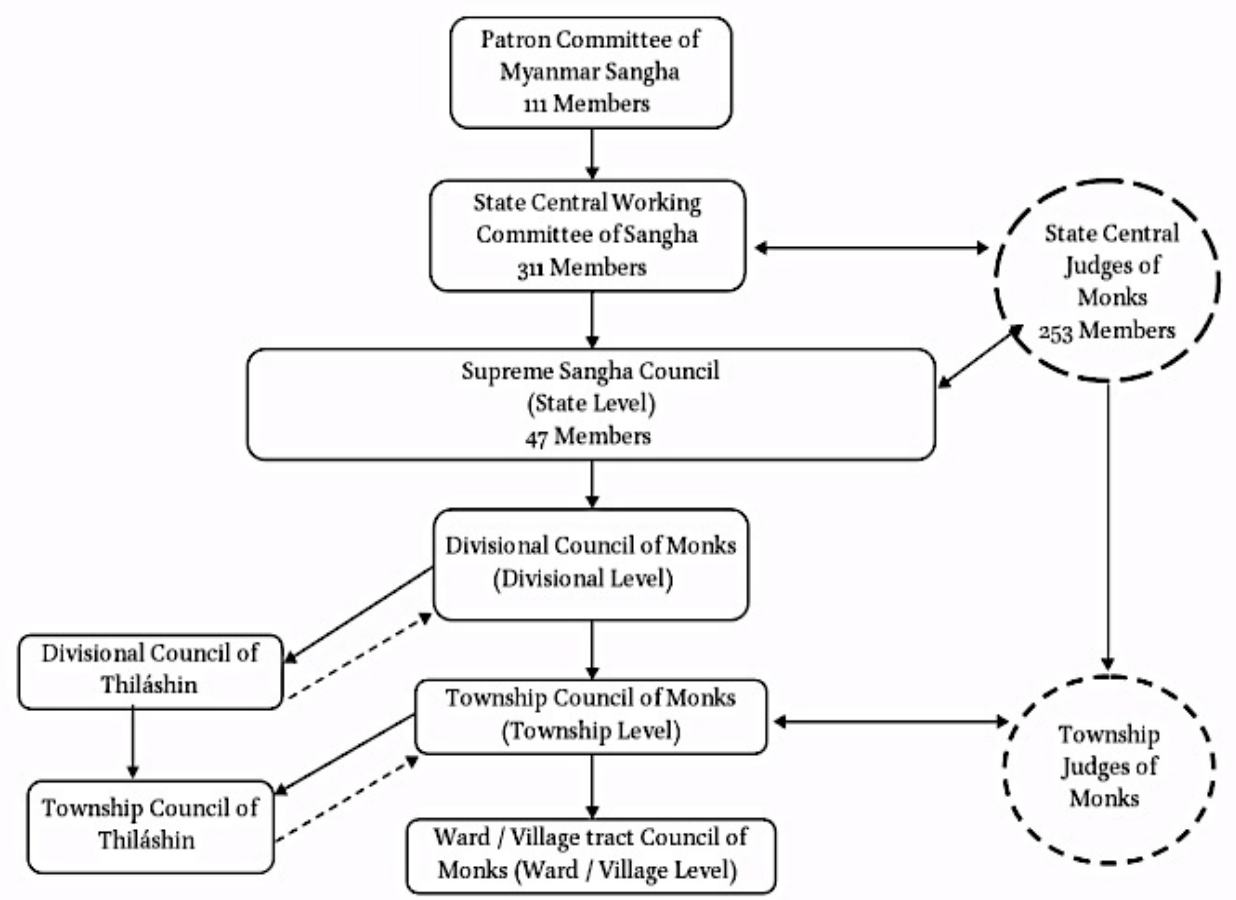

Figure 1. Kawanami's (2013) national monastic organization of Myanmar chart.

The nuns do not receive the same education, layperson support, comfortable living conditions or respect as monks (Kawanami 2013, 159). Often, Burmese laypeople 
have reinforced the narrative that women belong in the kitchen through the donations they provide (if any) for the saya-leis. Raw rice is given to the nuns instead of prepared food when they collect alms. This action constructs an identity role for these women-to cook for the monks, who are not allowed to cook. I witnessed this myself during my stay at Thila Nyunt Nunnery. Several nuns spend most hours of their days in the kitchen. Although most of it was in order to feed the nunnery, several days a week, they had monk visitors walking through the town. This delivers the message that women should cater to men and take care of the meals and chores despite their renunciation choices. In some places in the Shan state in Myanmar, nuns are not even allowed to walk through the town as they are said to bring bad luck (Khuankaew 2007, 177). However, they still abide by the precepts and monastic laws they are given despite the male dominated sangha.

The majority of Saya-leis only take nine precepts:

1. Abstain from taking life

2. Abstain from stealing

3. Abstain from sex

4. Abstain from lying

5. Abstain from taking intoxicants

6. Abstain from taking solid food after midday

7. Abstain from dance, singing, flower garlands, perfume, cosmetics or adornments

8. Abstain from sleeping on high or luxurious beds

9. $\quad$ Send loving-kindness to all sentient beings

Some adhere to Ten Precepts if they are funded and taken care of accordingly:

10. Abstain from handling gold and silver (money)

Most Saya-leis take nine precepts since their survival in the community is not feasible without serving the fully ordained monks who have taken the Ten Precepts (Kawanami 2013, 35). Still, from my own fieldwork I witnessed many monastics handling money. 
One of my main subjects, U Panna Jota (a monk and teacher at New Ma Soe Yein) said, "In modern Myanmar society we must handle money and make sure the monastery runs accordingly. We are responsible for all the novices. If we do not handle money, we would have to depend on the Mandalay community to cater to the needs of 2500 monks daily. That is not possible. Some days we do not have donors.” However, the monks at New Ma Soe Yein always had cooks and lay people present to serve them warm meals while I was there.

For saya-leis it is much more difficult. I witnessed the nuns at Thila Nyunt struggle to buy enough rice and chicken to feed the nuns at the nunnery. Despite their struggle, they managed to feed and house several traveling monks while we were there. The monks sat at the headmaster's table and she bowed down to the noticeably younger monks although she has been a nun for over 50 years. This obligation for self-support prevents them from renouncing the material world, reminding them of their lack of full ordination, and therefore preventing them from attaining the highest goals in Buddhism, namely nibbāna. Ideally, wealthy family members support the saya-leis who take the Ten Precepts. This is uncommon in poverty-stricken Myanmar. Preventing the saya-leis from taking the Ten Precepts is parallel to the patriarchal narratives expecting women to play a role solely to satisfy male desire and aide their progress, in this case toward enlightenment and escape from samsāra.

Inaccessibility to the histories of the bhikkhunī sangha, along with the reminders that it is no longer in existence, creates in the saya-leis inferiority to male monks who do have access to many monk tales in the commonly distributed editions of the Dhammapada in Myanmar. Lack of access to bhikkhunī histories also supports the 
narratives that claim that to reincarnate as a woman is karmic retribution for a previous life as an evildoer (Khuankaew 2007, 176). While Buddhists can differentiate biological sex from gender, they overlook that sexual identity is at least as socially constructed as it is biologically given. Perhaps this lack of acknowledgment is what allows this discrimination toward women in terms of soteriological inclusiveness (Sponberg 1992).

In many cases, for underprivileged women whose families are unable to support them as nuns, such teachings, combined with their reality of poverty, confer feelings of unworthiness and despair that can lead to prostitution and trafficking. These women feel as if their merit is to suffer because it is what Theravāda Buddhism has taught them since birth. In turn, women see their suffering as meritorious because suffering their subordinate status in the current life wipes the kamma slate clean for the next life where the possibility of reincarnating as a man is plausible. It is embedded in their society as well, making males more prone to assuming the right to control the lives of women. In Myanmar, even respected women internalize this idea embedded in their psyche through religion and culture.

\section{Daw Nang and the Nuns of Thila Nyunt and Sakyadhita Nunneries}

Upon our arrival at the Mandalay airport in Myanmar, the woman we came to know as our Burmese mother, Daw Nang, greeted us with a warm smile. She is a classy woman who dresses in traditional Myanmar dress. She wore embroidered handmade dresses and skirts every day and we could smell the jasmine in her hair 10 feet away. She picked us up in one of her daughter's vehicles. She did not hesitate to explain to us that she does

not drive and has never had a desire to because of the lack of organization in the streets of 
Myanmar. Her daughter's car was an air conditioned SUV no more than a few years old. During my stay, I became aware of what a luxury it is to have one of these in Myanmar. The majority of the population gets around on motorbikes, bikes and public transportation. Daw Nang's home was filled with western amenities. She had a washer, dryer, cable, flat screen televisions, internet and air conditioning. She also had several maids and was searching for a new chauffeur during my stay in Myanmar. I was astonished at how westernized the premises were and I asked Daw Nang what social class she considers herself to fall under. She refers to herself as a middle class citizen in Myanmar. I assumed she was part of the upper class because the differences in her living circumstances and those of the lower class were so great. I soon came to realize the gaps among the classes in Myanmar are worthy of a dissertation on their own.

Daw Nang is a widowed primary school owner and English teacher. She has five daughters. Two of them have left Myanmar. One resides in Singapore and the other in Kentucky. Both are married. Daw Nang owns a five-story building where her school is located. The building houses her English / Burmese medium primary school that provides secular education to children in grades pre-school thru sixth grade. This same building serves as her home, which she shares with two of her daughters. One daughter never married and observes five of the Buddhist precepts. As I discuss later in the chapter, this is a common practice for single women in Myanmar, at least publicly. Another is divorced with two children. The fifth daughter is married and lives with her husband and children.

Immediately, Daw Nang situated us in a hotel owned by one of her former students. The Hotel Victory Point became our home base for the next 35 days. We had air 
conditioning and spotty but dependable internet service. Daw Nang constantly catered to our needs, had our laundry done, took care of us when we were ill from our questionable eating habits and consistently spoiled us rotten with treats and dinners. She even was kind enough to lend us a phone during our stay so that we could communicate with our subjects. Daw Nang was the perfect hostess and guide to Myanmar. I felt comfortable asking her everything that occurred to me despite the topic’s controversial standing.

Soon we began to discuss equality among genders in Myanmar. When I asked Daw Nang if she felt that the Theravāda Buddhist narratives expressing that women shall be subordinate to men and that female incarnations are lower incarnations than men affect the way society treats women outside of religion, she responded, "We do not have any intention to be on the same level as men. This is only in place on a religious level such as when placing gold leaf on statues of the Buddha or climbing pagodas.” This was clearly my point: at a religious level women are not worthy of placing gold leaf on a statue of the Buddha regardless of whether they follow the precepts. Women also cannot pray within a certain proximity of some statues. All nuns are subordinate to monks despite their time as a monastic. However, Daw Nang's answers always seem to contradict my questions because feminism is a radical western thought in her mind. She claims that feminism creates problems and insecurities that Burmese women just do not care about. In order to avoid veering from my ethnography, I address this eastern vs. western feminist thought through my analysis in Chapter 4, utilizing the theoretical frameworks of Mahmood and Angela Davis.

During one of my praises to her about her hospitality she jokingly said, "I am a good person in this life so that perhaps I can come back as a man in the next life.” When 
we discussed my son, she said I was very lucky to have a son. She said she still had a way to go on merit since she gave birth to five women. I was stunned that although her daughter was in the car with us, no one found that statement as egregious as I did. The second Noble Truth is the Noble Truth of the Origin of Suffering: $\tanh \bar{a}$ (desire). Tanh $\bar{a}$ leads to kamma (action), which have vipāka (consequences) that are dependent on whether the kamma was puñña (positive) or pāpa (negative) on a moral scale (Keyes 1983, 261). In this instance, I could not help but wonder if this vocalization of her misfortune for not birthing a male when she was blessed with five females, one of which was present to hear this statement could possibly work against Daw Nang and her concern for good kamma accrual that could lead to her rebirth as a male. Does this desire fall under acting on ignorance, which results in negative kamma? Keyes $(1983,262)$ answers this question like so,

If one acts in ignorance - giving vent to one's passion of greed (lobha), lust ( $r \bar{a} g a)$, and anger (dosa) - one will commit immoral acts and will suffer negative consequences. If, on the other hand one acts with awareness, suppressing the impurities (kilesa) of one's nature and following the desire to reduce or eliminate suffering, one will perform moral acts and experience positive consequences.

I believe intent is very important here. Daw Nang's statement seems ungrateful to western non- Buddhist feminist ears and therefore, under those circumstances this action can be taken as an act of ignorance based on lust for manhood. One can say her good actions are directed toward a karmic gain in another life and therefore lack the authenticity of being good. However, as a western feminist who was able to spend much time with this loving and funny woman I can say that her statements are made in good faith and as a response to my birthing a male. Daw Nang voiced this in order to make me 
feel good about the birth of a male. She did not mean it as a personal attack toward her daughters and, as Buddhists, they both knew that the statement she made was strictly based on the literature and practices they have been indoctrinated with. For this reason only, I deemed the statement as problematic. While I live in a western feminist sphere analyzing eastern Buddhists, I have learned to consider intent while constructing an analysis.

When Daw Nang (2015) and I discussed infidelity among men and women she wished me luck finding a man who will remain faithful and nonchalantly said, "The old buffalo likes tender grass, dear.” She followed that with several statements that cater to men's “innate" desire to be with multiple women and how it is frowned upon for women to do it because we must value our bodies. Daw Nang continued to contribute to the narratives that encourage and support a patriarchal society. Yet, she is a devout Buddhist, a kind and generous woman who bends over backward for her students, the nuns of Sakyadhita Nunnery, her daughters and for me, a complete stranger who was lucky enough to be introduced to her via email. She treated me like family and was always so raw, honest and elegant despite our differing views of Myanmar's social milieu of women as second-class citizens.

I asked for her thoughts toward the controversial legislation, still impending at the time, which would prevent Buddhist women from marrying non-Buddhists if a member of the family objects. The law requires intended marriages between Buddhist women and men of other faiths to be registered with the authorities, which will then publicize the intent to marry. If there are objections, the couple could face prison time (Win Naung Toe 2015). Daw Nang (2015) responded, “This law is beneficial to Buddhist women and 
protects them. The law allows Buddhist women to marry Muslim men, but still have the rights to their Buddhist estates.” Her response was not surprising as one of the law's drafters, MP Saw Hla Tun stated, “This law was written for Myanmar Buddhist women who marry men from other religions so they have equal rights in marriage, divorce, inheritance and taking care of children, as well as have effective protection” (Win Naung Toe 2015). Often in Mandalay I heard locals, monks and nuns repeat narratives almost identical to "official statements" and when asked to elaborate or provide a deeper understanding from their own perspective the question was often dismissed.

Daw Nang consistently brought up Muslims every time I asked about gender inequality within Buddhism and Myanmar. On several occasions, she said that I was studying inequality in the wrong place and that perhaps Islam and the barbaric practitioners of Sharia Law would provide more insight on gender inequality within religion. It reminded me of an excerpt from Burma Past and Present by Lieutenant General Albert Fytche $(1878,66)$, who was the Chief Commissioner of British Burma and Agent to the Viceroy and Governor General of India,

Unlike the distrustful and suspicious Hindus and Mohammedans, woman holds among them [Burmese] a position of perfect freedom and independence. She is, with them, not the mere slave of passion, but has equal rights and is the recognized and duly honored helpmate of man, and in fact bears a more prominent share in the transactions of the more ordinary affairs of life than in the case perhaps with any other people, either eastern or western.

As in this old colonial frame of mind, for Daw Nang, a woman who stood by her man and "helped" him was a "free" woman. Her response, urging me to focus on Muslim, not Buddhist, gender inequality, prepared me to ask her perspectives on U Ashin Wirathu's 969 agenda. 
One afternoon while I was sitting with Daw Zanaka Malini (the head master of Sakyadhita Nunnery) and Daw Nang, I asked about their views on Wirathu's credibility as a Buddhist despite the fact that he spreads hate speech about Muslims. At first they did not know whom I was speaking about, that is, until I referred to him as, "the monk leader of the 969 Movement.” The head nun seemed avoidant and distant. She did not want to discuss politics and that was clear when she stated that political issues do not affect the nunnery because they are cut off from the outside world as nuns and receive most of their donations from foreign Buddhists. However, when specifically discussing Wirathu, she said, "he is a monk granted his position by the sangha and the people. He seems to be misunderstood by the media. If he did not behave like a monk he would not be allowed to be one by the sangha. Therefore, we respect him and the sangha” (Daw Zanaka Malini, 2015). Daw Nang and Daw Zanaka then quickly shut down any further discussion of Wirathu or 969.

None of this came as a surprise to me. Dr. Kawanami explained prior to my fieldwork that I would not get much talk about politics from the nuns at Sakyadhita. Sakyadhita is the most revered nunnery in the Mandalay-Sagaing areas. They have a topnotch education system and excellent sources of funding. It was clear once I visited that these nuns are not concerned with anything but the Buddha's teachings. It was started by Kawanami herself and has been a top nunnery for 16 years. The buildings and nuns were all in pristine condition. All the nuns of adult age held university degrees. There were very few young nuns.

This was not the case for the nuns of Thameikdaw Gyaung and Thila Nyunt. The latter, is where the majority of my research was performed. These nunneries seem like 
villages made up of wooden shacks. Few nuns achieve college degrees because of all the work that needs to be done in order to feed and provide for the residents. They also both house many more underage nuns than Sakyadhita. Most of the child nuns in Thila Nyunt are refugees from ethnic minority townships. At Sakyadhita several nuns had a basic understanding of the English language. At Thameikdaw there was one from India, but who was not present the day we visited. At Thila Nyunt there were two: Ma Candasiri and Ma Candayee. Candasiri, one of my main subjects, explained that there are times when they only collect 50 kyats among five nuns during a day's alms collecting. This was something that struck me as unusual because at one point of my research when I was unable to get to a working ATM, a monk lent me 100 thousand kyats. Candasiri (2015) says, "Sakyadhita is very lucky and rare. Most nuns do not live like they do.” When I asked Candasiri about Wirathu she praised him and said I would be very lucky to meet him because he is very famous. Still, her face lit up when I responded, "I do not know if it would make me lucky, his presence perpetuates violence and I myself prefer peace among all people no matter what religion they choose.” She smiled and whispered, "Oh. You know? Me too, sister, me too.” 


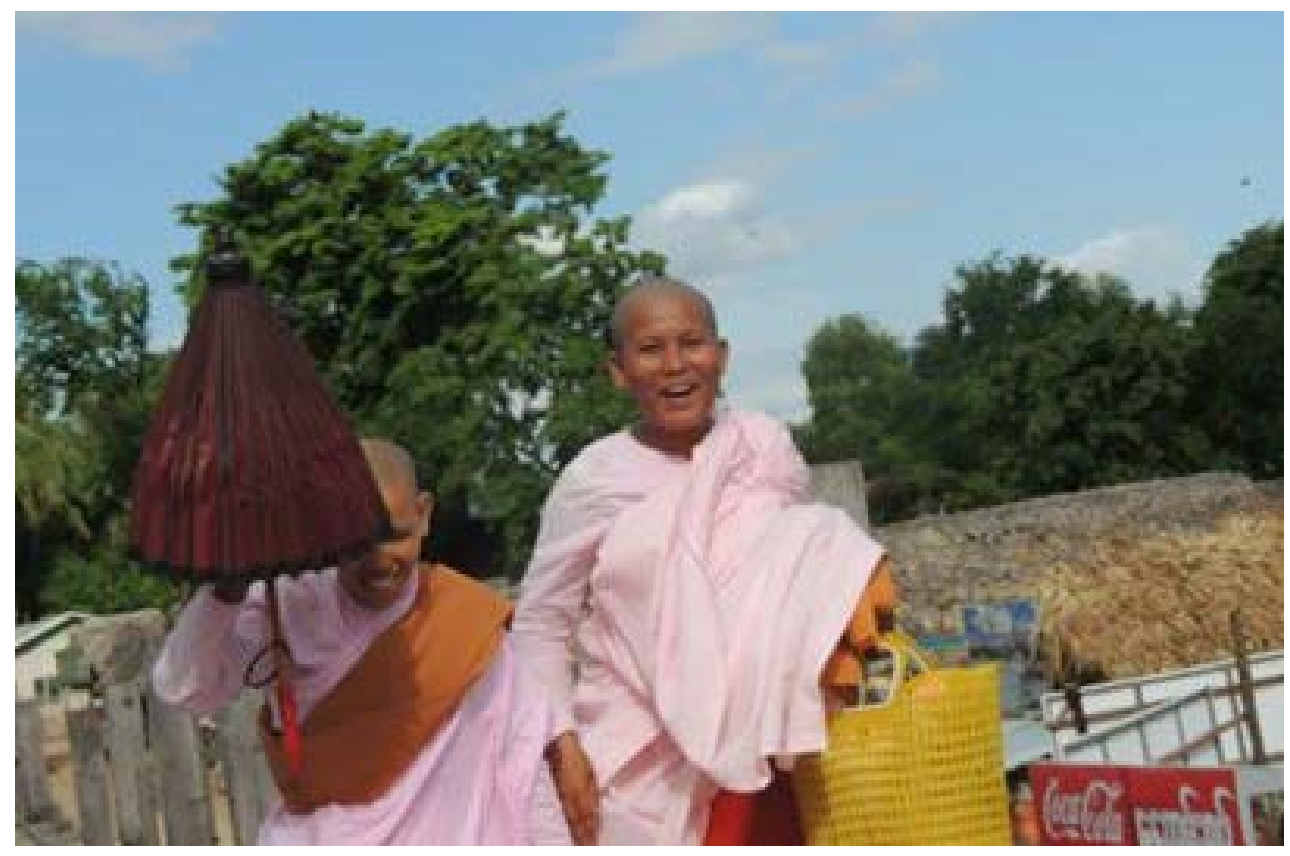

Figure 2. The moment I met Ma Candasiri

There were moments like these when I saw the immense amount of respect both lay and monastic women held for men despite their disagreement on values and actions. I met Candasiri while walking down U Bein Bridge (see Figure 2). It was a moment that instantaneously felt magical. I was trying to capture a picture of her and another nun holding their umbrella as they walked down the bridge and as soon as I snapped the shot a gust of wind almost knocked them and the umbrella off the bridge. At that moment we made eye contact and began to giggle uncontrollably. I laughed with her endlessly for the next month. She is 40 years old and has been a nun for 24 years. Her parents were rice and sesame seed farmers from the Magway region where General Aung San was born. Her mother died from a head injury when she was 8 years old and her father was an alcoholic who died when she was 23. She has four siblings, three brothers and one sister. Two of her brothers died. One died at the age of 7 of TB and the other died from a stroke as an adult. 
Upon meeting her, she invited us to her university: Sitagu International Buddhist Academy located in Sagaing. She wanted us to come and hear the chancellor speak so that she could introduce us after the lecture. We arrived at Sitagu early the next morning; it turns out we were watching the welcoming of the new class. The room was divided equally among monks and nuns, which was refreshing. The day before, during a lunch at Sakyadhita several men invasively came to the front of the temple while we were praying with the nuns and sat in front of all of us although there was little room available for them to do so. As a westerner I found this so incredibly rude. However, Vedarki, a 35-year-old nun at Sakyadhita, explained that they were there with the donors and as males they were to sit in front of the women inside the temple. At this point it was still shocking that a layman had more entitlement to sit closer to the Buddha statue than a nun who had devoted her entire life to Buddhism, simply because he is a male. The female donors all sat with the nuns and behind them. This was not the case at Sitagu. The ceremony involved a dhamma talk by the chancellor and several revered abbots from other parts of Myanmar. At the end of the ceremony, Candasiri lit up the room, as usual, with her beautiful smile when she realized we had been watching the whole three-hour long ceremony behind her. She was so happy to see us and she proceeded to introduce us to all her professors (monks) and even the chancellor, Ashin Nyanissara, an interesting subject whose actions and intentions within the Myanmar Buddhist community are somewhat ambivalent. 


\section{The Curse of Womanhood within Buddhism in Myanmar}

One reoccurring narrative I heard often in Myanmar among women was the mention of hope to reincarnate as a male in the next life. When Candasiri introduced us to the chancellor at Sitagu, he was very dismissive of us. There was little respect given to Candasiri while she spoke and at one point he waved his hand in a manner that seemed as if he was swatting her away. I saw this often in monk and nun interactions, as I will discuss in further detail in the next chapter. However, all the men and monks in Myanmar treated my research partner and me with the utmost respect and kindness. They were usually eager to converse with us, connect with us on social media and even take pictures with us. The whole experience was pleasant and we were treated like what sometimes uncomfortably felt like royalty. Was it because we were light skinned, western and blond? Many factors seem to point this way.

During the hot summer days, at any given moment near a body of water, whether it was the Ayeyarwady River or Thaungthaman Lake, women would bathe wearing longyis (a fabric folded and tucked in a bandeau style across their bodies and below the knees like a sarong). I was told by one of my subjects that many women in Myanmar bathe wearing these robes despite public or private facilities or monastic or laywoman status. I later had the privilege to witness several nuns and monks bathe this way while conducting my research. Women in Myanmar do not smoke or drink alcohol. During my visit I did not see a single local woman drinking alcohol. I did see one older woman smoking a cigar crouched over in a corner behind a tree during a visit to the waterfalls of Pyin Oo Lwin. I was told by two of my subjects, a monk and a laywoman, that it is frowned upon to see a woman engage in such activities. However, the same does not 
apply to men. Many times, while having a drink or a smoke myself, I was approached by locals and monastics to converse and they showed no judgment toward my actions. I was told by one of my subjects, Panna Jota, that they did not expect the same behavior from a foreign woman as they do a local.

I was introduced to a lay Buddhist woman who observed the five precepts. ${ }^{4}$ Her father asked me at what age women leave the home in the United States. When I explained the process of American adulthood and leaving for college he was appalled and stated that his daughter at the age of 30 was still very much under his rule, a virgin and could not leave the home unaccompanied. She must always be with a man or one of her sisters. I asked him if this was her choice or his and he stated that was just the way it is for her own protection and well-being. The father did not even consider whether or not she desired to be controlled by him. Later, the daughter confided in me that she had fallen madly in love with a Christian man of African descent much older than she, and that she mourns she will never pursue this relationship until her parents have passed away. When I asked what the problem was exactly, she stated that her father would never forgive her for falling in love with a black man who is not Buddhist. I was beside myself when she and her father both celebrated my independence as a single parent and graduate student. It was clear that these rules only apply to those who are Buddhists and live in Myanmar. My independence as an American raised in a secular home suddenly felt more like a privilege.

\footnotetext{
${ }^{4}$ Details have been modified to protect my subjects.
} 
While the heat waves in Myanmar reached up to 107 degrees Fahrenheit, we began to yearn for bodies of water to cool down, as we do back home in Miami, Florida. For a fee, we went swimming at the Mandalay Hill Resort, a prestigious hotel, to cool off and bronze our skin. A few days later, Daw Nang approached me quietly and handed me two tubs of skin lightening thanaka. Although we had been gifted other containers of thanaka by monks and nuns, this one was different as it boasted having a skin bleaching agent. I thanked her for it and asked what kind of thanaka it was. She explained that our skin looked "dirty and too dark" from our sun tanning. I laughed and told her that the purpose of tanning was to darken the skin, and that we thoroughly enjoyed having suntanned skin. She nodded and smiled, but later in the day called one of her maids to apply the thanaka on our faces before we all went out together, even though my research partner made it clear she did not want to put thanaka on her face.

I heard this view often even from people whose skin was dark. During my stay I was also struck by the advertisement of skin bleaching agents within thanaka and face cleansers such as the brand Nivea. When I searched for those same products in the states, they were unavailable and only for sale in Japan, China, India, Thailand and Myanmar. It became apparent that these cultures heavily encourage keeping the skin pale and light as a beauty standard. This brings up questions for me about how influential these norms are in regards to two systems of subordination, one based on sex and the other on skin color.

Furthermore, I wondered how it makes women from ethnic minorities, who tend to have darker skin, feel. The use of thanaka is widespread. The majority of women and children use it on their face daily. Men use it as well, but it was less common to see males wearing it. Was this because males are so satisfied with their male agency in society that 
they are less concerned about their categorization in terms of skin color? Perhaps being male, dark skinned and Buddhist is less concerning than female, dark and Buddhist or male, dark skinned and Muslim.

Candasiri is a beautiful, olive-skinned nun. As a matter fact, many of the nuns at Thila Nyunt had olive skin. Often they would caress the lightest areas of my forearms and tell me how "hla de" (beautiful) my skin color was. I would laugh and explain to them how far some women in the United States go to remain tan through excessive UV exposure or spray tanning. When I told them my father was Afro-Cuban and my mother a blonde light-skinned Spaniard-Cuban they told me how fortunate I was to turn out lighter. Again, the term “dirty” was used to describe darker skin complexion. Candasiri explained that in Myanmar the darker your skin the closer you are to the lower class. She then told me she must have had a turbulent past life, since she reincarnated as a dark poor woman in this life. She hoped to change her karmic outcomes with her life as a nun this time around. It was clear that to be a woman and to be dark were curses understood in terms of kamma. The issues of skin tone and the anti-feminine within monasticism are multi-vocal and heavily preached by anti-Muslim nationalists. Simultaneously, we have women who desire to come back as men because Burmese Buddhism teaches them that to be a woman is to lead a life of subordination. As I have witnessed in the past, these ideas stick with them even when they flee the country.

In 2013, I worked with Burmese refugees in Thailand. On several occasions, my students at the orphanage-sponsored primary school bullied a darker skinned Rohingya refugee and called her racial obscenities. When the child died of TB some of the children felt an immense amount of guilt. I created an anti-bullying workshop for the students who 
shared the belief that to have dark skin was to be a lower caste other. Even though these children were at the time practicing neo-humanism and did not receive Buddhist dhamma education they carried the stigmas provided by the society they came from in Myanmar.

To have dark skin is to be associated with the lower caste and poverty. From my own observations, it was obvious that ethnic minorities (particularly indigenous peoples of Myanmar) are struggling with poverty as are the Rohingya who are also much darker and referred to as "boat people" by most. The lighter skinned locals with Chinese ancestry are mostly middle class, like Daw Nang. This structure is similar to what we see in the U.S. where Blacks, Hispanics and "Native Americans" are a minority and the whites are the majority and predominate the middle and upper class. Like American minorities, these minorities in Myanmar suffer all forms of racism (social, environmental and economic). As a minority myself, I was previously a victim of my own ghetto environment and understand the outcomes of some of the lives of these minorities because opportunity is not readily available. This leads many women into prostitution, human trafficking and other forms of violence. Buddhist dhamma practice in Myanmar would be more supportive of women if they provided full agency for those women who so desperately need it, as they do for men who seek refuge in the sangha.

Puntarigivat, a Buddhist scholar from Thailand, touches on these issues when voicing his concerns for the mae ji's of Thailand suffering the same fate as Burmese nuns in terms of ordination and lack of funding, education and adequate living conditions. He says, “The replacement of mae ji by a Bhikkhunī institution would greatly raise women's status at the core of Thai culture and would begin to address many of women's problems in Thailand - including poverty, child abuse, and prostitution” (Puntarigvivat 2001, 225). 
Like saya-leis, mae ji's are less valuable fields of merit for the community and are therefore, "marginalized, undereducated, and economically unsupported and alienated in present day Thai society,” (qtd. in Puntarigvivat 2001, 225). When we analyze the cause of women's status as nuns we can deduce that kamma and patriarchal society are equally responsible. A woman's kamma is allegedly the reason why she suffers (as it is for males) but to be a woman, in itself, is viewed as negative kamma. This is crucial to the development of women's self-esteem, especially in circumstances in which they are born into poverty. Their desperation to flee poverty and provide for their families at times leads them to prostitution. I chose this analysis because many of the women fleeing Myanmar whom I worked with in Thailand also were trafficked and subject to prostitution by force.

One problem with Myanmar's and Thailand's rural areas is the lack of access females have to education. While boys are encouraged to become novices when their families cannot afford education, little girls do not have that option. Most nunneries in Myanmar will not take child nuns because they cannot afford it. Most of the kids in rural areas turn out to be monks in the temples located in the central areas. Monastic education provides them with a future. So what happens to little girls who are uneducated in a country like Myanmar? They become factory workers exploited for minimal wages and extreme work conditions due to the pressures of filial piety and consumerism. When wages are not enough or not available, women turn to prostitution and sex-related businesses (Puntarigvivat 2001, 234). A woman who feels pressured to contribute to the well-being of her family and lacks education will seek desperate measures to make ends meet. When they seek spiritual guidance and healing, the monks refuse to speak about 
sexually related troubles and there are no adequate escape routes for them as monastics. Though to be a saya-lei would be preferable to prostitution, even if it is a life of poverty, it does not allow women to contribute to the support of their families, only perhaps to relieve families of the burden of their support. However, if a bhikkhunī order were legitimized, it would make parents steer their daughters toward that option, as they send sons to become monks. These women who become prostitutes believe that they are destined to be prostitutes and lower class citizens because it is their karmic retribution. They feel like they are fulfilling a karmic fate and must depend on males to survive in society without education by whatever means.

\section{Conclusion}

Buddhist texts may not even reflect the actual words of the Buddha, but the words of the men who later selected, wrote and translated them and had problems with accepting women as equals in the monastic order. Today these texts go through yet an additional patriarchal filter, the monks who interpret the texts in the present. It seems as if kamma serves as a tool to oppress minorities and women. Although I do not want to be an essentialist and address the literal meaning of kamma in my work, I feel that to throw it around as a weapon or tool of power regimes fulfills a desire to oppress and runs counter to Buddhist values. If karmic retribution is in fact a Buddhist's destiny, schadenfreude will be the deciding factor of the oppressor's karmic outcome.

During my stay in Myanmar, the saya-leis assumed a more legitimate form of Theravāda Buddhism than the 969 monks insofar as they did not support violence and judgment based on religion, sex or ethnicity. In the following chapters I will discuss my 
experiences with the monks of the 969 Movement. The nuns are not given adequate government support because their legitimacy as bhikkhunīs is not legally accepted. Yet, the 969 monks fail to abide by the laws bhikkhus are ruled by. Reviving the bhikkhuni sangha would not just elevate women's status in society, but it would raise it in the domestic environment as well. It would provide an additional route for women who in desperation turn to prostitution and trafficking, something that is common in Myanmar and Southeast Asia. Female ordination would strengthen Theravāda Buddhism, as it will appeal to many more due to its success among more genders and classes. Buddhism can exist as a religion of equality, compassion and social engagement. However, the control over women's bodies, the claim of karmic punishment in race and gender, and religious nationalism do not seem to fit into a Buddhist model of enlightenment much less one of compassion. 


\section{CHAPTER 2}

The Paradox of Ordination and Religious Nationalism:

Theravāda Buddhist Female Monastics and the 969 Movement in Myanmar The current government, The Union Solidarity and Development Party (USDP), sanctions the actions of the radical, nationalist group of Buddhist monks known as the 969 Movement, encouraging ongoing violence against the Muslim Rohingya. The 969’s leader, U Ashin Wirathu, intimated to me in an interview that the Rohingya target Buddhist women for rape, and then forcibly marry and convert them to Islam. Though the government and Wirathu profess concern for the welfare of Burmese women, that concern does not extend to the education, health care and nutrition available to women in the monastic establishment. Furthermore, as I will discuss in deeper detail in the upcoming chapters, the alarming ongoing rapes of ethnic minority women by military officials in the Shan State are not acknowledged either. When I initially approached this topic, it seemed that inciting violence against an ethnic group violates the Vinaya and contradicts the monastic precept of ahimsa, or non-violence. This chapter focuses on 969's anti-Muslim rhetoric and their statements on women’s capacities, particularly for nunhood. I begin by examining one non-969 monk’s reception of these statements, then look at how Wirathu himself understands his political agenda; finally, I examine the way that one monk who supports the 969 reconciles the group’s statements with his ambitions as a Buddhist monk.

The 969's claim that Buddhist women require protection from Muslim men is equivalent to saying that women are the chief means by which Islam threatens the nation. Such statements justifying violence against Muslims are fundamentally related to 
misogyny and control of women. Women who seek full ordination are not granted the right, as it is part and parcel of the government's and sangha's attempt to control all Burmese women, while also defining who is acceptably Burmese. Additionally, decisions are consistently being made for these women in the name of "women's rights" when in fact they are propagating oppressive narratives and societal norms that contradict Buddhist foundations practiced by Theravāda Buddhists worldwide. During my time in Myanmar, however, I heard many monks and laypeople make normative claims about the nature of authority by exemplary action, without necessary reference to written rules.

Although Myanmar is no longer under the rule of the military junta, ethnic cleansing continues to occur in the Rakhine State toward the Rohingya, which I outline with more detail in Chapter 3. It is difficult to accept that the 969 Movement is truly concerned about the disintegration of Buddhist culture when there are no documented grounds for fear of a jihadist movement by the Rohingya in Myanmar. I posit that Buddhism is being used as a tool to oppress both ethnic and religious minorities and women to exert control over the whole nation and forestall the democratization process.

In this chapter, I introduce U Panna Jota, U Ashin Wirathu and U Ashin Candavara. Panna Jota is a humble and liberal monk, while Wirathu and Candavara provided perspectives on the 969 Movement, the former as its leader, the latter, a monk testifying to the movement's appeal. I will discuss the month-long series of interviews performed in the summer of 2015, referring to their views of women and saya-leis in Myanmar, the ban on interreligious marriage and their views of the Rohingya and Muslim minorities throughout the country. 


\section{The 969 Movement-From Outlaws to Cronies}

In 2001, Ashin Wirathu was sentenced to 25 years in prison for his involvement in the anti-Muslim group 969. He was imprisoned chiefly for his sermons, but was released on amnesty in 2012. He is now the group’s leader. The 969 is a numerological reference created to counter the Islamic numerological representation 786, which stands for Bismillah ar-Rahman ar-Rahim, ("in the name of Allah, the compassionate, the merciful”). The three digits “969” together are a symbol of the Three Jewels of Buddhism. The first nine represents the nine noble attributes of the Buddha, the six indicates the attributes of the dhamma; the last nine signifies the attributes of the Buddhist sangha. For years, 786 has been displayed on Muslim-owned groceries and restaurants to let the Muslim community know they serve halal food. In response, the symbol 969 encouraged Burmese to "buy Buddhist.” Connections with the junta are also apparent, as Gen. Ne Win (Head of State, 1962-1981), who relied heavily on astrology for his decisions, always favored the number 9 and considered it his lucky number (Inside Burma 1997). Additionally, Than Shwe, the superstitious gambling junta leader (1992 2011) responsible for the murder of hundreds of monks during the Saffron Revolution, ${ }^{5}$ believed the digits 786, totaling 21 when added together, meant that Islam would dominate the world in the $21^{\text {st }}$ century (Coclanis 2013).

\footnotetext{
${ }^{5}$ Saffron Revolution was the best-known protest of Myanmar's monks and nuns against the junta. In September 2007 a price hike in fuel initiated a response from the monastic community, in turn it led to a nationwide protest with thousands of supporters.
} 
The 969 Movement is not the majority in Myanmar, but they have strong backing from the USDP and Buddhist sangha. Wirathu is a teacher at the New Ma Soe Yein Monastery in Mandalay. There, he has access to 2,500 students, including novices and lay females. His videos reach up to 60,000 students via YouTube and 150,000 citizens on Facebook. From my experience watching the young novices cling to Wirathu's every word and exulting in his celebrity status, there is no doubt the movement will continue to pick up force. In terms of the Vinaya, this movement is a violation of the rule about schisms, which states that bhikkhus shall not create a schism in the sangha. Additionally, any monks who follow a monk who created a schism are also in violation of the Vinaya (Pruitt and Norman 2001, 17).

In addition to the direct influence at the monastery and social media, Wirathu has strong support from the (now former) President Thein Sein and Sann Sint (former lieutenant in junta army and minister of religious affairs for the USDP), (Marshall 2013). Ex General Khin Nyunt who had a military strategic plan to raise Myanmar's population to 100 million from 54 million and subjected the Muslim Rohingya to population control measures, also supports Wirathu's agenda and has been seen visiting him on numerous occasions (Zarni, 2014). When rallying for the ban on interreligious marriage Wirathu and Ma Ba Tha collected over 2.5 million signatures (Walton and Hayward 2014, 16).

In an interview with Tin Aung Kyaw, Wirathu stated, "Snakes are poisonous wherever they are. You cannot underestimate a snake just because there is only one. It is dangerous wherever it is. Muslims are just like that” (Gier 2014, 67). This analogy resonates with the misogynist narrative represented in the Vinaya referencing women, "It would be better, foolish man, to put your male organ into the mouth of a terrible and 
poisonous snake than into a woman” (Satha-Anand 2001, 115-116). This statement was recorded as a conversation between the Buddha and a monk who wanted to revert back to worldly life. These kinds of narratives demonize women and later provide hateful analogies to be used against others.

When holding town meetings in Mandalay, Wirathu stimulates his listeners to initiate the depopulation of the Muslim community, whom he claims "Rape, marry and convert our Buddhist women” (Mantra of Rage 2013). For a monk to claim ownership of a woman, even collective ownership, is interesting. Here we see Buddhism working on a "cultural” level in his thinking, as an identity. On a religious level, Wirathu is acting like clergy to a population he understands to be uniformly "Buddhist" in its lay and monastic configuration. In this sense, the idea of having a religious "identity" that adheres to a person regardless of their specific beliefs and practices makes them, in Wirathu's eyes, culturally Buddhist, and without regard for whether they are practicing Buddhism well or not. His "convert" claim seems to point this way: one who becomes or marries a Muslim loses her Burmese identity.

Buddhist women who experience sexual violence are often told that they are unable to seek spiritual guidance because the monks lack the experience to help them. In fact, they often hear that confiding in a monk can pose a risk for the monk's safety and pose a threat to a monk's vow of celibacy (Khuankaew 2007, 176). Wirathu, with support from President Thein Sein, successfully lobbied for the ban on interreligious marriage. For a monk to dictate the choices a woman makes in respect to personal relationships is seen as the duty of community leaders and clergy, so they understand it as well within their right to make these claims. Wirathu also utilizes the experiences of Indonesian, 
Malaysian and Indian Islamizations as examples of what Muslims, who comprise only 4\% of Myanmar's population, are allegedly capable of; hence the fear-inducing speeches

about the conversion of Buddhist women. These speeches entice the Buddhist community to ransack and destroy Muslim businesses, mosques and villages (Coclanis 2013). There is a great emphasis on preserving Buddhism in his hate-filled speeches. Additionally, while it is argued that Indonesian government is officially religiously neutral, it does go out of its way not to anger the $87 \%$ Muslim population in defending the rights of other religions. India does the same to a lesser extent, due to its religious majority being Hindu. One can argue that Malaysia’s Islamization process was successful for years, but is beginning to be challenged.

\section{U Panna Jota - Founder of TPP}

On the second day in Myanmar, we walked onto the grounds of New Ma Soe Yein Monastery and were kindly greeted by a monk named U Panna Jota. Immediately, he began to inform us about the grounds, the teachers and how many novices and monks live there and attend dhamma classes (about 2,500). We arrived about half an hour before lunch and he insisted we have lunch with the schoolteachers. When we entered the facility we were served an array of traditional Burmese dishes and pastries. Panna Jota went above and beyond to ensure we felt at home. He explained what each dish was made of and its origin.

After lunch, several of his monastic colleagues and novice students were sitting under a tree where he says they like to discuss current events and politics. From then on this was called “The Politic Tree.” There, we had many conversations with monks about 
the current state of Myanmar's government and sangha. On this particular day, one monk in his late 30’s asked me how Myanmar could turn toward democracy, "like the United States." He asked about our education system and agreed that secular education is key to a country's evolution. He seemed overwhelmed with emotion as he told me his experiences with Myanmar's education system before and after the 8888 uprisings. ${ }^{6}$ I realized later that this was a common point of reference most monks and nuns I engaged with return to when they spoke of the events that lead to a life of monasticism. This brings up questions for me of authenticity in respect to Buddhist beliefs versus survival. I will address this later in the chapter when I have laid out all my subject's details.

Panna Jota then led us to the back of the hostels where they have created a relaxation area filled with greenery and flowers. There were several benches facing the canal. A resident monk began creating a miniature clay village with golden pagodas, mountains and homes. It was a beautiful and imaginative sight. I saw several betel stained spit buckets and cigarette boxes there as well. I spoke with Panna Jota for a few hours. Over the next month, this was our official meeting point to spend hours talking. We spoke about astrology, women’s rights, Panna Jota's life before and after monasticism, the Dhammapada and the Abhidhamma. I did not just get to know Panna Jota, he got to know me and he helped me understand Myanmar, Buddhist dhamma and even myself a

\footnotetext{
6 In 1988, the growing resentment towards military rule caused by police brutality, economic mismanagement and corruption within the government lead to widespread pro-democracy demonstrations by students in Rangoon on August 8, 1988 ('8888'). Hundreds of thousands of monks, young children, university students, housewives, and doctors demonstrated against the regime. The uprising ended on 18 September 1988, after a bloody military coup by the State Law and Order Restoration Council (SLORC). Thousands of people were reportedly killed by the military during the uprising, although Burmese authorities put the figure at around 350 people killed (Oxford Burma Alliance 2013).
} 
bit more as the weeks passed. We never had a moment of silence between us, unless we locked eyes and practiced noble silence during awkward moments of culture shock and misogynist comments made by others that only he understood from my feminist perspective.

There was something about his calm demeanor and kind voice that provided comfort and trust. He was tolerant and flexible when answering my questions and he always remained consistent with the rules of the Vinaya as I expected from a monk. He was knowledgeable in Buddhist suttas and history and truly a master of the dhamma. He was bashful and turned bright red when we celebrated his intelligence and kindness. This humble monk is also a staunch feminist, something that was unexpected due to the widespread negative attitudes toward women in Myanmar and in the majority of the Pāli canon. On one occasion, he read one of his favorite quotes by Abigail Adams, "Remember, all men would be tyrants if they could. If particular care and attention is not paid to the ladies, we are determined to foment a rebellion, and will not hold ourselves bound by any laws in which we have no voice, or representation.” Although I have tried to train my mind not to have bias, there was a dreaded expectation in the back of my mind about the monks at New Ma Soe Yein Monastery. This was a media-fueled expectation, about encountering the monks of the 969 Movement. When one reads the articles published about Ashin Wirathu and 969, New Ma Soe Yein is often mentioned as the 969 leaders' home base. Wirathu is a teacher there, but not all the monks at New Ma Soe Yein support the 969 Movement. This became very clear after my first Politic Tree talk with Panna Jota. 
We began to talk about Aung San Suu Kyi and the upcoming elections. He had high hopes that the parliament would allow her to officially run for the presidency, but a few days after he voiced this hope the parliament denied her the right. Most of my subjects love Suu Kyi, even my borderline nationalist Burmese host mother, Daw Nang. The only person I interviewed who did not like Suu Kyi was Wirathu. Panna Jota told us that Wirathu used to be a fan of Suu Kyi until she began to show interest in providing aid to the Muslim minorities. For Wirathu, in order to run the country one must possess a nationalist mentality to protect the people from losing their Buddhist culture and values. Panna Jota said that Wirathu thinks that, as a mother of two British men and supporter of Muslim refugees, she is not fit to run Myanmar. On the day the parliament decided that Suu Kyi would not be allowed to run as the NLD’s candidate, Wirathu made a Facebook post about his “victory” against Suu Kyi.

I asked Panna Jota what he thinks is in store for the future of Myanmar's government. As he took a bite of the pizza we ordered (from the only American style pizza place in Mandalay) he said, “I think the only hope we have left is the TPP.”note to interview When I asked him what the TPP was he smiled and said, “The Pizza Party.” Panna Jota said that the government claims to be Buddhist, but they have no idea how to practice authentic Buddhist compassion and values. He stated that the monastery made a lot of changes when the former abbot, Ven. Rajadhammabhivamsa, died. The new abbot, Ven. Kesarabhivamsa, has government ties, which is specifically why Wirathu gets away with giving such hateful speeches about the Muslim community. For Panna Jota (2015),

Nationalism narrows our views and Myanmar remains just a nation instead of a place where we can attain more knowledge and practice compassion. That would be a true Buddhist nation. Instead, it is a political war waging 
hatred against people who are not the same as the majority. The people here don't want nibbana, they just crave power and material gains. This is evidence that they do not truly understand the circle of life.

This statement resonates well with a statement Daw Nang made in reference to women in Myanmar. She said, "Every woman should want to come back as a man.”note Daw Nang's statement reflects the desire to be powerful. In Myanmar being a man is power. It is entrenched in the fabric of society.

\section{Tea Time with Ashin Wirathu, the "Buddhist Terror"}

I asked Panna Jota if it was possible for me to interview Wirathu. His initial reaction was laughter. He said, “Are you sure you want to talk to him? He will not speak to you about dhamma. He is only willing to speak about politics. If that is ok with you, I will ask him.” Immediately we agreed and he made a few phone calls. I had my interview. However, my first encounter with Wirathu was prior to that day, during my second visit to the monastery. I was wandering the grounds taking photos of the monks when I peeked into his classroom through a window. As I was quietly snapping photos, he stopped the classroom sutta recitation turned to me and said, "You do not have to hide, come in, sit, take photos." I took many pictures and videos of him teaching his students the sutta recitation.

While I was taking pictures, I was intrigued by his tattoos. I snapped a couple photos of a peacock tattoo he has on his arm. Later, I confirmed that it is the NLD's democratic symbol; Wirathu flashed a charismatic smile and pretended to scratch the tattoo off when I mentioned it. He claims he once respected Aung San Suu Kyi, but then she turned against them by claiming that The Association of Protection of Race and 
Religion (Ma Ba Tha) is a violation of human rights. For Wirathu, this means she supports the Muslim minorities and not the Buddhist Nationalists. This allegation stems from Suu Kyi's reference to the human rights violations made under the authority of several laws passed by the parliament during my stay this summer. One is the Population Control Healthcare Bill, which requires women to keep births three years apart. The Association for the Protection of Race and Religion (Ma Ba Tha, in Burmese) created laws said to be put in play for the, "protection of Buddhist women.” The law is specifically directed at Buddhist women who intend to marry non-Buddhists and applies to all women over 18 (Walton \& Hayward 2014, 16). This requires all marriages to be announced in a public forum during the application process, where the family can make objections for 14 days. If any objections are made they can be taken to the local court. It also requires all women to receive consent from their parents to marry non-Buddhists. In terms of "protection,” as the Ma Ba Tha and 969 supporters claim, the law is designed for non-Buddhist grooms to respect their Buddhist wives' religious practice by allowing them to display imagery in their home and allow participation in Buddhist ceremonies and events. The husband is also bound to respect Buddhism and never violate the terms of the marriage by speaking, writing or behaving with any intent contradictory to Buddhism. Violating these provisions result in divorce, a fine owed to the wife, no custodial rights to the children and loss of any jointly purchased property. According to Human Rights watch, “Offenses against Buddhism could bring charges under the Penal Code for insulting religion, specifically sections 295 and 295(a), which impose prison terms of two to four years for violations.” The law is also now applicable to already married interfaith couples and they are requested to register their marriage (Human 
Rights Watch 2015). However, these laws contravene Myanmar’s treaty obligations under international law. According to The International Covenant on Civil and Political Rights, families should be founded without discrimination of religious practice (United Nations 1976).

I discussed these human rights and gender inequality issues with my subjects. The responses did not vary among the nationalists, as they were unanimously adamant about the Muslim other’s intentions to destroy Buddhism throughout the world, predictably through violence and marriage. The more liberal subjects tend to strongly oppose this view, but feel defeated, without the means to make a change among the community due to their lack of power and financial freedom. Although the 969 supporters veer toward nationalism, my interviewees as a group expressed several variations of political stances and behaviors. None of these possibilities trace back to an admitted desire to oppress and hate. One thing all the subjects have in common is at one point or another they have all been victims of the Burmese government's instability in the last fifty years. In the case of Wirathu, he was clear that he did not want to speak about personal matters in terms of his upbringing or even about the Buddhist dhamma. Therefore, my analyses of his reasons for anti-Muslim attitude are based on our politically -focused interview that took place June 26, 2015 at New Ma Soe Yein Monastery.

Wirathu asked Panna Jota to inform me that he was making an exception to speak to me. Usually he only speaks to the press. He made it clear he did not want to speak to me about Buddhism. He wanted to speak about politics. When I walked into his office I was taken aback. There was a wall enshrined with pictures of himself with various political and religious leaders, including Sitagu's chancellor, Ashin Nyanissara. I have 
never seen so many self-portraits in monastic dwellings. Panna Jota also pointed out that a group picture of all the teachers of New Ma Soe Yein is not displayed. Yet the pictures displayed self-portraits and pictures of him with political and religious leaders.

Wirathu was the first to ask a question, "Do you work for the CIA?” I smiled and said no. He responded, “Well, I'm not afraid of the CIA. I just ask all Americans if they are spies” (Wirathu 2015). He then asked for our names and address. We signed a guestbook accordingly. My first question was if he thought that saya-leis should have the right to be ordained as bhikkhunī. He said, yes. He agreed that say-leis should be bhikkhuniss. I then asked if he saw the new law proposing a ban on interreligious marriage for Buddhist women to be oppressive toward Myanmar women. He had just arrived from lobbying in support of it in Yangon. He said this is not a ban on marriage. I asked if he viewed the ban as a male domination over what women choose to do with their lives and bodies. He said this law was created specifically to protect women from losing their religion, religious rights and properties acquired prior to marriage. I then asked, what if the women making the choice to marry do not care about these things? He said, that it then does not apply to them. It only applies to the women who want to remain Buddhist. My next question was, "If you feel Buddhist women need protection, why are the same efforts that are put forth on preventing them from interreligious marriage not being used to help revive the bhikkhunī order?” He said that it is difficult for saya-leis to become bhikkhunīs because there are more rules presented to a bhikkhunī than saya-lei. He said bhikkhunīs are more like monks spiritually, which is very difficult for a saya-lei to achieve. 
I then pointed out that monks are able to follow the rules and be a part of the sangha, so what is the difference? He said that out of 100 saya-leis, only one would possess the ability to achieve bhikkhunī practice. He stated that the teachings and responsibilities given to a bhikkhunī are beyond the teachings taught to a saya-lei and therefore taking on this task is too much work for them. This is peculiar coming from a monk who is known for his impertinent calumnies and loss of temperament during speeches. There was an incident with the U.N. Special Rapporteur, Yanghee Lee, in which he publicly called her a "whore” for defending the "kalars.” 7 Yanghee Lee had been visiting Myanmar in January 2015 to address the aforementioned marriage legislation that violated the rights of women and minorities because of the tensions it would cause among the people. According to Eleven Media Group, his exact words were, "We have explained about the race protection law, but the bitch [Lee] criticized the laws without studying them properly. Don't assume that you are a respectable person because of your position. For us, you are a whore” (Eleven Myanmar 2015). I confirmed this by playing the video for a monk who translated the speech for me. Wirathu stands by his statements and refuses to issue an apology, despite U.N. High Commissioner for Human Rights Zeid Ra'ad Al Hussein’s request for political leaders to condemn Wirathu for using such sexist and insulting language to a U.N. representative. I asked Wirathu if he sees any contradictions in the speeches he delivers to the people when speaking about the Muslim community and the laws presented to him as a monk. He said that he does not go against the Vinaya at all. He is defending Buddhism. He said that most preachers preach

\footnotetext{
${ }^{7}$ Kalar is a derogatory word used to refer to Indians or dark skinned people in Myanmar.
} 
about love and kindness, but he preaches about protection of Buddhism and maintaining the practice among the Myanmar people.

Wirathu's hate-filled discourse is a contributing factor to Myanmar's widespread fear of Muslims. In front of his quarters at New Ma Soe Yein, there are bulletins filled with Photoshopped images depicting violence against Buddhists and Christians by Muslims when in fact some are photos of Southern Thailand's Buddhist war against Muslims. They read fake headlines depicting sacrifices of "Christian martyrs.” One picture in particular I recognized as a photo of ISIS beheading Muslims in Syria, not "Christian American Martyrs," as it was labeled. Wirathu has preached "whatever [Muslims] do, they do it from their Islamic point of view.” In an interview with Tin Aung Kyaw (2013), Wirathu stated, "Islam is a dangerous and fearful poison that is severe enough to eradicate all civilization... Muslims are like the African carp. They breed quickly and they are very violent and they eat their own kind.” This is a contradictory dialogue considering Wirathu's claim to adhere to right speech in accordance with the Buddha's nine attributes. Instead, he claims his context is strictly enforcing nationalism among the Buddhists and not producing hate-speech geared at igniting violence (Walton and Hayward 2014).

During interviews with Win Tin, the late staunch NLD supporter, journalist and activist, Wirathu mentions on several occasions the lack of intelligence among the Burmese citizens and the inability of Suu Kyi to lead Myanmar to democracy (Win Tin 2014). For me, his speech evinces his superiority complex regarding both Burmese citizens and Suu Kyi as a woman. Other Wirathu speeches seem to imply a mentality that thinks of the feminine as subordinate. Statements like the ones about the saya-leis being 
incapable of behaving as monks do and calling Yaghee Lee a whore can attest to this. This is not surprising since Theravāda Buddhist practice adheres to the Garudhamma, making even the oldest monastic women subordinate to the youngest monks. This was clear through my experiences watching the Thila Nyunt nunnery's headmaster bow to young monks.

When I mentioned that in the United States I have met several bhikkhunī teachers, Wirathu responded that it is possible for foreigners, but in Myanmar saya-leis cannot attain "fame" like a foreign bhikkhunī through Buddhist teachings, but instead by helping others. I found this particularly interesting because throughout my research I have learned that most monks, nuns and democratic laypeople insist that what Myanmar is in most dire need of is education. This statement of Wirathu's can be interpreted this way, but I also would like to point out that he used the word fame. Fame is a word that Wirathu uses often, as do the monks and nuns with whom I spoke about him. Wirathu and those around him often measure success in terms of fame. In this case he used it to measure bhikkhunī credibility. For Wirathu, the word fame connects a person to importance. He uses it to describe things that are important because of their popularity and not credentials. According to Panna Jota and several other monks I met at New Ma Soe Yein, Wirathu does not respect monks who do not preach nationalism. For him, preaching nationalism is spreading and defending Buddhism. He believes that his anti-Muslim diatribes are a service to Buddhism.

Wirathu then explained to me that action is more important than creating goals. He meant that if a saya-lei truly wants to be a bhikkhuni, then she should practice the ten precepts like a bhikkhunī. I agree that practice is within the self, but I do find this 
statement problematic in terms of what is available for the saya-leis of Myanmar. While the majority of the male novices I encountered at the monastery eat like kings and receive prepared meals daily, saya-leis are handed raw rice and very little money on collection days (see Chapter 1). They also do not have access to the Buddhist education that the majority of monks have. Many nuns are forced to do housework at the nunnery and help raise the younger nuns, instead of having the opportunity to learn the dhamma. Taking on all ten precepts would be dependent upon having living conditions comparable to those that monks have. However, that privilege comes with government backing and foreign donors. Until there is a national agreement from the sangha that saya-leis are capable of equal achievement with monks, this is far from possible.

We then began to discuss his views toward the Muslim community, specifically the Rohingya. I wanted to know why he compares the Rohingya to ISIS in his speeches. They do not have weapons or power and they are not trying to convert anyone to Islam. For the most part, the Rohingya receive more media attention from Islamic groups such as the Afghan Taliban, al-Shabaab and the Pakistan Taliban because of Wirathu's antiMuslim rhetoric (Aziz 2015). So why the fear inducing speeches? He said that these small groups of Muslims have supporters in other countries and those are the groups from whom they need to protect Myanmar. I found this peculiar since the majority of Rohingya do not have homes. Most are now living in camps because radical Buddhists have chased them out of their homes. I do not understand how they would have Internet access or telephones to communicate with other countries or why this alleged Islamic terrorist backing has not arrived after all the detrimental issues the Rohingya have encountered over the last two years. He said that they take business from the Buddhist 
community by creating Muslim storefronts that fund terrorist organizations. I then asked if he could tell me what kind of violent acts the Rohingya are responsible for. All he said to me was that in 1942, 10,000 people were killed in an attack by "Bengalis" (Panna Jota later confirmed that this is most likely fabricated). I address this a bit later in the chapter. Wirathu explained that if Myanmar allows these "Bengalis" to infiltrate the Rakhine state that they will launch jihad against the Buddhist community like they did in Afghanistan, Indonesia and Malaysia. He ended his harangue with, "they are not angels of light" (Wirathu 2015).

The Rohingyas and Buddhist Arakanese continue to disagree about the Muslim community's historical presence in the Rakhine State. The reason why this argument is so important is that when Ne Win seized power over Burma he created the 1982 Burma Citizenship Law, which left the Rohingya community in Arakan stateless. The law states: "Nationals such as the Kachin, Kayah, Karen, Chin, Burman, Mon, Rakhine or Shan and ethnic groups as have settled in any of the territories included within the State as their permanent home from a period anterior to 1185 B.E., 1823 A.D. are Burma citizens” (Poling 2014). The law goes on to name 135 ethnic minorities within Burma with the exclusion of the Rohingya. Because the Rohingya do not have the adequate documentation to prove their Arakanese residence prior to 1823, they were henceforth labeled illegal immigrants. The year 1823 was chosen specifically to drive out anyone whose family migrated during the First Anglo-Burman war (Poling 2014). However, in 1799, a surgeon from the British East India Company, Francis Buchanan, documented that he met a group of Arakan settlers who called themselves "Rooinga or natives of Arakan.” While observing the natives and deciphering the dialects of their language he 
referred to them as, "Mohammedans who were Burma Empire natives that derived from the Hindu Nation” (Buchanan 1799, 219-240). When I told Wirathu about this he said it was fabricated nonsense.

My interview with Wirathu ended abruptly when I began to ask about his upbringing. He was reluctant to engage in talks about where he was raised and among what groups he lived as an adolescent. He offered us desserts and we said goodbye. He continued to provide a warm and at times a silly-faced welcome every time we crossed paths in the next 30 days on the grounds of the monastery. Wirathu always turned on the charm. I watched him pull out of the monastery in luxury vehicles on several occasions; he would be fanned during lunch by one of his many assistants. He does not lead the average monk's life. His following is great and even those who do not follow him respect him enough to not argue against him, as I mentioned during my first meeting with Ma Candasiri in the previous chapter.

\section{U Ashin Candavara}

Wirathu's popularity extends beyond the monks at New Ma So Yein Monastery. As I mentioned earlier, he has photos in his office with the chancellor at Sitagu Sayadaw Buddhist Academy, Ashin Nyanissara. I find this interesting because I have seen video footage of Ashin Nyanissara condemning violence against Muslims in Myanmar at a press conference in Tehran (Fuller 2015). Yet, he and many others supported the Ma Ba Tha laws for the interreligious marriage ban that Wirathu strongly lobbied for.

One of Wirathu's supporters is Ashin Candavara, a teacher at the academy. Candavara is an interesting subject who helped me to develop several theories as to why 
many monks are willing to follow these rhetorically violent agendas despite their inconsistencies with the Buddhist Vinaya: for such monks, they follow Wirathu mostly as a means of survival. Candavara was an amenable subject who would change his demeanor depending on the audience. Another charmer, much like Wirathu, he openly told me he desired fame and wealth in order to help Buddhism's burgeoning in Myanmar. I debated with him often about the implications of generalizing about people based on their religious identity, and often feared he was venal because of his connections across town with government representatives and wealthy donors.

Candavara is a supporter of the 969 and idolizes Wirathu. He is a dedicated 969 monk who despises Muslims and promotes hateful propaganda against them. He lives by the words, "Not all Muslims are violent, but all violent people in Myanmar are Muslim. They do not belong here” (Candavara 2015). His views were very strict in terms of nationalism. He claims that Ne Win was great for keeping the nation pure, but his fault was that he was a socialist. I responded, "His fault was that he was responsible for the murders of thousands of minorities.” He agreed, but did not retract his statement. He said Than Shwe was worse. He believes the Muslims have infiltrated their way into the government to eventually turn Myanmar into an Islamic state. He claims that they are the ones who begin the violence between Buddhists and Muslims in order to get media attention and attract ISIS or other terrorist groups to have an excuse to invade. He says that for this reason, education and access to technology is key in Myanmar.

Candavara is from a town called Pakokku, located in the Magway region, the same area where Candasiri is from. This means that, like Candasiri, he endured many struggles as the child of farmers. His parents died when he was young and he still 
remembers the pain he felt when his mother died of dehydration crossing the river carrying the onion harvest. He spoke of his struggles as a young boy with two siblings to survive without parents. He became a novice in order to make sure he ate a warm meal every day and perhaps to get past the pain he felt for his losses. He studied in India for two years to receive his MA degree in Buddhism. He often spoke about his desires to be a rich and powerful man. Candavara visited my hotel room several times to help me with my research. This is something that was investigated by the Special Branch ${ }^{8}$ to ensure that there were no violations occurring during the research. He was terrified. I was appalled and refused to provide any information about my subjects to authorities when it was requested. They then left us alone for the rest of my research in Sagaing. Candavara was so kind to me during my stay in Myanmar and always ensured that I was communicating effectively with the monastic and lay communities, as I do not know the language. He also took me to the hospital when I got sick despite the inconvenience to him because he lived in the next town over from where my hotel was located. He constantly brought me food and treats. One evening as we both caught a ride back from Sitagu on a truck, he rode in the back with me instead of taking the front seat. This was something I had never seen a monk do, especially if the seat in the front next to the driver side is available. Monks always abide by the social hierarchy in seat placements and I was honored that he would do such a thing for me.

\footnotetext{
${ }^{8}$ Myanmar's police department has a Special Intelligence Department that investigates monastic affairs and monitors locals (monastic and lay) interactions with foreigners.
} 
Candavara treated the nuns and laywomen much differently than he did me. He was dismissive around the nuns. With me, he exhibited vulnerability and was even submissive when I did not want to follow his plans. He visited me every day at the nunnery while I was there. Kawanami addresses this type of attitude toward nuns among monks in Myanmar. Monks tend to treat nuns in their family or circle of friends with respect, but for the most part treat all others rather derogatorily to go along with Myanmar's prevailing social perception of nuns as mendicants unworthy of donations (Kawanami 2013, 129). Prior to my visit, Candavara had never visited a nunnery. At times I would not pick up the phone because I was doing my research and he would show up unannounced. I thanked him for his offers for excursions outside the nunnery but sent him away because I was in the middle of work with the child nuns. I declined to go to a pagoda with him on a day he showed up with a driver he had paid to take us on an excursion. He had never asked me if I was available that afternoon so I found it very easy to say no because I was already committed to spending the day with the children. The nuns at Thila Nyunt could not believe I sent him away and praised me for being so "brave." I was appalled that someone would expect me to cancel all my plans to go on an excursion in the middle of my work. He later told me that he has never met a woman who is so independent. He called my behavior "like a man."

Candavara also invited me to lecture on women and religion and religious plurality at Sitagu Buddhist Academy. I am grateful to him for this because it gave me the opportunity to reach out to 80 monks and nuns in Sagaing. This ended up growing my network to 200 monks and nuns from Myanmar, Sri Lanka and India, most of whom openly hate Muslims. I have remained in contact with most of them through email and 
social media and was able to interview several of them during my stay. This lecture also inspired many monks and nuns to reach out to me in reference to egalitarian concepts of Buddhist practice. We now share views on feminism and occasionally interpret suttas. I feel that the nuns are more inspired to be veracious about their feelings toward their lack of ordination rights. However, most of my new contacts are encouraged to hate Muslims and exhibit fear of all things Islam. I have also been able to know the reasons that have led these mendicants to this life. Among the 200 new contacts I have made, a great majority joined the order for means of survival, as decided by their parents when they were young children.

One monk in particular confessed his undying love for one of his donors and he confided in me that he had had sex with a woman when he was a novice. When I asked him if he did not see a major contradiction of Buddhist values and vows here as he had not been celibate and preached hatred toward Islam, he first responded that he was ordained after his sexual encounter and did not do it again. As for his hatred, he, too, like Wirathu, justified his speech by claiming the need to protect Buddhism. I will not disclose the location of this monk as I promised confidentiality. However, I am sure that none of the nuns I asked had ever had welcomed sexual encounters during their lives as monastics. One nun hinted at a "terrible violent and disturbing past” that would not let her sleep at night, which occurred prior to her becoming a nun. She was from a rural town in Myanmar where many ethnic minorities were killed during the junta rule.

\section{Conclusion}


To ordain a group of monks solely for political power is not permissible in the Buddhist Vinaya. Yet, it is important to acknowledge that there has been a shift to socially and politically engaged Buddhism. This shift has been led by politically active and pacifistic protests that have a long and respectable history in Buddhism, such as the protests against the Vietnam War. Why should acknowledging the voices of female monastics not be a part of socially responsible Buddhism? To inflict or intend violence upon anyone is not professed in the Vinaya. The rule about a human being within the Vinaya states, Whatever Bhikkhu should intentionally deprive a human being of life or seek a [life-] taking weapon for him, or should utter praise of death, or should urge him toward death saying, 'Good man, what use to you is this miserable life? Death is better for you than life,' having such thoughts in mind and such intentions in mind, in many ways should utter praise of death; he too becomes defeated, not in communion (Pruitt and Norman 2001, 9).

This is found in the four matters entailing defeat in the Pātimokkha. The rhetorical violence against the Rohingya in Myanmar’s Buddhist society is not congruent with the monastic code presented in the Vinaya. If Theravāda Buddhism adheres to this source for the subordination and oppression of women and minorities because it is law, then all other laws ought to be equally valued. Clearly they are not with regard to the Rohingya.

The 969 monks were charming and gregarious. They also hold a prestigious standing with the community despite how many in the community disagree with their hate preaching. I also noticed monks like Wirathu and Candavara were more likely to be profligate, while the nuns (and monks like Panna Jota) were simple and less extravagant. I witnessed Candavara chastise several nuns during our field trips. This was partially why I began to separate the time-sharing with the monks and nuns. The nuns were more likely to voice opinions and answer questions truthfully about what sites we should visit when 
monks were not present. The monks were also much more sincere and noble when the nuns were not around. It seemed like they were role-playing societal expectations when the two groups of monastics were in public spaces versus private spaces. However, the truths I uncovered about hidden secrets and desires brings up questions about how many monastics have these feelings and secrets while playing the roles the group in power asks them to play for means of survival in a seemingly prejudiced and misogynist society.

With Buddhism serving as the central marker of what it is to be ethnically Burmese among the nationalists and monastics, we must acknowledge its fundamental influence in society's treatment and views of women in Myanmar. As I have discussed, Buddhism has served as an authorizing discourse contributing to the legitimization of social hierarchies between the sexes. It seems that the assertion of male superiority on a religious level has trickled down to political institutions and government rulings, granting legal authority to Buddhist monks’ misogynist statements. My findings suggest that Buddhist nationalists see the dreaded infiltration of the Muslim other primarily in terms of the threat they pose to Burmese Buddhist women, who are understood to need protection to prevent the disintegration of Burmese culture by being available to foreign men. Further, women are instrumentalized, being used to piece the culture back together by guarding and circumscribing their capabilities. However, cause and effect are less clear than this. From another perspective one could say that Burmese Buddhism became distorted in the first place was that it was influenced by the cultural context, which then used those religious distortions to justify the cultural context. Religion as a social institution reflects culture. 
At times, monks of the 969 would praise women as mothers. In other instances, they labeled women undisciplined temptresses. Although women are regarded as both, their roles as mothers relate to their families and communities, and as such, they are revered as merit-making entities. That is, as long as they guard their virtue (sila), wellcontrolled women remain a national asset. This is how the discourse of motherhood connects to saya-leis. If they cannot fulfill the roles expected by society as mothers, women often choose to become saya-leis, which still allows them to lead meritorious lives for the community and thus provide a service to powerful men. While piety is a factor in women's choices to become saya-leis, many also choose it to avoid being subject to prostitution and human trafficking, as many of them come from unstable situations. I witnessed this while working with Burmese refugees in Sankhlaburi, Thailand.

The 969 Movement likes the limelight, the luxury, and the mantle of righteousness that have come from its campaign against the Rohingya. The government backs the 969, which serves to distract people from the lack of democracy, education, and development. The masses have never had democracy, nor have they had any experience with minority rights. They are also anxious about their identity in a fast changing world where they feel backward, and so they cling to traditional religious identity. The monks of the 969 Movement use their agenda as their own strategy for dealing with the contemporary world. 


\section{CHAPTER 3}

The Muslim Other in Burmese History and Buddhist Discourse

In pre-colonial Myanmar, the Buddhist sangha was a parallel institution to the state; royal patronage of the sangha was the chief means of legitimizing a king's rule. In periods of political turmoil, however, the sangha was rarely, if ever, seen by the populace as party to the excesses of overreaching monarchs. Although Buddhism has always leaned toward being the sole religion of Myanmar, there were periods of peace within a religiously plural society. With colonialism came waves of migrations, which contributed to the feelings of invasion and fears that nationalist Buddhists still live with in the present. In turn, these feelings result in the oppression of anyone who is not Buddhist, which seems to be one in the same as being Burmese and has been associated as so for the majority since the beginning of Burmese history.

In this chapter, I briefly describe some fundamental aspects of Burmese monarchs and their relationships to religion in pre-colonial Myanmar. I address Buddhist texts that were used to justify kingly actions. I also focus on the impact Buddhism had on Myanmar economically, environmentally, ethnically and ethically. Then I focus on the events that led to this angry Buddhist nationalism brought on by British colonization. Here, I address the insecurities embedded into the Buddhist psyche by the waves of foreign migrants, specifically Indians and Muslims, brought in under British rule.

Following the British era, I provide a historical overview of the evidence for the Rohingya’s legitimacy as Myanmar citizens, evidence ignored or negated by the Myanmar government and nationalist Buddhists alike. At the end of the chapter I discuss four fundamental criteria for genocide and how they fit into the treatment of the 
Rohingya by Myanmar’s government and nationalist Buddhists. It is important to understand that Myanmar’s Buddhist nationalism and marginalization of the Rohingya has always been a part and parcel of the Burmese ruling parties. In this chapter I discuss the narrative sources of Buddhist nationalism and anti-foreign racism that underlay the rhetoric used by Burmese Buddhist nationalists to justify injustices toward “others” today.

\section{History of Pre-Colonial Myanmar}

According to the chronicles of Burmese kings documented in the Sāsana Vamsa, ${ }^{9}$ Myanmar’s monarchy traces back to King Abhiraja. Century? Abhiraja was the prince of the future Buddha's Sakya clan. Long before the Buddha's sermon in Sarnath, the king of Panchala asked for the hand of the King of Kosala’s daughter in marriage. The king of Kosala believed his lineage was much too noble for Panchala and war ensued. Panchala won the war and the Kosala family was forced to head east. After leaving India, Abhiraja, a prince of the Kosala clan, settled in the Irrawaddy River valley. It was then said that Abhiraja’s eldest son founded the kingdom of Arakan (modern day Rakhine) when he traveled farther south in India (Myint-U 2006, 43). These Burmese chronicles also state that the Buddha miraculously flew over Myanmar (as he did in Sri Lanka) and claimed that Buddhism would eventually rule over ancient Pegu (lower Burma), located on the Gulf of Martaban (Gier 2014, 69). However, there is no mention of this incident within

\footnotetext{
${ }^{9}$ The Sāsana Vamsa is a chronicle written in Pāli by a bhikkhu, Pañnaā-saāmi, for the Fifth Buddhist Council held in Mandalay in 1867. As the Sāsana Vamsa is a recent compilation, many events mentioned therein may be doubted. However, as it draws both on written records, some of which are no longer available, and on the oral tradition of Myanmar, information can be included in this account with the understanding that it is open to verification (Bischoff 1995).
} 
the tipitaka. ${ }^{10}$ As a matter of fact, none of Burmese Buddhist history is considered canonical (Leider 2008).

The Sāsana Vamsa is based on the Mahāvamsa and other well-known Sinhala works. It reflects many non-canonical tales of Burmese Buddhist history not mentioned anywhere prior to the King chronicles in 1770 , when promotion of orthodox Therāvada Buddhism led to the writing of new histories of Buddhism in Burma. Later in this chapter I will introduce the king responsible for that, Bodawphaya. British scholars asserted that the antiquity of the chronicle tradition and possibility of civilization in Burma prior to 500 CE was not viable (Myint-U 2006, 44). Still, recent research suggests that civilizations along the Irrawaddy River are very old and could possibly trace back to 2,500 years ago (ibid., 45). Myint-U goes on to say, “Abhiraja, if he really existed, was not the only ancient traveler to Burma” (ibid., 46). The Sāsana Vamsa also includes a story of two Burmese merchants, Tapussa and Ballika, who met the Buddha and received eight hairs from his head. These hairs became relics that now reside in the Shwedagon Pagoda buried under sixty tons of gold (Gier 2014, 67).

Bhikkhu Silacara was a man by the name of J.F. McKechnie who was admitted into the sangha in Rangoon by Thera U Kumara in the late 1940’s. I found his work particularly interesting because his articulation of the life of the Buddha adheres to the

\footnotetext{
${ }^{10}$ The Tipitaka (Pāli canon) assumed its final form in $250 \mathrm{BCE}$ at the Third Buddhist Council, but was not written until the $1^{\text {st }}$ century BCE. Buddhist scholar-monks in Sri Lanka and southern India began to compile the texts and commentaries along with Pāli grammars, scholarly articles and historical chronicles. The texts were written in Sinhala, the language of Sri Lanka, despite Pāli being the lingua franca of Theravada. It wasn't until the $5^{\text {th }}$ century CE that the Indian monk Buddhaghosa translated the tipitaka so that other Buddhists had access to the texts.
} 
Sāsana Vamsa in terms of strong Burmese and Singhalese roots embedded into the Buddha's life. The work was published in Sri Lanka. Silacara's version of the story of the two Burmese merchants, Tapussa and Ballika, refers to them as, "the first men in the world to call themselves followers of the Buddha” in the city of Uruvela (Bhikkhu Silacara 1953). According to Silacara, when the Buddha made the first five men arahants, and recruited the first 60 disciples, he sent them out independent of one another in all the cardinal directions. The passage states,

And these sixty Arahants did as their Master told them to do, and carried a knowledge of His Teaching and Discipline, North and South, and East and West. They were the first men in the world who went abroad into foreign countries for the sole purpose of spreading a knowledge of the religious truth they believed in. They were, in fact, the first duly appointed missionaries of a religion the world has seen (Bhikkhu Silacara 1953).

Among these disciples was one who sought to convert the most stubborn and "wild" people. The Buddha asked the bhikkhu what he would do if the wild ones tried to kill him for spreading Buddhism, to which the bhikkhu responded,

I shall say to myself: "These people are doing me a great favor, for this body of mine is an evil thing of which I shall be glad to be rid; and these good people are going to rid me of it." Then the Buddha said: "Go O Bhikkhu, and make known my Teaching among these people. Bhikkhus like you are the proper kind of Bhikkhus to publish abroad my Doctrine among all the peoples and nations of the world” (Bhikkhu Silacara 1953).

After the dialogue about possible outcomes of his attempt to convert "the wild," the Buddha exhibits pride in the bhikkhu's decision to risk his life and be grateful to die in the name of the Buddha's doctrine. This narrative supports nationalist notions of absolutism and the future of Buddhism as outranking an individual life, though it is in this account one's own life that is voluntarily risked. Additionally, Buddha expresses that 
the disciple is the "proper” kind of bhikkhu for doing so. This book was written for a young audience in order to provide an in depth, but less complex, rendition of the Sanskrit Buddha Carita, a first-century CE text that is the earliest telling of the life of the Buddha.

Moving forward with the rise of Buddhism in Myanmar, mythology became history around the fourth century CE when the kings of Prome (who claim to be descendants of Abhiraja) inaugurated Pagan (Bagan) kings among statues of Sakka ${ }^{11}$ and Brahmā believed to hold a place for the nobility for the possibility of becoming the future Buddha, Metteyya ${ }^{12}$ through merit earning. They were then given Hindu names like Vikram and Visnu. By the seventh century CE Ari Buddhism ${ }^{13}$ spread from Tibet and North India. Its popularity was not as successful as the Theravāda tradition due to the questionable practice of eating beef and drinking alcohol exhibited by the tantric lamas (Gier 2014, 70). These pluralistic and inclusive practices of Buddhism continued through the $10^{\text {th }}$ century.

In the $10^{\text {th }}$ century, the Ari Buddhist Pagan King Aniruddha ruled. His general was a Muslim named Byatta. Aniruddha was known to perform deity worship despite his formal adoption of the more "orthodox" Theravāda Buddhist practice. Hindu priests were also often invited to perform rituals for the king. Inclusively, Aniruddha allowed a Tamil

\footnotetext{
${ }^{11}$ Sakka is the Pali name used by Buddhists for the Vedic god Indra, who is also known as Shakra in Sanskrit.

${ }^{12}$ Metteyya - In Burma and Sri Lanka, the next coming of the Buddha is generally spoken of as Ari Metteyya, “the Noble Metteyya," and is an important aspect of Buddhist eschatology (Chit Tin 1992).

${ }^{13}$ Ari Buddhism was a Tantric sect that mixed animism, serpent ( $n \bar{a} g a$ ) worship and Hinduism.
} 
merchant to build a Hindu temple named Nanadesi Vinnagar Alvar, which translates to "Visnu temple of those coming from various countries.” Aniruddha's rule was fruitful for Myanmar, whose population reached 2.5 million under his rule (Gier 2014, 71).

During Aniruddha's rule, it was the king's duty to purify the sangha. Meritearning was of utmost importance for these Buddhist kings. Buddhist relics and temple building became a priority for Aniruddha. Present day Bagan still boasts 2,500 of his pagodas and stupas. When Aniruddha was denied the correct version of the Pali canon he attacked northern Burma to obtain it and later attacked northern Burma for "the Buddha's holy tooth.” He also destroyed the ancient capital city of Srī Ksetra to obtain other Buddhist relics. Ironically, the king who was in charge of purifying the sangha, and who was considered a nat, ${ }^{14}$ waged war against his fellow Buddhists (Gier 2014, 72). Additionally, his temple building reduced the amount of land available for cultivation from 600,000 acres to 250,000 acres and contributed greatly to the decline of his Burmese dynasty (see figure 3) (Gier 2014, 71).

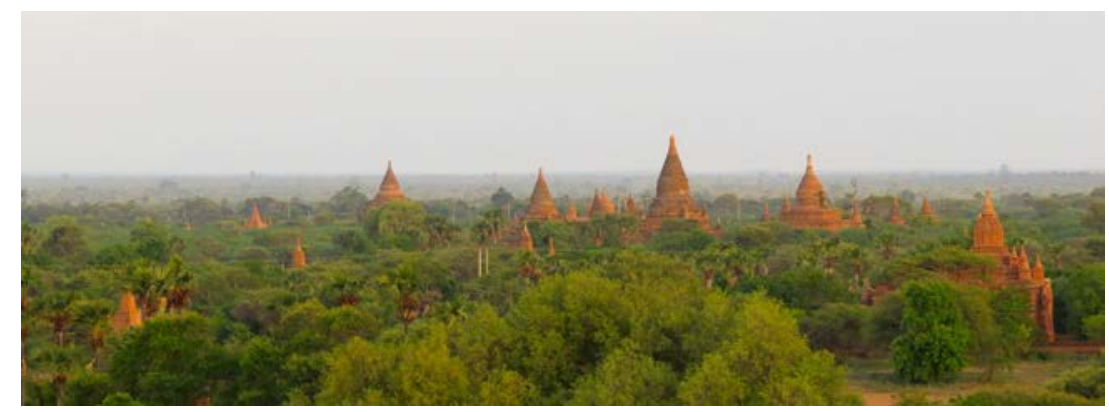

Figure 3. Bagan 2015

In modern day Myanmar, merit making continues to be prioritized over economic and environmental sustainability. I witnessed this during my fieldwork when I was

\footnotetext{
${ }^{14}$ Nats are humans deemed spirits of worship after death due to their high merit status in life (Braun 2001).
} 
fortunate enough to meet a politician and owner of the Jade Pagoda in Amarapura / Mandalay, U Soe Naing. He boasted about the millions of dollars that he spent building the jade structure. Ironically, driving up to the Jade Pagoda, I watched children covered in mud peddling for scraps in 100-degree Fahrenheit temperatures. When I asked what kind of jobs this provided for the locals, he informed me that he was also running for political office and once elected he would ensure the people find work in the massive land he cleared to build a shopping plaza. To solidify his character he informed me that he once purposely regurgitated his food on the side of the road to feed a stray dog. Many who were a part of the conversation attested to this, and most of the people I encountered at the Pagoda were proud of his accomplishments, regarding him as extremely benevolent and a true humanitarian. However, Panna Jota was the only one who sympathized with me as we saw the adverse effects of these actions being less likely to benefit the people and more likely to build U Soe Naing's own personal merit as had been the case for Aniruddha and the ancient temples of Bagan.

For centuries after, the kingdom continued to be predominately Theravādin, but was tolerant of Hindus and Muslims. This is not to say that there was never conflict, but society was generally harmonious. There was much assimilation and syncretism, which led to pre-modern social solidarity during the rule of the Pagan King Kalancacsā 10841112 CE (Gier 2014, 72). On December 17, 1297, the Chinese Emperor of the Mongol army, Kublai Khan, invaded the Pagan kingdom bringing it to its end after 250 years of Buddhist rule. In the $14^{\text {th }}$ century, Turkish and Afghan forces from East Bengal invaded and King Naramithia created a Buddhist-Islamic dynasty at Mrauk-U after being exiled from west Arakan. Arakanese, Bengalis, Afghans, Dutch, Portuguese, Persians and 
Japanese mixed with the Arakanese and Burmese population, who previously occupied the land. From the $16^{\text {th }}$ century forward, Arakanese kings used Islamic titles although the majority of the court was Buddhist (Gier 2014, 73). This enriched the religious syncretism of the state; for example, Arakanese marriage customs reflect strong Muslim influence (Gier 2014, 73).

King Bayinnaung (1516-1581) conquered the Bengali Sultanate, gaining control of the Gulf of Martaban and Pegu; he also defeated Burma’s archrival, Siam. He flourished, becoming the most powerful king in Southeast Asia by 1554. He was revered as a "Dharma-wheel-turning king" (Palī, cakkavatti) (Myint-U 2006, 63). This title was the greatest honor a king could attain, as it indicated both worldly and otherworldly sovereignty. The Cakkavatti-Sihanada Sutta (The Wheel-Turning Monarch) calls him an exemplary figure in terms of his establishment of a Buddhist empire and his attainment of nibbana. The sutta addresses King Dalhanemi’s coping with the loss of the sacred wheel treasure after thousands of years in the kingdom. This meant death was approaching for the ruling wheel-turning monarch. As tradition required, the king shaved his head and put on robes to lead a life as a homeless wanderer. However, a "certain man” appeared before the king and told him what was expected of a wheel-turning monarch in order for the wheel to reappear with a thousand spokes, complete with rim, hub and accessories. He continues:

You must depend on the Dhamma, honoring it, revering it, cherishing it, doing homage to it, and venerating it, having the Dhamma as your badge and banner, acknowledging the Dhamma as your master you should establish righteous guard, ward and protection of your household, your troops, your khattiyas and vassals, for Brahmins and householders, town and country folk, ascetics, and Brahmins for beasts and birds. Let no crime 
prevail in your kingdom and to those who are in need give wealth (DN: 26 Cakkavatti-Sihanada Sutta III.59-63).

When the king completed his wheel- turning duties the sacred wheel appeared to him. The wheel then turned in every direction and the king and his armies followed. Wherever the wheel stopped, the king conquered (Bhikkhu Bodhi 2005, 139-141). This sutta puts the achievements of Bayinnaung into perspective and justifies the title given to him by the Buddhist Burmese population he ruled over. Myint-U adds, "For today’s generals and others of a more belligerent nationalist persuasion, Bayinnaung represents a glorious past, something to be missed, and a sign, however, distant, that Burma was not always so lowly in the eyes of the world” (Myint-U 2006, 63). Bayinnaung symbolizes the infiltration of Burmese into Siamese and Bengali land, interpreted by militant Burmese to mean that iron fists produce greatness.

The next noteworthy king, known as “The Grandfather King,” is Bodawphaya (1782-1819). Like all but the last Burmese monarch, Bodawphaya took many wives, 207 queens and concubines to be exact (Myint-U 2006, 105). His proto-nationalist version of Buddhism is the one that resonates most with the Buddhism practiced by Wirathu and the 969 supporters in Myanmar today. Bodawphaya’s actions were performed in order to carry out his dharma as a just Buddhist ruler. He was a stay-at- home king who enjoyed debating with scholars and monks about history and religion, but nonetheless he ensured that his military raged war on Arakan and Siam (Myint-U 2006, 105). Wirathu's ideals seem to have the same foundations, in terms of seeking Burmese Buddhist purity. Although Bodawphaya was a staunch supporter of Buddhism and set out to make 
Myanmar completely Buddhist, the sangha rejected him in the honorary role as a potential Metteyya.

In 1785, King Bodawphaya argued that his intent for conquering the Arakanese kingdom of Mrauk-U was for the sole purpose of purifying the sāsana, the Buddhist religion. However, skeptics attribute it to the facility of conquering a weak and split state (Leider 2008, 413). The accessibility to Bengal's maritime trade was also enticing for a king on the prowl. This argument for waging war - purifying the sāsana - supports the justifications provided by present day anti-Muslim Buddhist religious leaders like Wirathu. Walton writes,

According to U Wirathu, the movement 'is about protecting the religion, but also protecting the nation, the race, the country. It's not just about protecting the sāsana, but protecting the country.' This rhetoric reinforces the notion that the well-being of the religious and political communities are inextricably intertwined. The argument for the defense of the sāsana is compelling and difficult to refute since no Buddhist can afford to be accused of failing to defend the religion (Walton and Hayward 2014, 22).

Historical records like Bodawphaya’s legacy add to this paradox of Burmese authenticity because the "split” kingdom consisted of Muslims, Buddhists and syncretistic Buddhists, hence the dire need for “purification.” However, according to Walton, these allegations of impurities were merely referring to co-religionist practices and the close ties the Arakanese kept with Islamic sultanates to the west (Walton and Hayward 2014, 21). Many Muslims came from India during this time. Amarapura had 40 mosques and about 9,000 Muslims. A British visitor during the reign of Bodawpaya recorded, “Their women of all ranks go unveiled and clothe as scantily as the rest of the countrywomen; they marry for love and women even pray in the same mosques as men” (Myint-U 2006, 126). Muslims were the mayors and governors of Bagan and Ava at the 
time, attesting to the inclusive nature of the kingdom (Gier 2014, 74). However, this did not last long, as the British brought in laborers and administrators from India during their colonization.

As I have presented, in pre-modern Burma the monarchy and Buddhist sangha were always in a close-knit relationship, though it seems in conflict over power. The control of the sangha benefitted the state and, in turn, the purity of the state (the absence of competing religions or religious influence) imposed on the sangha was to the advantage of the Buddhist leaders (Taylor 2009, 52). Kings were able to maintain control of the country's wealth and they ensured that Buddhism and its minimalistic economic views were maintained as the national religion. It was not until the British invaded that there was a separation of church and state. Burmese Buddhists who acted in ways similar to how we see Buddhist nationalists do today generally perceived this as a weakening of culture. The British did not allow the colonial era leaders to appoint their replacements in the sangha, as had been traditionally done in past Burmese empires.

\section{From Myanmar to Burma}

The Burmese began to battle for control of their own land in 1824 when the British ignited the First Anglo-Burmese War. The British ruled over Myanmar, renaming it Burma, a name it kept until its independence in 1948. Colonization flooded the country with Christian Britons and waves of Indian immigration brought a variety of Muslim ethnic groups to reside in the border cities throughout the country. This history contributes to both the fear-induced speeches that are still used by Wirathu, and nationalist discourses throughout the country at present. Because the country was under 
British rule for as long as it was, the fear of national/cultural/religious disintegration becomes understandable. Here, religion is considered identical to ethnicity, which in turn paves the way for Buddhist nationalism to become hegemonic in Burmese politics (Chatterjee 1993, 74).

In the 1920's, the British brought 500,000 Indians to Burma. The population in Rangoon reached 55\% Indian (Gier 2014, 77). At this time, a nationalist peasant group formed under the name Wunthanu Athin. Wunthanu derives from Pāli and means “supporting [one’s] own race” (Taylor 2009, 194). A nationalist monk movement, the General Council of Sangha Sammegi (GCSS), led by U Ottama, trained them. Ottama was an educated and well-traveled monk who spent the first 20 years of the $20^{\text {th }}$ century abroad. When he came back to Burma, he began to encourage the peasantry to rise up against the oppressive colonial rule exploiting them with obscene impositions of taxes and over-cultivation. He argued that it was time for the Buddhist community, monastics and lay alike, to involve itself in secular affairs, as the wellbeing of the religion is dependent on the wellbeing of its people. What was once a symbiotic relationship between the state and the religion had become a symbiotic relationship between the people and the religion, with the state as the cause of distress to both (Taylor 2009, 183). Although elder monks were reluctant to join Ottama at first, they not only backed him but joined forces with other nationalist movements across the country after his imprisonment by the British (which ultimately led to his death as result of a hunger strike). The 12,000 branches of General Council of Burmese Associations (GCBA) joined forces with Ottama's GCSS and even the most conservative Buddhists (who disapproved of monk involvement in politics) began to rally against the British rule. However, many monks 
suffered brutal beatings and death through these uprisings (Taylor 2009, 184). The situation became even more complex and dangerous when the elite Burmese did not join them because they were direct benefactors of colonialism (Taylor 2009, 185). The antiBritish rule riots of the 1930's led by GCBA also targeted Muslims, with monks as leaders. According to Taylor (2009), in 1938 monks began rioting over an anti-Buddhist publication from 1931. The government concluded that the riots were caused by the discontent of the peasants over land tenure, anti-Indian feelings, the marriages of Buddhist women and Muslim men, and the Ba Maw ${ }^{15}$ government (Taylor 2009, 201). In the 1930's General Aung San began activist movements to overthrow the British. He founded the Burmese Communist Party. Although their ideologies differed, he had the support of $\mathrm{U}$ Nu who was interested more in peace building than war. Aung San was not enticed by Gandhi’s non-violent political movements and often critiqued them. Ironically, he is the father of the non-violent icon Aung San Suu Kyi, well known for her pacifist tactics against the junta’s oppression. Aung San wanted a communist state and defeated the British in April 1947 when the Burmese people voted for Aung San’s Anti-Fascist League. However, his victory was short-lived, as he was shot dead in July that same year (Gier 2014, 80).

Myanmar declared its independence from the British on January 4, 1948. U Nu was then declared the first prime minister of Burma and as a devout Buddhist declared

\footnotetext{
${ }^{15}$ Dr. Ba Maw was a Burmese politician educated at Cambridge and earned his doctorate at University of Bordeaux. He defended the peasant rebellions, but remained within the law and was often criticized by nationalists for keeping his anti-separatist views in hopes of democracy (Taylor 2009, 172). The nationalist rebellions he fell victim to are much like Daw Aung San Suu Kyi’s defamations by the 969 Movement.
} 
Buddhism the national religion — contrary to the wishes of the late Aung San, who desired a secular state. However, it is important to note that $\mathrm{U}$ Nu created a law for religious freedom that allowed Muslims and Christians to teach the Bible and Qur'an in schools as well, since Buddhism was a required subject (Gier 2014, 84). U Nu is the only Myanmar head of state to grant the Rohingya ethnic minority status (Jilani 1999). Still, civil war among the 135 ethnic minorities plagued Burma immediately after its independence from the British.

In 1948, the Muslims of Arakan voiced their political desires and the Burmese government resisted. The Muslims then declared jihad and took over the Mayu region (Gier 2014, 81). This modern Islamic revolution continues to justify the fear embedded in Myanmar's nationalist Buddhist narratives. However, simultaneous to these events Buddhist monks were in dire need of "purification" in Burma as they were revolting against Muslim minorities throughout the nation outside of the Mayu region, setting mosques on fire and protesting U Nu's religious pluralism (Gier 2014, 84). Aung Thwin (2009) states, "Monks during the so-called "democracy period" were involved in all sorts of serious crimes including forgery, sedition, opium smuggling, armed robbery, destruction of private property, rape, assault with deadly weapons and murder.”

In 1958, U Nu experienced a schism in his regime from which the current state of Myanmar is still recovering. His release of political prisoners and legalization of the Communist Party was ultimately detrimental to the Anti-Fascist Freedom League. In 1962, Ne Win executed a coup d'état and claimed power, renaming the country the Union of Myanmar. This wreaked havoc across the nation among monastics, military and ethnic minorities. Many Burmese scholars and well-educated nationals left the country because 
of this. He began pogroms against Indian and Muslim minorities by nationalizing their businesses and sending them off with one-way tickets "home” (Gier 2014, 85).

The extent of Ne Win's oppression of the Rohingya goes much further. When he led the army to seize power from $\mathrm{U} \mathrm{Nu}$, he set up intelligence operators to spy on the citizens. He decided that Myanmar should be sealed off from all kinds of foreign influence. Despite being notorious for his addiction to gambling, he banned gambling for the Burmese; he cracked down on the press and imposed censorship upon newspapers, radio, books and films (Inside Burma 1997). This sort of action is common among dictators to prevent the exposure of contradicting ideals to its oppressed. All sources that do not accord to the ruler's implementations are banned. This element is crucial to this study because Ne Win's ending the country’s access to literature and global modernity caused the population to lack the resources to counter Ne Win's narratives of the history of Myanmar and his portrayal of the roles played by Muslims and other ethnic minorities in the country, specifically, any and all evidence of Rohingya's preexistence in Burma before the colonial period. Ne Win’s government restricted religious freedoms for all non-Buddhists. These restrictions applied to construction of religious sites, public worship and places of residence (Inside Burma 1997).

Burmese society had become infused with other Asian cultures during migration waves. Myanmar has not conducted a census since 1983; even that one has questionable legitimacy, having been repeatedly critiqued for its omission of the masses of ethnic minorities in conflicted areas. Many areas are avoided by the census takers due to the risk of violent disorder and because of the high likelihood of government violence against people claiming to be part of persecuted minorities. In March of 2014, Myanmar 
performed a new census with the support of the United Nations Population Fund (UNFPA). The new figures reported 51.4 million people and 135 ethnic communities. The Rohingya are not included in the census, nor is this designation included in the list of ethnic groups. Burmans make up 68\%, Shan 9\%, Karen 7\%, Rakhine 4\%, Mon 2\% and Kachin 1.5\% (Walton and Hayward 2014, 4).

The majority of non-Burman groups live on the outskirts of the country, by the borders of Bangladesh, India, China and Thailand. Theravāda Buddhism predominates among Burmans and many of the ethnic minorities alike. Overall, Theravāda Buddhism is practiced by $89 \%$ of the Burmese population. Christians and Muslims tie at $4 \%$ each and the remaining 3\% includes indigenous animism, Hinduism and Baha'i. Despite the government's promise to allow write-ins during the 2014 census, at the last minute it annulled its promise and banned anyone from writing in "Rohingya" as an ethnicity due to the tensions it caused among Rakhine Buddhists (Walton and Hayward 2014, 5). To reiterate, the fear instilled by the nationalist Buddhists, although the census was executed safely without any riots breaking out, skeptics awaited the inevitable uproar from the 969 and other anti-Muslim groups when the results are publicly distributed throughout $2015^{16}$ and show an increase in the proportion of Muslim citizens (International Crisis Group 2014).

Myanmar has been battling to protect ethnic purity for as long as the Burmese have been documenting and rewriting history. Wirathu and his nationalist following still cling to the ideology that ethnic purity is of central importance, and is threatened by

\footnotetext{
${ }^{16}$ No new information has been published in terms of reactions prior to publishing this thesis.
} 
current events, reports of rapes and (Nilson 2015). The term democracy is used loosely here, as the regime continued to abide by most of the nationalist implementations set by Ne Win. Additionally, the constitution limits the number of parliament seats that can be voted on and bans many persons from holding office. For the 969 monks, Buddhism is an ethnicity that holds more value than the central pacifist Buddhist belief in non-violence.

In August 2012, President Thein Sein suggested that the United Nations High Commission for Refugees remove the 800,000 displaced Rohingyas from the country. One month later, Wirathu led thousands of monks to march in support of this suggestion (Walton and Hayward 2014, 13). Since Thein Sein stepped into office he has released many political prisoners, relaxed press restrictions, and allowed peaceful demonstrations and union formation. He has also agreed to propose a nationwide ceasefire, but backed out at the last minute. Moreover, political activists have been imprisoned. The elite who have strong connections to the military control foreign investment, and most of the rural ethnic minorities are still impoverished (Walton and Hayward 2014, 3).

The Rohingya remain the most persecuted minority on the planet. Thein Sein also has made an official statement claiming that, "969," is a symbol of peace and that Wirathu is a "son of the Buddha” (Marshall 2013). The fear-induced hate speech Thein Sein encourages from Wirathu creates a nation dependent on the nationalist regime for comfort and protection. However, this is paradoxical because Wirathu also mentions that while the media covers the "Buddhist terrorism upon the Rohingya," they ignore that the Rakhine state is also home to many impoverished Buddhists who feel like the government does nothing for their wellbeing or safety (Walton and Hayward 2014, 3). 


\section{History of the Rohingya in Myanmar}

The Arakan (Rakhine) region has a long coastal region, which merges with the Bay of

Bengal and the Indian Ocean. Zarni and Cowley $(2014,693)$ explain,

Because of this geography, the region as a whole has a unique history visà-vis the landlocked central political systems of ancient Burmese Buddhists, and has a history of interdependence with Bengal, which was a natural source of cultural, economic, and labor exchange. Thus, to claim that Rakhine was only home only to Buddhist populations in centuries past is ahistorical.

These kinds of blended border ethnicities are common in Southeast Asia. We also see the partition of the Shan state, which includes people in adjoining territory in China and Thailand who share common religions and languages (Aung Gyi 1961). According to Jilani (1999), Islam reached Arakan before 788 CE. Records show that the Rohingya language was used by the predominately Muslim Rohingya and Arakanese Buddhists in Arakan during this time. The Arakan state is adjacent to the border of Bangladesh along the Naf River, known in that country as the Mayu Region. Additionally, Muslims in Arakan have been mentioned as co-inhabitants of the Mrauk-U dynasty (1430-1785) with the Buddhist Arakanese. However, the British colonization of India and Burma, especially during the First Anglo-Burmese War in 1824-26, encouraged large-scale immigrations. This caused much tension between the Buddhists of Central Arakan and the migrating Muslims from Chittagong coming into the northwest. As Wirathu pointed out when he claimed my Buchannan (1799) reference was nonsense (see Chapter 2), arguments remain strong among Burmese democrats and nationalists that these historical 
claims are false and that the Rohingyas are in fact descendants of immigrant Chittagonians that came over from East Bengal during British rule (Nemoto n.d., 3).

One source opposing the legitimacy of the Rohingya is Criticizing the Falsification of the History Written by Bengali Immigrants who were the Descendants of the Chittagonians using the name "Rohingya" Under a False Name of Human Rights (War 2003). The book's main counterargument focuses on the politically driven discourse "misrepresented" as a history of Arakan. War claims that it is just a ploy to paint a picture that Arakan was predominately Muslim before it was Buddhist, a claim with which most nationalist Buddhists in Myanmar disagree. War also claims that there is no documented proof of the declaration that shipwrecks brought Arabs to Burma as Jilani and other Rohingya-supporting authors state in their works. War also claims that the Muslims of the Mrauk-U dynasty were in fact minorities. However, even if they were always minorities, how would that undermine the legitimacy of the existence of the Rohingya in Myanmar? Most were Bengali captives and mercenaries from Persia and Golkonda (Nemoto n.d., 8-10).

Yegar (2002), who seems impartial in the debate, argues that the Rohingya migration to Arakan/Rakhine occurred in three different stages. He describes the MraukU dynasty as the first setting for Islam's appearance in Arakan. He attributes the immigration wave from the Mughal Kingdom in India, specifically Bengal, to this Muslim infusion in the region. The second and third stages are attributed to the immigration waves of the Chittagong in the $19^{\text {th }}$ century during the British rule that led to the marriages of Mrauk-U dynasty Muslims and Chittagong Muslims that eventually led to what we now call the Rohingyas. Although he begins his argument with the Mrauk-U 
dynasty wave of immigration, he does not rule out the possibility of Islam reaching Arakan in the $9^{\text {th }}$ century as suggested by other scholars. He states that the probability of seafarers from Bengal settling in the area during the $9^{\text {th }}$ century is not far-fetched, however, he does not attribute the name Rohingya to them.

Yegar (2002) states that in the late 1660’s a wave of Muslims came into Arakan following the Mogul Prince Shah Shuja’s arrival. The Arakanese king killed him and his children and his soldiers were put in a special mercenary unit for Arakan called Kaman. By 1684, those Kaman unit mercenaries formed a rebellion alongside Bengali prisoners and Afghan mercenaries. For twenty years, the Muslims backed by Afghan mercenaries from Northern India ruled over the region until King Sandawizay conquered them in 1710. He exiled these Muslims to Ramree Island and their descendants are today referred to as Kaman Muslims who reside in Arakan (Yegar 2002, 24). In the present day, there have been incidents of Kaman Muslims being on the receiving end of Buddhist violence during 969-incited riots, although the Burmese Citizenship Law recognizes them as a Burmese ethnic minority. This will be discussed in the next section when I begin to analyze the trickle down effects of these historical accounts on present day Buddhist / Rohingya violence and claims of legitimacy in Myanmar.

During the Japanese occupation of the 1940’s, the British used “Chittagonian and Mahomedan” Muslim forces for counterattacks against the Buddhist Arakans, whom the Japanese had armed. By 1948, hatred against Muslims was already embedded in the fabric of the Buddhist Arakan community, despite Burma's independence from the British, who were blamed for the Muslim problem. There are records of peace-building tactics in the works during the 1950's between the Muslims and Buddhists, but that ended 
abruptly as Ne Win initiated a coup d'état in 1962. By 1974, the Ne Win government denied citizenship and acceptance as a Burmese minority to the Rohingyas in the Arakan state, despite U Nu's prior recognition of them as an ethnic Burmese minority (Nemoto n.d., 3-4).

In 1978, Burma issued a census set out to alienate the Rohingya population in Arakan. They called it Operation Nagamin. Two hundred thousand Rohingyas living in Arakan fled to Bangladesh due to what the Head of the UNHCR Sub-office in Bangladesh called

the heavy-handed methods of the police and soldiers carrying out these operations, and their exploitation of the opportunities for extortion inherent in a situation where some people lacked documentary proof of their right to reside in Burma, accompanied by an upsurge in violent clashes between the two communities, [which] created a climate of fear. News or rumors of beatings, abductions, and killing of Muslim men, and of the rape of Muslim women, spread from village to village, and many Muslim families were spurred into flight (Lindquist 1979).

The Burmese government has blocked humanitarian aide and controlled food rations to the displaced and stateless Rohingya since then. This led to the death of 12,000 Rohingyas between Bangladesh and Myanmar in 1978. Bangladesh returned 187,000 Rohingyas to Myanmar after the exodus. Zarni and Cowley $(2014,708)$ note, "It further fed into the popular perception in Myanmar of illegal infiltration by Bengalis, as the population of Myanmar was led to believe that it was not Rohingya that returned to Myanmar, but illegal Bengali immigrants who arrived as evidenced by the discrepancy in figures.”

Anti-Indian racism exacerbates the plight of the Rohingya. From 1824 to 1935, the resentment the Burmese felt as they watched their lands and resources exploited and 
taken from them is memorialized in the fabric of the nationalist's view of society. Additionally, Ne Win's power structure subjugated this fear by making it clear in 1982 that kalaars cannot be entrusted with any positions of importance, specifically in bureaucracy and armed forces (Zarni and Cowley 2014, 697). He played on the people's fears by reminding them of their inability to shape their destiny during colonization. Wirathu's 969 Movement continues to encourage these fears. When a gang of armed Buddhists burned down 1000 buildings and killed over 100 Muslims, including children in 2013, Wirathu was quoted as having responded, "If we are weak our land will become Muslim” (Zarni 2013).

It seems that Myanmar's nationalists are treating the Rohingyas just the same as the military regime that oppressed not just the Rohingya, but also all the people of Myanmar collectively. Nationalists view themselves as potential victims to oppression at all times in several spheres and it seems like the easiest target to conquer is the already weak, unarmed and isolated Rohingya and other Muslim minorities. These groups are easy to target because they do not have an army, or even any intent of actually making Myanmar Muslim as the nationalists claim. If they did, would they not have ISIS or other terrorist groups backing them for Islamization of Myanmar? Rohingyas are immutably foreign and Muslim—-that is, they are labeled with an identity convenient to state-sangha

oppression - they are always a target of violence and now even victims of violence, while always being accused of being perpetrators of it.

\section{Fitting the Criteria for Genocide}


The 1982 Citizenship Act and current political inaction to change or adjust it has created a framework for a slow genocide of the Rohingya. Article 2(c) of the Genocide Convention of 1948 states that deliberately inflicting conditions of life calculated to bring about physical destruction is one of the five acts of genocide (Zarni and Cowley 2014). Zarni and Cowley (2014) outline four mechanisms carried out against the Rohingya that fulfill genocidal criteria. The four criteria are outlined as follows:

1. Violence, forced migration and illegalization constitute intent to destroy the Rohingya.

2. Imposed marriage and birth restrictions are discriminatory population control measures intended to prevent Rohingya births.

3. Deliberate destruction of the social foundations of the Rohingya as an ethnicreligious group inflicts on the Rohingya conditions of life calculated to bring about the group's physical destruction.

4. Intent to destroy the Rohingya through erasure of their identity and history.

After the 1978 exodus and displacement of the Rohingya came the 1982 Citizenship act that stripped them of their legal identity in Myanmar. However, the act also serves as a framework for the implementations of travel restrictions, bans on marriages and cohabitation with legal citizens, as well as restrictions on access to healthcare and education. Simply put, this makes the Rohingya stateless. To be stateless is to be deprived of legal protection and to be susceptible to poverty, abuse, extortion and exploitation (Zarni and Cowley 2014, 707).

Other waves of large scale violence and forced migration occurred between the 1990’s and 2000’s. In 1992, the security forces “NaSaKa” (part of the junta regime) wreaked havoc on the Rohingya during the NLD's blatantly ignored win in the elections. There were land confiscations, forced evictions, forced labor, torture and rape across the Rakhine state that affected the already impoverished Rohingya and even Buddhist 
Rakhine citizens who supported the NLD as well. This caused another 250,000 Rohingya to flee and 236,000 of them were returned by Bangladesh and thrown into camps with illegal Bengali immigrants (Zarni and Cowley 2014, 711).

In 2001 and 2002 twenty-eight mosques were burned down resulting in the death of many Rohingyas once again. Although the government did not incite all these acts, it always supported them. We still see this today, as Thein Sein stays mum about the hatred spread by Wirathu against the Rohingya and Muslim community. Allowing hate campaigns to occur, revering monks like Wirathu as "the son of the Buddha” and leaving civilian mobs unpunished for committing hate crimes affects the Rohingya as negatively as giving the order to exterminate them. As Human Rights Watch (2013) comments on the matter, violence is

...organized, incited, and committed by local Arakanese [Rakhine] political party operatives, the Buddhist monkhood, and ordinary Arakanese, at times directly supported by state security forces. Rohingya men, women, and children were killed, some were buried in mass graves, and their villages and neighborhoods were razed. While the state security forces in some instances intervened to prevent violence and protect fleeing Muslims, more frequently they stood aside during attacks or directly supported the assailants, committing killings and other abuses. In the months since the violence, the Burmese government of President Thein Sein has taken no serious steps to hold accountable those responsible or to prevent future outbreaks of violence.

Additionally, any locals who attempt to try to help the Rohingya are publicly shamed and at risk of falling victim to violence as well. In February 2014, Doctors Without Borders was forced out of Myanmar by the government after staff had already abandoned their mission due to the threats from mobs (Zarni and Cowley 2014, 717). I learned this quickly when I contacted several diplomatic agencies to inquire about volunteering to 
aide the stateless Rohingyas. I was advised to not go anywhere near Rakhine for my own safety.

In 1993, Myanmar also imposed marriage and child-bearing restrictions on the Rohingya as part of state policy to restrict the growth of the Rohingya population, citing that the growth of the Rohingya imposes a future threat to peace and public order. These laws, in addition to the inaccessibility to adequate healthcare and education for the Rohingya, are a tactic for the destruction of the Rohingya from all angles. Additionally, some of the educated ${ }^{17}$ Rohingya class has been targeted in the last three decades as well. In 2012, a Rohingya doctor (a man, 65 years old) and a retired lawyer (a 75-year-old woman) were both imprisoned for trying to help the community during a Buddhist attack. Several children ages 11-16 were also arrested during the attacks. In contrast, no Rakhine Buddhists were arrested (Zarni and Cowley 2014). Many recorded testimonies of Rohingyas who successfully escaped Myanmar repeat the same narratives stating that the Burmese government would brutally beat them, force them to say they were Bengali and accuse them of crimes they did not commit (Zarni and Cowley 2014). These narratives are so similar to what Angela Davis (1981) describes when she retells the tales of American black men abused by authorities prior to the civil rights movement. I will address these narratives in detail in Chapter 4 along with analysis of thesis material.

\footnotetext{
${ }^{17}$ During the country's early independence period (1948-1958) several Rohingya were able to lead normal lives as citizens. They were included as parliamentary secretaries, cabinet ministers, members of the parliament, well-to-do merchants, scholars, writers, artists, broadcasters, journalists etc. Under Ne Win's rule the new generation of Rohingya were denied citizenship and opportunities to study medicine, engineering, and other tertiary/university level subjects considered professional subjects as opposed to arts or pure sciences (Zarni and Cowley 2014).
} 
The state supported destruction of the Rohingya's culture and identity is by far the worst case of abuse in Myanmar. They are dehumanized and stigmatized to ensure that their lives never amount to more than what they are bred to believe they are by the Burmese. I ask, how can anyone who claims to be a compassionate Buddhist support this behavior? In the 1950's Burma wanted to decrease the stray dog populations in Rangoon. The sangha recommended the locals leave poisoned food out for the stray dogs to consume. In order to comply with Buddhist ideals, only some of the meat put down was poisoned. Therefore, the dogs had a choice. If the stray dog chose poison, the Buddhists believed that was the dog's kamma (Harvey 2000, 167). The same kamma concept was applied to another instance when there was a great ground rat infestation. The monks told villagers that killing the rats would be an evil. However, killing the rats was unavoidable given the need to harvest crops. Therefore, any money donated to the sangha from the increased profits as result of the rat killing would, in turn, provide good kamma for the farmers (Harvey 2000, 168). This spiritual money laundering creates an illusion of sacrifice for the sake of the greater good. However, in the case of the Rohingya, there are realities of massive bloodshed to be addressed once we remove the karmic saffron coat of paint.

For me, there is a difference between those who commit and justify the violence and those who are silent, allowing it to occur. The ones who stay silent may be afraid of the consequences they would have to pay for defending a culturally marginalized group. After all, many have paid severe consequences for disagreeing with governmental decisions. Some speculate this is why Suu Kyi has remained silent on the issue of the Rohingyas, although Maung Zarni seems to disagree. Zarni (2016) critiques her silence 
and pro-Suu Kyi speculation that suggests she is taking a pragmatic approach in order to avoid losing the momentum that came with the NLD's election victory in November 2015. He claims, Suu Kyi’s dismissive attitude toward the Rohingya’s plight as genocide is unacceptable for someone as morally regarded as she is (Zarni 2016).

Is there a way to differentiate the physical, verbal and micro-aggressions on a karmic level? According to the karmic loopholes such as the one of giving the dogs a “choice” or making donations with profits from the ground rat killings, this "anti-colonial nationalism degenerating into xenophobia” seems to think there is (Harvey 2000, 283). One can still be Buddhist and allow the Rohingya to suffer their "chosen” path. This is especially true when the face of the greatest oppressor is a Buddhist monk acknowledged as so and supported by the government. Like the head nun from Sakyadhita said, "If the sangha says he is a monk, he is.” It would be much too risky to publicly go against a monk in robes, such as Wirathu.

\section{Conclusion}

The problem with Buddhism at the front and center in Myanmar's ethnic, political and religious conflicts is that it asserts itself as the "right" ideology of the land, practiced by the majority even in the times of adverse secular British rule. This leaves many minorities who are outcaste to suffer a plight of marginalization. Minorities must succumb to parting ways with their roots as in the case of the Rohingyas, who could not even claim their ethnicity in the national census without risking their lives. The Mon and Karen refugees I worked with in 2013 in Sangkhlaburi, Thailand became stateless in Thailand after they were trafficked and enslaved for months on their way out of Myanmar. Others, such as 
the Kayan ("long neck") women have to resort to being exploited as side shows for tourists in order to survive.

It seems as though the 969 and its supporters do not consider the Rohingya as sentient beings or more so they disregard the effects of their actions toward them because the protection of the sāsana plays a more important role. Judging from the reactions of locals to people who aide the Rohingya, it is obvious why no one seems to risk their lives to get involved. To side with the marginalized population marginalizes the individual siding with them. I also believe that because this marginalization has been going on for so long and Myanmar lags behind the rest of the world in communication and accessibility to education, it is difficult for the bystanders to be compassionate about something they barely know anything about. Ironically, this is an example of the Buddhist teaching that states, "ignorance and dogmatism are at the root of much human suffering” (Harvey 2000, 283). 


\section{CHAPTER 4}

Analyzing Myanmar’s Xenophobic and Misogynist Discourses and Actions According to Bourdieu (1977), when an individual (agent) enters the multidimensional space that is society, which he refers to as existing in fields, the agent brings with them a habitus. Habitus is a combination of the amount and type of capital the individual has accrued in their lifetime. This capital can consist of economic, social or cultural capital. All these factors then create symbolic capital, which tends to happen automatically when the agent enters a field. These fields all have doxa which can be easily understood as taken for granted rules in the society, but more so "the universe of possible discourse" (Bourdieu 1977, 167). Doxa determines one's sense of belonging and what is right and wrong in each field. This term is fundamental to my research as doxa is precisely what Wirathu spouts based on his generalized perceptions of what all Muslims are (ISIS). He is abiding to his doxa in Myanmar due to the small scope of his own habitus and lack of exposure to other practices of Islam.

Wirathu, the Rohingya and Burmese women all adhere to the doxa circumscribed to them as natural order, but they are all politically and socially constructed to benefit a specific type of agent. Specifically, agents in Burmese society are conditioned to empower the ruling regimes, both monastic and government. Women are instruments for the government and the sangha. As long as they remain the weaker, less intelligent and less successful sex they can be used as a justification for invasive actions that are disguised as protection. The Rohingya must remain an enemy agent in order to justify their depopulation by the Buddhist. However, none of this applies to any of these agents outside of the Burmese society. To exist is to exist in relation to others. What is real is 
relational and everyone understands the world by marking differences in observed phenomena (Bourdieu 1977).

Wirathu has not accepted any evidence provided that contradicts his belief that the Rohingya (“Bengalis”) are not harmful to the continuance of Buddhism in Myanmar. Additionally, he will not accept that women are as capable of attaining full ordination as often and as easily as monks do. Nor will he accept that a woman who wants to partake in an interreligious marriage is doing it on her own free will, but instead by the force of the Muslim husband. For Wirathu, his cognitive dissonance is a protective shield for the capital he accrues for the role he plays as an agent of Buddhist nationalism. In terms of Buddhist nationalism here we see a "hegemonic domain of nationalism” (Chatterjee 1993, 74). He accrues symbolic power as a wealthy Burmese monk and this sets the standards of his doxa. Thus to retain his symbolic power he must magnify possible threats to Buddhist nationalism (the doxa), and defend it vigorously. Anything that challenges Wirathu's position as a nationalist religious leader is not allowed to enter his field, as we have seen with his generalization of Rohingya as ISIS or Bengalis despite empirical evidence proving otherwise. He has symbolic capital as a religious leader and his symbolic violence wields that capital against the Rohingyas. Therefore, to accept that the Rohingya are not a threat to the Burmese and Buddhism is to lose capital. He is aware of his bigotry against them and uses it and support for stalling the democratization process to consolidate power for him. Given the overwhelming support for the NLD, one wonders if his capital will prove enough to hold off the NLD.

Wirathu's disregard for women as capable of making their own decisions to marry inter-religiously if they choose, or as possessing the ability to become fully 
ordained Buddhist nuns, reflects another aspect of Myanmar doxa. Buddhist women and nuns in Myanmar are also agents who at the same time abide by doxa concerning the accepted roles of women, in which they are trained from early on during their upbringings. This doxa is also shaped by women's lack of access to both secular and Buddhist education, thus reinforcing Wirathu's claims that the Burmese people are uneducated and naïve.

As a secular feminist from the West, I acknowledge my privilege to have the room to deny that it is "protection” that nationalists in Myanmar offer to their society's women. Mahmood’s Politics of Piety (2005) has been fundamental to my research in its groundbreaking analysis of women’s attempts to assert themselves in male-dominated spheres. I am appalled by gender inequality and ethnic-religious based genocide and consider myself fortunate to have a soapbox to stand on as an American university graduate student. I also found Angela Davis’s Women, Race and Class (1981) to be surprisingly helpful for this work as she addresses the "Myth of the Black Rapist.” I find that it resonates well with Wirathu’s accusations of "Muslim rapists."

\section{An Analysis of U Ashin Wirathu's Discourse and Actions}

Walton and Hayward (2014) provide a noteworthy analysis of nationalist rhetoric among Theravada Buddhist monastics in Myanmar. They identify five reoccurring themes within the Buddhist discourse in Myanmar: rumors and fears about Islam and Muslims, the defense of the śāsana, the use of "non-Buddhist” methods, the claim that nationalist

groups merely promote Buddhism, and the denial of responsibility for violence associated with the movement $(2014,17)$. I have chosen to expand upon Walton and Hayward’s 
reoccurring themes with commentary from my own research and findings. Walton and Hayward greatly contributed to the choices I made for my interview questions as I set out to expand on the answers Wirathu previously provided in their work in terms of justifications for the 969's opposition to Muslims and violence against the Rohingya.

Wirathu claims that there is a Muslim conspiracy in Myanmar to exploit the country's economic capital and convert all its women through interfaith marriage. This argument is faulty; he is generalizing about the Rohingya based on stereotypes about their religion, to which several incidents perhaps lend credence as "cases in point.” This narrative has created a mentality of fear among Burmese Buddhists. Ashin Sada Ma, the Buddhist monk who claims he created the 969 logo, stated, "Only small parts of Asia are Buddhist now; in the past, Indonesia, Bangladesh, Afghanistan, and many other places, including Turkey and Iraq, were Buddhist countries, but now they are lost” (Galache 2013). Wirathu supports this argument by stating that all of Myanmar will be like the Mayu region in Arakan state by 2100 if they do not do anything to stop this now (Wirathu 2015). Although those countries are in fact predominately Muslim at the moment, they were not all Buddhist countries prior to the spread of Islam. Indonesia and Bangladesh were predominately Hindu before the advent of Islam, and Afghanistan was predominately Buddhist following Asoka’s invasion.

When Wirathu is asked for rhetorical support for driving out Muslims, his response is: defense of the śäsana. Buddhists such as the 969 monks or Ma Ba Tha defend their actions in the name of protecting the śäsana, disregarding the detrimental effects of their actions upon the victims. Buddhist texts are ambiguous in regard to humanity and virtue (Jerryson 2013, 43). I provided examples of this in the context of 
Burmese Buddhist ethics and the way they justified the killing of rats and dogs through what I refer to as "spiritual money laundering." This mentality resonates with the text composed in Sri Lanka, the Buddhist Mahavamsa (The Great Chronicle). In this text the Buddhist king Dutthagamani wages a just war against Tamil invaders. After his victory, Dutthagamani laments the slaughter of millions and eight arahants come to comfort him (Jerryson 2013, 43).

From this deed arises no hindrance in thy way to heaven. Only one and half human beings have been slain here by thee, $\mathrm{O}$ lord of men. The one had come unto the (three) refuges, the other had taken himself the five precepts. Unbelievers and men of evil life were the rest, not more to be esteemed than beasts. But for thee, thou wilt bring glory to the doctrine of the Buddha in manifold ways; therefore cast away care from thy heart, $\mathrm{O}$ ruler of men! (Geiger 1993, 178)

These verses refer to several monks who defrocked in order to fight for the kingdom. The Sinhalese king, Dutthagamani, experienced remorse after the massacre. He was then visited by eight arahants who told him not to worry. They said, "Only one-and-a-half people died in the war” (Geiger 1993, 179). This text is micro-aggressive in content as the arahants are dehumanizing non-Buddhists. According to this text the "one person" is the person who took five precepts. The "half" refers to one who took lesser precepts and therefore was not considered a full Buddhist and therefore only half human. Conclusively, in this Sinhalese text, without taking the Buddhist precepts, one is not a human whose life counts.

The issue for me here is that a text like this appears to disregard human life altogether, though it can also be understood as an example of detachment depending on who is interpreting. The previous passage I quoted in Chapter 3 from Bhikkhu Silacara's Burmese rendering of the Buddha's life, in which the bhikkhu was willing to die an 
honorable death if killed by the wild ones because it meant he died spreading Buddhism to non-Buddhists, like the one above shows a few examples out of a number of religious texts and practices that support violence in the cause of Buddhist nationalism, especially the creation of heroes. This support disregards the lives of non-believers and makes martyrs of those who die for the spread of the religion. This rhetoric defending religious uses of violence is repeated throughout history, in many religions, and is widely used today by terrorist organizations attempting to consolidate their versions of their respective religions on a national and, in some cases, global scale. In the case of the 969 and Ma Ba Tha, the distinction between defense and force often blurs in their actions against the stateless and impoverished Rohingya community. However, this rhetoric is all conditioned knowledge and practice of rhetorical violence.

The use of non-Buddhist methods such as name-calling and encouragement of violence among the laypeople is a tactic protected by the denial of intent. In an interview with Walton $(2013,24)$, Wirathu was adamant about stating that all his sermons "are consistent with the pitaka." He also claimed that he follows the path of the hpaya-laung (Metteyya, the future Buddha). I received similar responses when I questioned his actions. The 969's pamphlets are contradictory, as they state that the community must urgently protect the śásana, race and country from the Muslim community while it provides a code of conduct that condemns killing (Walton and Hayward 2014, 24). Wirathu insists on the precept of non-violence as key to the monastic code of conduct as proof that he is not inciting violence. In any case, if murder does occur, according to the Burmese Buddhist rationale for ethics I have presented, if it is in the name of Buddhism, it does not accrue bad karma for the actor and is considered a righteous act. 
Burmese monks and supporters of the 969 Movement commonly deny responsibility for the violence the Buddhist community inflicts upon the Rohingyas because they claim they did not intend violence. After these hate-filled discourses are spread there is a tendency to call those who perform the violence "naïve or undereducated Burmese” (Walton and Hayward 2014, 28). Walton and Hayward agree that this deflection of responsibility is attributed to the meaning of kamma for the Burmese Buddhists. Walton $(2014,29)$ states, "While the word karma simply means "action,” the Buddha virtually redefined the term from ritual action to volitional action.” That is, intent determines the karmic impact of all actions. By clinging to intent, Wirathu points out that he has never commanded any of his followers to kill. He blames the lower level Burmese for such matters and declares that his speeches simply aim at keeping Buddhism and Burma pure. His intent may be for protection of the Buddhist sangha in Myanmar, but he must now be aware of the likelihood of violence toward the Rohingya by his followers who feel they carry out his agenda. It is true that although Wirathu's video recordings filled with hateful messages are degrading and condescending to the Rohingyas, he has not demanded that the community murder anyone. There have been many incidents in which he insisted that although there were 969's spray-painted on remains of mosques and homes burned to the ground, the culprits did not work for him. Whether or not they are under his command the spray-painted 969 is the symbol of power he created and it serves as empirical evidence for Wirathu and observers that this movement inspired the culprit's actions. 


\section{Theorizing Women in Myanmar}

With Buddhism serving as the central marker of what it is to be ethnically Burmese, specifically among the nationalists and nationalist monastics, we must acknowledge how power manifests through the religious institution in Myanmar and its fundamental influence in society’s treatment and views of women throughout history. As I have discussed, Theravada Buddhism in Myanmar has impacted the legitimization of the social hierarchies among the sexes by asserting male superiority on an otherworldly level. My findings suggest that the Buddhist nationalist claim that a dreadful other has infiltrated the society has been a reoccurring theme within Burmese history. In that same history the feminine gender has at times served as the scapegoat to hide Burmese males' failures at keeping the purity of their culture. That is, women have been portrayed as the weakness that allows the other to infiltrate and undermine the culture, religion and nation. Thus control of women has been seen, and continues to be seen, as a primary method of protecting both women and the religious culture for those who seek this Burmese Buddhist "purity.”

Burmese literary sources and legal texts also historically support female subordination. The Lokanitti, a treatise on the world's nature written in the eleventh century, was taught in many monastic schools in Myanmar and provided a behavioral

guide for women. The author described a good woman as “devoted to her husband,” and as one who "respected him like a slave” (Harriden 2012, 25). Additionally, Harriden points out another source, the Manugye Dhammathat (Burmese customary law codes), which states that a good wife acknowledges that men are closer to Buddhahood than women and therefore as a woman she must say to herself, "I, being a woman, shall have 
to strive hard to be first re-born as a man” (Harriden 2012, 25). This resonates with Buddhist karmic doctrines and Daw Nang's repeated wish to be born a male.

During my fieldwork, I came across references to the nat worship of the Queen Saw Mon Hla quite often. Most male monastics whom I asked frown upon nat worship. After I described the nat worship ceremony at the Rose Pagoda in Mandalay, Panna Jota was so intrigued as to what I witnessed that he bought himself some literature on Saw Mon Hla. Daw Nang, on the other hand, stated that it was "village people worship" and not commonly practiced within more cosmopolitan society. My experiences in watching and participating in this nat worship among Buddhists and animists is beyond the scope of this thesis. However, it is germane to this thesis that I often heard snickering claims that the women who get possessed by the nat spirit are weak-bodied. I saw only women, never men, tumble around on the concrete floor with their eyes rolling to the backs of their heads as they invoked the spirit, perpetuating for many the stereotypes of feminine weakness and undisciplined nature, as Kawanami $(2013,144)$ references in her own accounts about spirit possession.

According to Candasiri, the nat, Saw Mon Hla, was the respected wife of King Aniruddha of Bagan (Pagan) who, ironically, founded the ancient city of Bagan and demanded the implementation of Theravāda Buddhism across Myanmar in the eleventh century, as mentioned in my brief treatment of the history of nationalism in Myanmar in Chapter 3. The actual lives of nats refer back to a time when women played important roles. For the most part these attitudes toward women as important tend to be ambivalent. Nationalists claim that these stories demonstrate that Burmese women were respected as queens and say that women have traditionally held high status in society as wives and 
mothers. However, such arguments were developed mostly to bolster Burmese claims to independence from the British due to the colonialists' references to Burmese women as subservient. Simultaneously, the Burmese were highly critical of women who married foreigners, claiming it weakened their Burmese ethnicity (Harriden 2012, 10).

Colonial officials cared little about the effects of marriages unless they were British-Burmese unions. It was after the advent of colonial rule that Indian and Burmese marriages became more common. This was the beginning of nationalist concerns for women's inheritance rights. Mostly, the lack of concern stemmed from the colonial belief that giving women inheritance rights provided them with too much power. Traditionally, the dhammathats provided women with the rights to work and to control their own finances. However, the polygamy common in Pagan society, as sanctioned by law, increased inequality (Harriden 2012, 58). Still, Burmese customary law at the time of the British invasion stated that women had an equal share of anything acquired during the course of a marriage, and divorce could be obtained by mutual consent (Harriden 2012, 115). British law gave women no property rights at all—husbands owned and controlled all of their wives' property, and this was considered the proper way to protect women from responsibility they were not capable of carrying. The British then implemented The Special Marriage Act of 1872, which required that women renounce Burmese customary law if marrying non-Buddhists. It put them on a pedestal as Buddhist wives and mothers while it stripped them of their rights if they married non-Buddhists.

"Protection of women" has long been the slogan for disempowering women. Like Burmese Buddhist women, Muslim women had stronger property rights than any western women in the world until colonialism, even though Islamic law in many nations had often 
watered them down over the centuries. The Qur’an (4.32) states, "Whatever men earn, they have a share of that and whatever women earn, they have a share in that.” This is the irony in Wirathu’s wanting to protect Buddhist women from Muslim culture. For him, women who marry Muslims abandon their status as Buddhists and birth more Muslims. Therefore, they jeopardize the status of Buddhism in Myanmar by creating more Muslims and denouncing their own Buddhist status. It is important to note that I am not valorizing Islam or demonizing Buddhism here. The persecution of the Rohingya is unjust as is the subordination and instrumentalization of women in Myanmar. This is simply an observation of both religious institutions and their paradoxical interpretations and uses for power dynamics in a political sphere.

During the period of colonial annexation and agricultural and commercial expansion, the peasantry was essentially lost. Locals found themselves competing with Chinese and Indian labor workers willing to work for lower wages. Machine-made textiles began to take the profits of the Burmese handmade goods made by the locals. In essence, to join the rising nationalist movement meant boycotting foreign products in order to strengthen their own economy (Harriden 2012, 117).

This embedded a fear in men of the disintegration of culture by others. Men felt like they were not only losing their women to Indian foreigners, but also economic roles to their Indian husbands. This fear is still present in Wirathu’s discourse about Muslim businesses and interfaith marriages. To add to this reiteration of fear-inspired misogyny and xenophobia, Harriden cites an article published in November 1938 in Seq Than,

You Burmese women who fail to safeguard your own race, after you have married an Indian, your daughter whom you have begotten by such a tie takes and Indian as her husband. As for your son, he becomes a half-caste 
and tries to get a pure Burmese woman. Not only you but your future generation also is responsible for the ruination of our race (Harriden 2012).

This article gave rise to nationalist movements across the country, which in turn helped Burma break free from colonial rule. Perhaps it is because of historical movements like these that Wirathu and his cronies continue to gain power through the use of women as scapegoats as it has been successful in the past with other aforementioned nationalist movements (see Chapter 3). We see here that women were tempted with traditional divorce, property rights and inheritance rights by the Burmese nationalists in return for their allegiance to their fight against foreigners. However, there was a catch, just like there is today for their allegiance. There really is not a choice since what the nationalists did was to take away their rights as Burmese women if they did not marry Burmese men. Essentially, there really is no protection unless Burmese women do as Burmese men tell them to do.

I believe that Buddhist narratives read by the saya-leis and Candavara also heavily influence this mentality, which time and time again addresses women with such ambivalence. Sponberg (1992) referred to the Jätaka stories as "the most blatantly misogynous of the Pāli literature.” Both Candasiri and Candavara mentioned one passage in particular to me. The Kunāla Jātaka states:

No man who is not possessed should trust women, for they are base, fickle, ungrateful, and deceitful. They are ungrateful and do not act as they ought to; they do not care for their parents or brother. They are mean and immoral and do not do only their own will.

Though a man may be their loving, kind and tender companion for a long time; though he may be dear to them as their own life, yet in time of distress and misfortune they leave him. Therefore, I do not confide in women. The mind of women is like that of a monkey, going from one place to another, like the shadow of a tree. The heart of a woman is 
unsteady like the rim of a wheel. Women are [sticky] like gum, are all devouring like fire; they are clever deceivers and impetuous like a river. They go both to the man they love and to him they dislike just as a boat goes to both banks of a river. They do not belong to one man or two: they are laid out like goods in the bazaar. He who should think, "they are mine" might just as well try to catch the wind in a net (Bollee 1970, 160).

As I discussed above, at times women are praised as mothers. In other instances women are labeled undisciplined temptresses, as in the depiction of women in the Jātaka stories, wherein women are regarded as composed of wickedness and deceit (Harriden 2012, 24). Although women are sometimes regarded as such, their roles as mothers benefit their families and communities so they are also revered as merit-making entities. Women become saya-leis, because even if they do not fulfill the roles expected by society as mothers, they can still practice merit-making for the community and provide a service to men. Still, even in the position as saya-leis, they will never be equal to a monk nor provide the same merit in their entire lifetimes as a male novice in Burmese society.

I do not see a problem with women being regarded as mothers, but I strongly oppose the lack of options provided to Burmese women if they choose not to be mothers or wives. While some women, like Daw Nang, claim they do not need feminism in their society, does the fact that she desires to reincarnate as a man contradict her claim? In this case, I think her response to feminism is a cultural doxa for her provided by the nationalist Burmese Buddhist field. Her support of the inter-religious ban on marriage is also a conditioned response to her belief that women need "protection” from Islam. Daw Nang's position is also a symbol of liberation because she is present in a male dominated sphere as a widow and successful middle class English speaking primary school owner. During my time in Myanmar it was rare to see a woman with Daw Nang's success in a 
man's sphere, as a building and school owner. This translated as a form of transnational feminism. Mahmood claims, “...women are seen to assert their presence in previously male-defined spheres while, on the other hand, the very idioms they use to enter these arenas are grounded in discourses that have historically secured their subordination to male authority” (Mahmood 2005, 6).

Despite my western feminist ideals, through which I view their status as subordinate, I can recognize that Daw Nang and the nuns of Sakyadhita, who refuse to take part in these political dilemmas, lead successfully Buddhist lives. However, it is important to note that the key ingredient for their lack of oppression is financial stability; recall that the head nun at Sakyadhita stated, “The nunnery is not affected by political issues because we are cut off from the outside world as nuns and we receive most of our donations from foreign Buddhists.” Thus, full ordination and interreligious marriage laws do not directly affect Daw Nang and the head nun at Sakyadhita because their ability to resist the patriarchal and subordinate standards that nationalist Burmese Buddhism imposes on them is based on their financial capital.

Mahmood (2015, 13) goes on to describe the 1970's white middle-class feminists' call to dismantle the nuclear family which they believed was a key factor to women’s oppression. Native American and African American feminists could not stand behind this, as years of oppression by whites had deprived them of the freedom to create families and social connections (symbolic capital) that stem from their growing communities. As it was then in America, ethnicity, race and socioeconomic status are all interrelated with the oppression of women in Myanmar. Individual autonomy goes further than full ordination status or the right to maintain Burmese customary marriage laws even if one 
chooses to marry outside of Buddhism. However, the choice to lead the life one desires should be available only as long as it does not cause harm or endangerment to another group. In the case of the ban on interreligious marriage or full ordination for women, the only thing at risk is the dominance of males over females in Buddhist practice and political power through social supremacy in terms of both gender and ethnicity.

Myanmar's government perpetuates these ideas as well with the help of radical monks like Wirathu. During my fieldwork the government and Wirathu were lobbying for the ban on interreligious marriage as well as several other laws pertaining to women's rights. Maber (2014) provides a comprehensive list of issues that contradict women's rights in Myanmar:

1. There are no specific laws to protect women from domestic violence.

2. Abortion is illegal except to save a woman's life.

3. Marital rape is not criminalized unless the wife is younger than 14 .

4. Lack of standardization of marriage laws that vary by religion of spouses.

5. Greater restrictions apply to women seeking divorce (laws cater to men).

6. There are no harassment laws in the workplace.

7. There is no provision for parental leave.

Through interviews with 43 female leaders (members of political parties, local and international NGO’s and local-level community-based organizations), Maber (2014) adds that it is very difficult to be taken seriously as a female leader in Myanmar because men do not want to hear women speak unless they agree with them, so that accessibility to a large audience is usually prevented. This information is fundamental to understanding the current state of affairs that has plagued Aung San Suu Kyi throughout her attempt to turn Myanmar into a democracy. 
The problem with the Myanmar judicial system is not that the customary laws have not been drafted and set. Instead, the problem is the scarcity of legal training outside of the military regime (Maber 2014). With a majority of former junta comrades running the system anyone who does not fall under Buddhist Burman gets shafted in terms of justice. Additionally, women's low levels of civic engagement contribute to judicial accommodation to males (ibid.). I discuss in further detail the inequality of justice by the Burmese government against women and minorities specifically, the use of rape as a weapon and scare tactic, in the next section.

The previous junta regime utilized rape as a form of aggression toward minority women as I witnessed through my work with victims rescued in Thailand. Although Myanmar has declared that it is working toward democracy, the same military junta officials that implemented and turned a blind eye to ethnic depopulation of minorities and used rape as a weapon of war still fill the majority of parliamentary seats, with 398 reserved for military officials (Maber 2014). The military also has the 969 Movement's support, as I observed when the military in parliament denied Aung San Suu Kyi the right to run for president. Wirathu gloated about it via his Facebook page as a victory for the now former government, Ma Ba Tha and $969 .{ }^{18}$

\section{The Myth of the Muslim Rapist}

In June 2012, Thida Htwe, a Buddhist woman, was raped and murdered allegedly by three Muslim men in Rakhine state. Several Buddhists distributed incendiary 969

\footnotetext{
${ }^{18}$ I address the changes to Myanmar's current government in the conclusion of Chapter 4.
} 
pamphlets detailing the rape and a retaliation followed by the killing of ten Muslims on a bus. The three Muslim rapist-murderers were already in custody by the time the hatecrime was committed on the bus. This rape and murder caused riots that led to more Muslim bloodshed and destruction of property. The men responsible for the Muslim deaths were not arrested and the three men who raped the Buddhist woman were sentenced to death and executed in June 2012 (Human Rights Watch 2012).

On July 1, 2014, Reuters reported that one Muslim and one Buddhist were killed during a riot caused by allegations that a Muslim man raped a Buddhist woman (Ferrie and Tun 2015). The rape claim was later proved to be untrue and the woman, Phyu Phyu Min, was convicted of filing the false complaint along with the 4 others who bribed her and organized the anti-Muslim riot. This same article acknowledges that the rape narrative is used often when Buddhists intend to incite violence against the Muslim community in Burma. The official who made the statement to Reuters, however, refused to provide his name and identifying information of his position within the government because he is not allowed to speak to the media (Ferrie and Tun 2015). I have seen this myself in several translated versions of Wirathu's speeches found on YouTube. The rape narrative is often present. In two separate interviews held by Walton (2013) and Juergensmeyer (2014), Wirathu stressed the same claims.

The military personnel did little to stop the riots while they were occurring yet they were quick to make arrests after the fact. Through my work at Baan Unrak on the border of Thailand and Myanmar, I worked with victims of rape and human trafficking; most of the culprits were government officials. The Reuters report claims some of Wirathu's monks were actively trying to control the crowds during the riots, which is 
paradoxical because Wirathu encouraged the riot on his Facebook page (Ferrie and Tun 2015). It seems like the government and Wirathu are practicing behavior for which the closest term to describe it for me is the Japanese term, honne tatamae. ${ }^{19}$ Not surprisingly, Aung San Suu Kyi was expected to arrive in Mandalay to campaign for constitutional change that week. Here, the Buddhist nationalists pose a threat to democratic actions proposed by the NLD such as feminist groups and Suu Kyi's opposition to the ban on interreligious marriages proposed by current president, Thein Sein (and supported by Wirathu).

The Shan Women's Action Network (SWAN) and Shan Human Rights Foundation (SHRF) reported 173 rapes of women and girls committed by military in Shan State between 1996 and 2001. There were no convictions and no crisis support was offered to the victims (Moe 2015). In January of 2015, two Kachin state volunteers who were volunteering for the Kachin Baptist Convention (KBC) were raped and killed in the northern part of the state, where the Myanmar army is at war with the Kachin Independence Army. No arrests were ever made and the government made a public statement that anyone accusing the military of being the culprit would be imprisoned (ibid.).

Angela Davis (1981) brought to light the lack of justice that plagues Black ${ }^{20}$ men accused as rapists while the white man's rape crime was consistently swept under the rug.

\footnotetext{
${ }^{19}$ Honne tatamae is a Japanese term - honne meaning the real self or true feelings and tatemae meaning the facade.

${ }^{20}$ Angela Davis always capitalizes the word Black. Out of respect for her, I have decided to observe her capitalization when referencing her work.
} 
She asserted that the myth of the Black rapist caters to upper class patriarchy insofar that it was only in place to protect white women and convict Black men. She stated that the white man's rape of the slave was so highly ignored that no one was ever held to justice and white on black rape continued even long after the abolition of slavery. Davis (1981, 173) claimed,

In the history of the United States, the fraudulent rape charge stands out as one of the most formidable artifices invented by racism. The myth of the Black rapist has been methodically conjured up whenever recurrent waves of violence and terror against the Black community have required convincing justifications.

These myths were created to justify continued abuse of the Black community long after the abolition of slavery. The white man had an economic incentive to rape Black women, in that he would own any children born of the rape just as he owned the mother. As Davis puts it, "they are immune to prosecution because they commit their sexual assaults with the same unchallenged authority that legitimizes their daily assaults on the labor and dignity of working people” (Davis 1981, 200).

In Myanmar, the Black rapist is the Muslim rapist. The rape of Buddhist women is a concern. Yet, the plethora of reported rapes by military personnel of ethnic minorities for the last four decades goes without prosecution. Similar to the Black community in pre-Civil Rights America, the ethnic minorities in Myanmar are mistreated, ostracized and trapped in order for the nationalist Buddhist class to continue to thrive. They call this the protection of the śāsana and Buddhist women. Additionally, Davis (1981) refers to Lerner's observation that the myth attached to the Black woman as "bad Black woman" who was promiscuous is the twin of the Black rapist - both were designed to apologize for and facilitate the exploitation of each. For Myanmar, the myth attached to Muslim 
women is that each woman is oppressed and "one of many wives" as Wirathu and Candavara both explained to me in separate interviews.

\section{Habitus, Symbolic Power and Violence}

According to Bourdieu, space has no meaning when separated from practice. Habitus, which structures dispositions, constitutes and is constituted by agents through practice (Bourdieu 1977, 24). That is, what is said within Wirathu's monastery shapes the monastery itself, whilst his robes represent Buddhism despite his preaching nationalism and prejudice. Wirathu wields symbolic power and is aware of that fact, yet denies it to the western public during interviews with media and scholars. However, his repetitive discourse referring to the Burmese as naïve and undereducated serves as significant proof of his awareness that the mobs are easily aroused. Thus, leaders must be cautious about arousing them. Instead Wirathu tends to redirect blame for the violence against the Rohingya to the undereducated Burmese. I posit that his claims that his intent is not to ignite violence upon the Rohingya, he cannot be unaware of what his speeches incite amidst the "naïve and undereducated" Burmese people. Symbolic power is always power over another, so the object upon whom the power is wielded is the victim of "symbolic violence.”

Faure claims that the only tolerance that seems to increase among the violent Buddhists in Southeast Asia is the tolerance of "banalized violence" (2010, 223). Although their ethical absolutes against killing are still present, Buddhists like Wirathu practice nationalist Buddhism in order to preserve Myanmar and Buddhism against Islamization prior to and above any other ethical values. Religion thus plays an ancillary 
role to nationalism. Value inversion such as this is common among the fundamentalist and terrorist groups that wreak havoc around the world. Value inversion also coincides with the role memory plays in the Burmese community regarding their recent independence, first from British colonialism and then junta rule. The community, including Wirathu, is still in a state of adjustment concerning what it means to be independent, and is shaken by the fear of oppression and poverty that previous regimes have imposed upon the country for hundreds of years.

Within the notion of habitus, Bourdieu $(1977,24)$ explains that history is the embodiment of innate responses from the field's agents. In this case, the field is Burmese society and the agents are the nationalists. Religious principles and history tend to get lost in the translation of culture and innate performance in the field. The regime has controlled the field for a long time, dictating the performances that citizens have acted out time and time again, until those performances become part of who they are.

The meaning of what it is to be a "real Buddhist" gets lost through repeated misperformance and misinterpretation of doctrine in the field. In this case, although the 969 Movement has less support than democracy in Myanmar, they are backed by the nationalist government that empowers them to continue to urge this violence against the Rohingya and despite their public claims of preserving Buddhism and promoting its ideals. This resonates with Ninian Smart's dimensional approach where the plural determinants are regulated by functional reciprocation (Smart 1996). All acting agents are affected by the same damaging factors of oppression and tyranny.

The plausibility of the nationalist framework is based in the memories of living people, some of whom endured both the oppressive junta regime and British colonization. 
The 969 emblem, monastic robes and symbols of government support denote power that encourages violence, despite its disingenuous statement of intending to encourage only defense. According to Bourdieu (1977, 21), the privation of opposition, in this case to the 969 Movement, encourages their own absolute ideals of what is perceived as heroic efforts. The 969 Movement has a following of at least 2 million (Walton and Hayward 2014, 19). In linking some historical Buddhist values to a xenophobic campaign, 969 has produced mnemonic principles that make the agents, specifically the 2,500 students who study under Wirathu, feel like they are executing an innate practice of their dhamma.

The fear of losing their identity as Buddhists creates an illusio ${ }^{21}$ of freedom that the population is willing to misrepresent Buddhist values of compassion and inaction in order to preserve the perceived threatened practice. According to Bourdieu, the leading field of all fields is the field of power in which the hierarchy of politics structures all the other fields (Bourdieu 1977, 73). The 969's politically inspired agenda exhibits this. In this case, Buddhism is perpetuating violence by endorsing absolutism. Simultaneously, Buddhism in Myanmar perpetuates misogyny. The result is a population that must choose between obeying military rule through an inauthentic existence, risking their lives by fighting back or end up stateless in bordering countries. Often this leaves women and children trapped in the grips of human trafficking as I witnessed with the refugees I worked with at Baan Unrak in Thailand. The symbolic structure of 969 contradicts the

${ }^{21}$ The commitment made to the misconception of reasonable behavior produced by societies is what Bourdieu calls illusio. That is, our behavior is not truly guided by our intention as much as our intention is created by society. 
nine attributes of the Buddha, the code of conduct of which moral restraint is the first rule.

The 969 logo is a stone pillar with four lions atop. This is a representation of the ancient emperor Asoka. Asoka is for Buddhists the representative of just war, responsible for the spread of Buddhism in South Asia. As the most revered king in Buddhist history, it is no wonder the 969 chose his emblem as their symbol. It is ironic that war was the initial methods of spreading the Buddhist teaching of nonviolence all over Asia. Today 969 uses violence supposedly to preserve Buddhism in Burma. However, Asoka was eventually haunted with guilt and it was only when he changed his ways to truly embrace the dhamma that Buddhism truly began to flourish.

Wirathu’s recurring narratives portraying the Burmese population as naïve and uneducated people demonstrate that he perceives the population as in need of guidance. This gives Wirathu a sense of possessing power over his agents, though he claims he has never told them to exercise violence. His sense of power also serves as an enforcer of his ethnocentrism, which Bourdieu says, is rooted through "unconscious acceptance of a restricted definition of economic interest” (Bourdieu 1977, 177 emph. in orig.). In this case, Wirathu's economic interest is the bourgeoning of Buddhism in Myanmar, hence his campaign to "buy Buddhist" that originally helped create the symbolic violence. Although national economics may play a peripheral role in his actions, he is not only enjoying personal economic luxuries, but also utilizing his symbolic power as a venerable Buddhist figure to achieve global religio-political fame.

Bourdieu also states that when the symbolic interest becomes more important to the leading agent than the actual capital, its pursuit becomes an irrational passion 
(Bourdieu 1977, 177). The leading agent then has unconscious goals, and will only find gratification when he has achieved complete dominion. Wirathu and the extremists alike claim to be pursuing goals that in reality are not achievable-an all Buddhist Myanmar, safe from all threat. They are playing for stakes that are unquantifiable and non-material, that may be essentially impossible, and therefore there will be no foreseeable sunset on the horizon of the exercise of their symbolic power-it will go on as long as his narrative is compelling to Myanmar's government, if not to a large number of its people.

According to Juergensmeyer (2000), symbolic capital, in this case the trust of the 969’s followers and nationalist population that Wirathu and 969 have secured, is devalued. This is especially more relevant at the moment due to the results of the recent elections, which favored the NLD. Wirathu and 969 are not the majority in Myanmar, although that is his ultimate goal. The symbolic power tends to overshadow reality when the strongest organ of power (the government) backs Wirathu. Therefore, he is experiencing a devaluation of authority extending past that of the social sphere, but it becomes personal as a loss of agency despite never really having the agency (Juergensmeyer 2000, 228). This is shown in his disregard for women having control of their own bodies and disbelief that they can attain bhikkhunī status like monks do. His loss of agency is also exercised in the way he gloats over Aung San Suu Kyi’s failed attempts to bring democracy to Myanmar. Wirathu feels compelled to provide ever more effort in his public performances in order to continue accruing symbolic capital. The perceived devaluation of Buddhism in Myanmar is made into a societal crisis. 
However, in the case of Theravada Buddhism among the nationalist Burmese and the 969 Movement, what embeds this devaluation may be the consistent fear present in the Pali canon of the end of the sangha that has been indoctrinated.

That's the way it is, Kassapa. When beings are degenerating and the true Dhamma is disappearing, there are more training rules and yet fewer monks established in final gnosis. There is no disappearance of the true Dhamma as long as a counterfeit of the true Dhamma has not arisen in the world, but there is the disappearance of the true Dhamma when a counterfeit of the true Dhamma has arisen in the world. Just as there is no disappearance of gold as long as a counterfeit of gold has not arisen in the world, but there is the disappearance of gold when a counterfeit of gold has arisen in the world, in the same way there is no disappearance of the true Dhamma as long as a counterfeit of the true Dhamma has not arisen in the world, but there is the disappearance of the true Dhamma when a counterfeit of the true Dhamma has arisen in the world (Bhikkhu Thanissaro 1994).

Gold here represents true value, but fool's gold or counterfeit gold represents what people will choose when it is presented like gold but achievable with less effort, and eventually they will not be able to recognize true gold. In this case, counterfeit gold refers to the inauthentic but simpler form of Buddhist practice (Saddhammapatirupaka 2005).

This metaphor applies to Wirathu and nationalists' use of phrases like "protection of women.” Women in Myanmar who succumb to these protection narratives and lead lives dependent on the decisions men make for them do not know what they have available to them outside of these options. Nationalists hold on to this safeguard of religion, race and women as if these three were all one and the same, all incapable of selfdefense. Women here lose their identity and individuality, as they become a thing like race and religion. Women in Myanmar are socialized to accept a lack of agency for nuns and simultaneously that women in general are subordinate, inherently evil and distracting to men. They are celebrated within this doctrine when they are mothers or fully ordained 
and enlightened bhikkhuniss. Both of these roles saya-leis cannot be and according to Wirathu, are almost always incapable of being. If they are poor they are denied access to education unless it is within the Buddhist practice itself. Where do these socioeconomically and religiously oppressed women have the chance to express their individuality? And how bad is it really from their perspectives? Is being a poor uneducated devout Buddhist woman dependent upon a man for protection better than any other options they are presented with in Myanmar? I cannot help but to feel like an ignorant First World brat feminist at times when performing my analysis. Still, speaking from a "person of color" perspective, gives me some credibility as a first-worlder, but also its theoretical underpinnings are such that it insists that not all women are the same. In turn, I feel it is my duty to support the women left clamoring for things they are denied as a form of solidarity.

\section{Conclusion}

One is exposed to the current battle for veracity in Myanmar through this bifurcated perception of history. This is evident in the different historical accounts given by Rohingya supporters and Burmese Buddhist nationalist in Chapter 3. There is an attachment to symbolic capital within the nationalist Burmese Buddhist community that prevents their intent from being scrutinized. That is, to eradicate the Rohingya population although it is disguised as protection of Buddhism and women. The justifications of protecting the sāsana are puzzling yet seemingly supported in Buddhist doctrine and by denying that they intend to incite violence. 
Protection of the sāsana has produced an axiom that constructs an avenue of escape from looming subordination to Islam, subordination currently non-existent. Yet fear of this subordination is embedded in their Buddhist culture; they draw upon Islamizations from the past to support their assertions. These fears were the product of colonialism and solidified the junta rule. While violating the Buddhist ideal of remaining in the present and veering away from the anxious thoughts of the future (in this case, a dreaded future), the nationalist Buddhists magnify and exaggerate those who are their victims. Simultaneously, they have become the oppressors to both the ethnic minority of Rohingyas and to women, who are portrayed as the very thing that these Buddhists fear becoming; weak, irrational and submissive.

Finally, Burmese Buddhist women are ambivalently treated as both valuable and in need of protection from the Muslim other and from themselves. Aside from Wirathu and other 969 subjects, even the most educated and independent informant I had, Daw Nang, was convinced that being a man is more fruitful than being a woman. I thoroughly enjoyed every second of my journey in Myanmar. As an American woman who was treated with the utmost respect and could afford all basic needs and even luxuries, it comes as no surprise that I am able to reflect on all the things I find wrong with the current situation among the Buddhist nationalists, Muslims and women. After analyzing the plight that it is to be a Buddhist woman in Myanmar as a secular feminist, I would say I agree that in this habitus, to be an ethnically Burman Buddhist man is the only choice even I would make if I was dealt that life.

It is important to add that during the development of this thesis several factors underwent change in Myanmar. The Union Solidarity and Development Party (USDP) 
lost to the National League of Democracy (NLD) by an overwhelming landslide despite the support of Ma Ba Tha and the 969. Although the NLD must tread carefully, changes toward Myanmar’s nationalist extremists are expected. According to Walton (2015), "Civil society, interfaith, youth and other groups have organized community networks dedicated to resisting inter-religious violence.” However, there is still worry for the continuance of Wirathu's growth. Inclusively, NLD leaders have also visited Wirathu on several occasions, including the NLD co-founder ex-general Tin Oo (Suu Kyi's Vice Chair), who was sent to visit Wirathu on the eve before elections in 2015 (Min 2015). These actions of support in addition to Suu Kyi's silence on the Rohingya do not seem to point toward a smooth democratization process for Myanmar anytime in the near future. 


\section{References}

Aung Thwin, Michael. 2009. “Of Monarchs, Monks, and Men: Religion and the State in Myanmar.” Asia Research Institute Working Paper No. 127, December. Accessed December 14, 2015. http://www.ari.nus.edu.sg/wps/wps09_127.pdf.

Aziz, Maha Hosain. 2015. “How ISIS Could Destroy Myanmar.” July 22. Accessed August 30, 2015. http://www.huffingtonpost.com/maha-hosain-aziz/how-isiscould-destroy-my_b_7810686.html

Bhikkhu Bodhi. 2005. “The happiness visible in this present life.” In In the Buddha's words: An anthology of discourses from the Pāli canon, Edited by Bhikkhu Bodhi, 139-141. Boston, Massachusetts: Wisdom Publications.

Bhikkhu Silacara. 1953. “Chapter 8: Making Known the Teaching.” In A Young People's Life of the Buddha. Access to Insight. Accessed April 5, 2015. http://www.accesstoinsight.org/lib/authors/silacara/youngpeoples.html

Bhikkhu Thanissaro, ed., trans. 1994. Kalama Sutta: To the Kalamas. Accessed January 14, 2015. http://www.accesstoinsight.org/tipitaka/an/an03/ an03.065.than.html.

Bischoff, Roger. 1995. Buddhism in Myanmar: A Short Story. Kandi: Buddhist Publication Society.

Bollee, W.B., trans. 1970. Kunala-Jataka. London: Pali Text Society.

Buchanan, Francis. 1799. “A Comparative Vocabulary of Some of the Languages Spoken in the Burma Empire.” Asiatic Researches, Issue 5: 219-40. Accessed September 2, 2014. http://eprints.soas.ac.uk/8050/1/ BuchananComparativeVocabulary.pdf

Bourdieu, Pierre. 1977. Outline of a Theory of Practice. Cambridge: Cambridge University Press.

Byrne, Jean. 2013. "Why I Am Not a Buddhist Feminist: A Critical Examination of 'Buddhist Feminism'” Feminist Theology, Volume 21 No. 2: 180-194. Accessed November 2, 2014. http://th.sagepub.com.ezproxy.fiu.edu/content/21/2/180.full.pdf+html

Candasiri. 2015. Interview by author. Mandalay, Myanmar. June-July.

Candavara, Ashin. 2015. Interview by author. Mandalay, Myanmar. June-July.

Chit Tin, Saya U. 1992. The Coming Buddha Ariya Metteya. Kandy: Buddhist Publication Society. Accessed December 10, 2015. https://what-buddhasaid.net/library/Wheels/wh381.pdf. 
Coclanis, Peter. 2013. “Terror in Burma: Buddhists vs. Muslims.” World Affairs 176: 25. November / December. Accessed Ocotber14, 2014.

http://www.worldaffairsjournal.org/article/terror-burma-buddhists-vs-muslims

Davis, Angela. 1981. Women, Race and Class. New York: Vintage Books.

Daw Nang. 2015. Interview by author. Mandalay, Myanmar. June-July.

Daw Zanaka Malini. 2015. Interview by author. Mandalay, Myanmar. June 24.

De Silva, Ranjani. 2004. "Reclaiming the Robe: Reviving the Bhikkhuni Order in Sri Lanka.” In Buddhist Women and Social Justice: Ideals, Challenges, and Achievements, edited by Karma Lekshe Tsomo, 134-135. Albany: State University of New York Press.

DVBTV English. 2013. "Wirathu Lashes Out at Time Magazine.” Interview: Ashin Wirathu and Thein Sein's Legal Representative. Accessed September 14, 2014. https://www.youtube.com/watch?v=LmDKjsMbaiM

Eleven Myanmar. 2015. “UN Special Rapporteur Yanghee Lee Meets Human Rights Activists, Media.” January 28. Accessed July 30, 2015. http://www.elevenmyanmar.com/local/un-special-rapporteur-yanghee-lee-meetshuman-rights-activists-media.

Falk, Nancy Auer. 2001. "The Case of the Vanishing Nuns: The Fruits of Ambivalence in Ancient Indian Buddhism.” In Unspoken Worlds: Women's Religious Lives, edited by Rita M. Gross and Nancy Auer Falk, 196-222. 3rd ed. Belmont, CA: Wadsworth Publications.

Faure, B. 2010. “Afterthoughts.” In Buddhist Warfare, edited by Michael Jerryson and Mark Juergensmeyer, 211 - 26. New York: Oxford University Press.

Ferrie, Jared, and Tun Aung Hla. 2015. "Myanmar Convicts Five over Fake Rape Claim that Sparked Riots.” Reuters. March 20. Accessed April 11, 2015. http://uk.reuters.com/article/uk-myanmar-convictionidUKKBN0MG11820150320

Fuller, Paul. 2015. “Sitagu Sayadaw 'Unconditionally’ Condemns Violence against Muslims in Burma.” Paul Fuller Buddhist Studies Blog, January 2. Accessed August 21, 2015. https://drpaulfuller.wordpress.com/category/ashin-nyanissara/.

Fytche, Albert. 1878. Burma Past and Present. Vol. 2. London: C. Kegan Paul \& Co.

Galache, Carlos Sardina. 2013. "Who Are the Monks Behind Burma’s '969’ Campaign?” Democratic Voice of Burma, May 10. Accessed April 12, 2015. 
http://www.dvb.no/news/ features-news/the-monks-behind-burma\%E2\%80\%99s\%E2\%80\%9C969 \%E2\%80\%9Dmovement-2/28079

Gier, Nicholas F. 2014. The Origins of Religious Violence: An Asian Perspective. London: Lexington Books.

Gombrich, Richard. 1971. Precept and Practice: Traditional Buddhism in the Rural Highlands of Ceylon. Oxford: Clarendon Press.

Green, Paula. 2014. "Transforming Conflict, Transforming Ourselves: Buddhism and Social Liberation.” In Buddhist Women and Social Justice: Ideals, Challenges, and Achievements, edited by Karma Lekshe Tsomo, 73-88. Albany: State University of New York Press.

Harriden, Jessica. 2012. The Authority of Influence: Women and Power in Burmese History. Honolulu: University of Hawaii Press.

Harvey, Peter. 2000. An introduction to Buddhist ethics: foundations, values, and issues. Cambridge, UK: Cambridge University Press.

Horner, I. B. 1952. Cullavagga. Repr. ed. Oxford: Pali Text Society.

Human Rights Watch. 2012. "The Government Could Have Stopped This: Sectarian Violence and Ensuing Abuses in Burma's Arakan State.” Accessed 14 August 2012. http://www.unhcr.org/refworld/pdfid/50211c9a2.pdf.

. 2013. "All You Can do is Pray: Crimes Against Humanity and Ethnic Cleansing of Rohingya Muslims In Burma’s Arakan State.” Accessed January 28, 2015. http://www.hrw.org/sites/default/files/reports/ burma0413webwcover_0.pdf.

— . 2015. "Burma: Reject Discriminatory Marriage Bill.” Last modified July 9, 2015. Accessed July 19, 2015. https://www.hrw.org/news/2015/07/09/burmareject-discriminatory-marriage-bill.

Inside Burma [Motion picture]. 1997. Bullfrog Films.

International Crisis Group. 2013. "The Dark Side of Transition: Violence Against Muslims in Myanmar.” Asia Report No. 251. Accessed April 18, 2015. http://www.crisisgroup. org/ /media/Files/asia/south-east-asia/burmamyanmar/251-the-dark-side- of-transition-violence-against-muslims-in-myanmar.

Jerryson, Michael K. 2010. “Introduction.” In Buddhist Warfare, edited by Mark Juergensmeyer and Michael K. Jerryson, 3-16. New York: Oxford University Press. 
- 2011. Buddhist Fury: Religion and Violence in Southern Thailand. Oxford: Oxford University Press.

—. 2013. "Buddhist Traditions and Violence" In The Oxford Handbook of Religion and Violence, edited by Mark Juergensmeyer, Margo Kitts and and Michael Jerryson, 41-66. New York: Oxford University Press.

. 2015. “The Rise of Militant Monks.” Lion’s Roar, August 23. Accessed October 12, 2015. http://www.lionsroar.com/the-rise-of-militant-monks/.

Juergensmeyer, M. 2000. Terror in the Mind of God: The Global Rise of Religious Violence. Berkeley: University of California Press.

Kawanami, Hiroko. 2013. Renunciation and Empowerment of Buddhist Nuns in Myanmar-Burma Building a Community of Female Faithful. Leiden: Brill.

Keyes, Charles F. 1983. "Merit-Transference in Kammic Theory of Popular Theravāda Buddhism." In Karma an Anthropological Inquiry, edited by Charles F. Keyes and E. Valentine Daniel, 261-285. Berkeley: University of California Press.

Khuankaew, Ouyporn. 2007. "Buddhism and Violence against Women.” In Violence against Women in Contemporary World Religions: Roots and Cures, edited by Daniel C. Maguire and Sa'diyya Shaikh, 174-191. Cleveland: Pilgrim.

Leider, Jacques P. 2008. "Forging Buddhist Credentials as a Tool of Legitimacy and Ethnic Identity: A Study of Arakan's Subjection in Nineteenth-Century Burma." Journal of the Economic ad Social History of the Orient Vol. 51 No. 3. http://www.jstor.org.ezproxy.fiu.edu/stable/pdf/ 25165255.pdf?acceptTC=true

LeVine, Sarah. 2004. "Dharma Education for Women in the Theravada Buddhist Community of Nepal." In Buddhist Women and Social Justice: Ideals, Challenges, and Achievements, edited by Karma Lekshe Tsomo, 137-154. Albany: State University of New York.

Lindquist, Alan C. 1979. "Report on the 1978-79 Bangladesh Refugee Relief Operation” Assessed on December 13 2015. http://www.ibiblio.org/obl/docs/ LINDQUIST_REPORT.htm

Marshall, Andrew. 2013. "Special Report: Myanmar gives official blessing to antiMuslim monks” Reuters. June 27. Accessed Ocotber14, 2014. http://www.reuters.com/article/us-myanmar-969-specialreportidUSBRE95Q04720130627

Maber, Elizabeth 2014. (In)Equality and action: the role of women's training initiatives in promoting women's leadership opportunities in Myanmar. Gender and 
Development. 141-156. Accessed November 11, 2015

http://www.themimu.info/sites/themimu.info/files/documents/Article_Gender_an d_Development_21Mar2014.pdf

Mahmood, Saba. 2012. Politics of Piety: The Islamic Revival and the Feminist Subject. Princeton: Princeton University Press.

Mantra of Rage [Motion picture]. 2013. Interview of Ashin Wirathu.

Min, Aung Kyaw. 2015. “NLD patron meets prominent monks.” Accessed February 20, 2016. http://www.mmtimes.com/index.php/national-news/16792-nld-patronmeets-prominent-monks.html

Myint-U, Thant. 2006. The River of Lost Footsteps: A Personal History of Burma. New York: Farrar, Straus and Giroux.

Nemoto, Kei. n.d. “The Rohingya Issue: A Thorny Obstacle between Burma (Myanmar) and Bangladesh.” Burma Library. Accessed July 1, 2013.

http://www.burmalibrary.org/docs14/Kei_Nemoto-Rohingya.pdf

Oxford Burma Alliance. 2013. “1988 Uprising and 1990 Election.” http://www.oxfordburmaalliance.org/1988-uprising--1990-elections.html.

Panna Jota. 2015. Interview by author. Mandalay, Myanmar. June-July.

Perera, H.R. 1988. Buddhism in Sri Lanka: A Short History. Buddhist Publication Society: Kandy. Accessed December 15, 2015. http://www.buddhanet.net/ pdf_file/bud-srilanka.pdf

Poling, Gregory. 2014. “Separating Fact from Fiction about Myanmar’s Rohingya.” Accessed April 20, 2015. http://csis.org/publication/separating-fact-fiction-aboutmyanmars-rohingya

Pruitt, William, and Kenneth Roy Norman. 2001. The Pātimokkha. Oxford: The Pali Text Society.

Puntarigvivat, Tavivat. 2001. “A Thai Buddhist Perspective.” In What Men Owe to Women: Men's Voices from World Religions, edited by John C. Raines and Daniel C. Maguire, 212-37. Albany: State University of New York.

Satha-Anand, Suwanna. "Buddhism on Sexuality and Enlightenment." Good Sex: Feminist Perspectives from the World's Religions, edited by Patricia B. Jung, Mary E. Hunt and Radhika Balakrishnan, 113-124. Piscataway, NJ: Rutgers University Press. 
Schiavenza, Matt. 2014. "President Obama Is in Burma—or Is It Myanmar?” November 13. Accessed April 3, 2015. http://www.theatlantic.com/ international/archive/2014/11/president-obama-is-in-burma-or-is-itmyanmar/382751

Schober, Juliane. 2007. "Buddhism, Violence and the State in Burma (Myanmar) and Sri Lanka." In Religion and Conflict in South and Southeast Asia Disrupting Violence, edited by Linell E. Cady and Sheldon W. Simon, 58-61. London: Routledge.

Smart, Ninian. 1996. Dimensions of the Sacred: An Anatomy of the World's Beliefs. Berkeley: University of California Press.

Sponberg, Alan, and Jose Ignacio Cabezón, eds. 1992. Buddhism, Sexuality, and Gender. Albany: State University of New York Press.

Swartz, Henry, and Nan Htoo San. 2014. "Burma Army ‘Raped Over 100 Women’ Since 2010.” Karen News. Accessed April 26, 2014. http://karennews.org/ 2014/01/burma-army-using-rape-as-a-weapon-of-war.html

Taylor, Robert H. 2009. The State in Myanmar. Honolulu: University of Hawaii Press.

Than, Soe and Aung, Ko Ko. 2015. "Ashin Wirathu: Myanmar and its Vitriolic Monk.” Accessed April 3, 2015. http://www.bbc.com/news/world-asia-30930997

Tin Aung Kyaw. 2013. "Buddhist Monk Wirathu Leads Violent National Campaign Against Myanmar's Muslims” Accessed August 25, 2015. http://www.huffingtonpost.com/burma-journal/buddhist-monk-wirathulea_b_3481807.html

United Nations. 1976. "International Covenant on Civil and Political Rights (ICCPR). Adopted by the General Assembly of the United Nations on 19 December 1966." Accessed November 28, 2014. https://treaties.un.org/doc/Publication/ UNTS/Volume 999/volume-999-I-14668-English.pdf.

Walton, Matthew. 2015. "The post-election future of Buddhist nationalism in Myanmar" Accessed January 28, 2016. http://www.eastasiaforum.org/2015/11/19/the-postelection-future-of-buddhist-nationalism-in-myanmar/

Walton, Matthew, and Susan Hayward. 2014. Contesting Buddhist Narratives: Democratization, Nationalism and Communal Violence in Myanmar. Honolulu, Hawaii: East West Center. 
War, Khine Mya. 2003. Criticizing the Falsification of the History Written by the Bengali Immigrants who were the Descendants of the Chittagonians using the Name Rohingya under a False Name of Human Rights. Tokyo: Khaing Thou.

Win Naung Toe. 2015. "Myanmar’s Parliament Approves Controversial Interfaith Marriage Law.” Accessed August 3, 2015. http://www.rfa.org/english/news/myanmar/parliament-approves-controversialinterfaith-marriage-law-07072015152051.html

Win Tin. 2014. Amending 59(f) will allow foreigners to exploit 'simple' Burmese, says Wirathu. Accessed November 18, 2014. http://www.youtube.com/ watch?v=MjIceTf5_o0

Wirathu, Ashin. 2015. Interview by author. Mandalay, Myanmar. June 26.

Yegar, Moshe. 2002. Between Integration and Secession The Muslim Communities of the Southern Philippines, Southern Thailand, and Western Burma/Myanmar. Lexington Books: Lanham. Accessed December 15, 2014. http://www.networkmyanmar.org/images/stories/PDF18/Yegar-2002.pdf

Zarni, Maung. 2014. “Ex-General Khin Nyunt says, ‘Muslims from our country Myanmar have been fleeing to Bangladesh' (not Bengali coming into Myanmar from Bangladesh)” Accessed August 25, 2015. http://www.maungzarni.net/2014/04/ex-general-khin-nyunt-says-muslimsfrom.html

—. 2016. Interview by GfbV. Geneva, Switzerland. March 24. https://soundcloud.com/gfbv/maung-zarni-about-his-activism-on-behalf-of-therohingya

Zarni, Maung and Alice Cowley. 2014. "The Slow Burning Genocide of Myanmar's Rohingya.” Pacific Rim Law and Policy Journal 23, no. 3: 682-752. Accessed March 25, 2015. http://www.rohingyamassacre.com/wpcontent/uploads/2014/08/233346421-The-Slow-Burning-Genocide-Of-Myanmars-Rohingya.pdf 